GUSTAVO POLLETTINI MARCOS

\title{
DESENVOLVIMENTO DE UM SISTEMA DE TEXTURIZAÇÃO PARA REBOLOS DE CBN VITRIFICADO BASEADO EM ANÁLISE MODAL
}

São Carlos

2018 

GUSTAVO POLLETTINI MARCOS

\title{
DESENVOLVIMENTO DE UM SISTEMA DE TEXTURIZAÇÃO PARA REBOLOS DE CBN VITRIFICADO BASEADO EM ANÁLISE MODAL
}

\author{
Dissertação apresentada à Escola \\ de Engenharia de São Carlos da \\ Universidade de São Paulo, como \\ requisito para a obtenção do Título de \\ Mestre em Engenharia de Produção. \\ Área de concentração: Processos e \\ Gestão de Operações - Processos \\ Avançados de Manufatura e \\ Sustentabilidade
}

Orientador: Prof. Eraldo Jannone da Silva

São Carlos 


\begin{abstract}
AUTORIZO A REPRODUÇÃO TOTAL OU PARCIAL DESTE TRABALHO, POR QUALQUER MEIO CONVENCIONAL OU ELETRÔNICO, PARA FINS DE ESTUDO E PESQUISA, DESDE QUE CITADA A FONTE.
\end{abstract}

Ficha catalográfica elaborada pela Biblioteca Prof. Dr. Sérgio Rodrigues Fontes da EESC/USP com os dados inseridos pelo(a) autor(a).

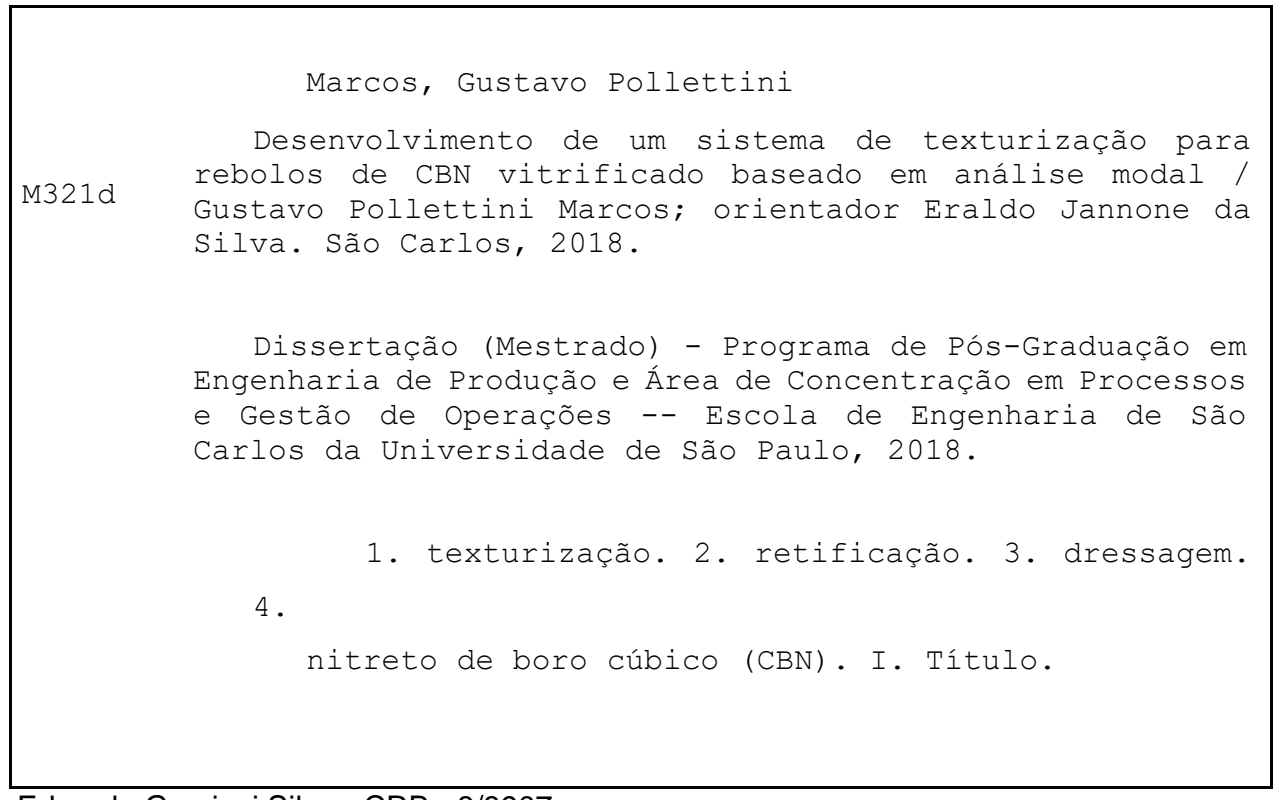

Eduardo Graziosi Silva - CRB - 8/8907 


\section{FOLHA DE JULGAMENTO}

Candidalo: Engenheiro GUSTAVO POLLETINI MARCOS.

Título da dissertação: "Desenvolvimento de um sistema de lexturização para rebolos de CBN vitrificado baseodo em análise modal".

Data da defesa: 03/07/2018.

Comissc̄o Julgadora:

Resultado:

Prot. Associado Eraldo Jannone da Sllva

(Orientador)

APROVADO

(Escola de Engenhario de Säo Carlos/EESC)

Prof. Dr. Carlos Eiji Hirata Ventura

(Universidade Federal de São Carlos/UFSCar)

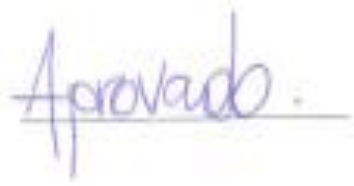

Prof. Dr. Anselmo Eduardo Diniz

APROV ADO

(Universidade Estadual de Campinas/UNICAMP)

Coordenador do Programa de Pós-Graduação em Engenharia de Produção:

Prot. Associado Aldo Roberto Ometto

Presidente da Comissâo de Pós-Graduação:

Prof, Associado Luís Fernando Costa Alberto 

DEDICATÓRIA

Aos meus pais, Edilson e Fátima, e meu irmão Leonardo. 



\section{AGRADECIMENTOS}

Ao Prof. Dr. Eraldo Jannone da Silva. pela oportunidade de trabalhar nesse projeto, e pela orientação durante todo o projeto.

Ao Prof. Titular João Fernando Gomes de Oliveira, pela coorientação, por todas as discussões sobre o projeto, experimentos e resultados.

Ao Prof. Titular Reginaldo Teixeira Coelho, por sempre estar disposto ajudar dentro do LAPRAS.

Ao Dr. Alex Camilli Bottene. pela amizade, por ter me incentivado por praticamente todo o período da pós-graduação, além de me auxiliar na realização do trabalho.

A CAPES - Fundação Coordenação de Aperfeiçoamento de Pessoal de Nível Superior, pela concessão da bolsa de mestrado.

Aos colegas do NUMA, que proporcionaram um ambiente de trabalho descontraído, facilitando o desenvolvimento desse trabalho.

Ao meu tio, Luís Fonseca Galli, por me incentivar e me apresentar a este projeto.

Ao departamento de pesquisa e desenvolvimento da empresa thyssenkrup Metalúrgica Campo Limpo Paulista, parceiros industriais do projeto. 



\title{
RESUMO
}

\author{
MARCOS, G. P. DESENVOLVIMENTO DE UM SISTEMA DE \\ TEXTURIZAÇÃO PARA REBOLOS DE CBN VITRIFICADO BASEADO EM \\ ANÁLISE MODAL. 2018. $71 \mathrm{f}$. Dissertação (Mestrado) - Escola de Engenharia de \\ São Carlos, Universidade de São Paulo, São Carlos, 2018.
}

\begin{abstract}
Superfícies funcionais dependem do controle das características das superfícies de um material para obter-se um desempenho funcional desejado. Essas superfícies têm importância em diversas áreas na engenharia, como: eletrônica, ótica, energia e tribologia. No campo da tribologia, uma aplicação é em virabrequins. A funcionalização da superfície adiciona micro cavidades que diminuem o atrito e aumentam as forças de sustentação do virabrequim. Para isso, essas cavidades possuem uma geometria específica, uma microrampa. Devido a essa forma especial, a fabricação dessas microrampas é complexa, já tendo sido alcançada empregando a metodologia de texturização com rebolos padronizados. Essa metodologia consiste na inscrição de padrões geométricos no rebolo durante a dressagem, posteriormente transferidos para a peça. Como a indústria moderna utiliza rebolos de CBN de ligante vitrificado para a retificação de virabrequins, a metodologia de texturização supracitada deve ser aplicável a esse ferramental. Esse trabalho descreve o desenvolvimento de uma unidade de dressagem capaz de inscrever padrões geométricos em rebolos de CBN vitrificados, sendo seu projeto baseado em análise modal. O trabalho apresenta as restrições de projeto, conceitos de solução, simulações dinâmicas e modelagem do processo de texturização. Para maximizar a resposta dinâmica, a unidade foi projetada para operar próxima de sua frequência natural. A unidade projetada é capaz de inscrever padrões geométricos no rebolo utilizando um disco dressador rotativo, e as texturas das peças produzidas com esse rebolo padronizado apresentam boa precisão geométrica para a aplicação em virabrequins.
\end{abstract}

Palavras-chave: texturização, retificação, dressagem, nitreto de boro cúbico (CBN). 



\section{ABSTRACT}

MARCOS, G. P. DEVELOPMENT OF A PATTERNING SYSTEM FOR VITRIFIED CBN WHEELS BASED ON MODAL ANALYSIS. 2018. $71 \mathrm{f}$. Dissertação (Mestrado) - Escola de Engenharia de São Carlos, Universidade de São Paulo, São Carlos, 2018.

Engineered surfaces rely on the control of the surface characteristics of a material to achieve a desired functional performance. These functional surfaces are important in several areas of engineering, such as: electronics, optics, energy and tribology. On tribology field, an application is in crankshafts. The surface functionalization is achieved by adding micro-cavities that reduce friction and increase crankshaft lift forces. These cavities have a specific geometry, called microramp. Due to this special geometry, manufacturing microramps is a complex process, having been achieved using the methodology of texturizing via grinding. This methodology consists in the inscription of geometric patterns in the grinding wheel during the dressing operation, later transferred to the piece. As the modern industry uses vitrified CBN grinding wheels for crankshaft grinding, the texturing methodology should be applicable to this tool. This work describes the development of a dressing unit capable of inscribing geometric patterns in vitrified CBN grinding wheels, having its design based on modal analysis. The work presents the design constraints, solution concepts, dynamic simulations and modeling of the texturing process. To maximize dynamic response, the unit is designed to operate near its natural frequency. The designed unit can inscribe geometric patterns on the grinding wheel using a rotating dressing disc, and the textures of the parts produced have good geometric precision for crankshaft applications.

Keywords: texturization, grinding, dressing, cubic boron nitride (CBN). 



\section{LISTA DE FIGURAS}

Figura 2.1 - Número de pesquisas globais sobre superfícies funcionais. .8

Figura 2.2 - Texturas em forma de calota esférica (a) e ponta de flecha (b) .............12

Figura 2.3 - Perfil genérico da textura desenvolvida pela thyssenkrup. 13

Figura 2.4 - Texturas obtidas com rebolo perfilado por Stépien e Szafarczyk em (1989).

Figura 2.5 - Experimento de texturização com rebolo engenheirado. 15

Figura 2.6 - Esquema do sistema de texturização utilizado por Oliveira, Bottene e França (2010). 17

Figura 2.7 - Peças texturizada por rebolos dinamicamente dressados. 18

Figura 2.8 - Estratégias para controle de rugosidade de peças texturizadas. 19

Figura 2.9 - Sistema de texturização de rebolos com atuador piezoelétrico. 19

Figura 2.10 - Comparativo de medida de circularidade e circularidade simulada. ...20

Figura 3.1 - Efeito da razão de esmagamento na rugosidade do rebolo. .23

Figura 3.2 - Dimensões típicas de uma textura em forma de dimple. .25

Figura 3.3 - Textura de interesse (microrampa). .26

Figura 3.4 - Características de perfil da microrampa. .26

Figura 3.5 - Condições geométricas de contato entre disco dressador e rebolo.......28

Figura 4.1 - Retificadora CNC Zema Numerika G-800-HS. 31

Figura 4.2 - Painel de operação e instrumentos da retificadora. 32

Figura 4.3 - Desenho esquemático da peça utilizada para os testes de retificação 33

Figura 4.4 - Conceito de unidade dressadora movida por mesa posicionadora. 34

Figura 4.5 - Esquema da modificação da unidade dressadora. 35

Figura 4.6 - Unidade dressadora proposta. .36

Figura 4.7 - Curva de resposta do amplificador E-481. 37

Figura 4.8 - Variação do comprimento de contato entre disco e rebolo para diferentes relações de velocidade, granulometria e profundidade de dressagem. .38 Figura 4.9 - Primeiro modo de vibração do conjunto, no plano YZ, condição de base fixada.

Figura 4.10 - Primeiro modo de vibração do conjunto, no plano XZ, condição de base fixada. 
Figura 4.11 - Resultado da simulação da estrutura submetida a uma força de 1250N.

Figura 4.12 - Imagem do sistema montado na retificadora.

Figura 4.13 - Imagem do sistema instrumentado para ensaios de resposta em frequência. 44

Figura 4.14 - Montagem da instrumentação para o teste de impacto no rebolo. 44

Figura 4.15 - Comportamento experimental da função de resposta em frequência da unidade dressadora. 46

Figura 4.16 - FRF do teste de impacto realizado na unidade dressadora. 46

Figura 4.17 - FRF do teste de impacto no rebolo de CBN. 47

Figura 4.18 - FRF dos ensaios de impacto no rebolo e na unidade dressadora. 48

Figura 4.19 - FRF da unidade dressadora durante operação, em contato total com o rebolo. 48

Figura 4.20 - FRF do atuador e sua estrutura protetora. 49

Figura 4.21 - Esquema da estratégia de texturização do rebolo por múltiplos passes. 51

Figura 4.22 - Medição de circularidade da peça texturizada com rampa de proporção $1: 5$ e profundidade de $12 \mu \mathrm{m}$. 53

Figura 5.1. - Profundidade da textura medida na peça retificada para diferentes proporções de rampa e FRF do comportamento do sistema. 56

Figura 5.2 - Perfil da microrampa gerada, simulada e medida. 58

Figura 5.3 - Três perfis consecutivos de microrampa gerada, simulada e medida referentes a um dressador de ponta única com bd de 0,6 $\mu \mathrm{m}$. 58

Figura 5.4 - Circularidade medida e simulada para a rampa de 1:5. 59

Figura 5.5 - Peça texturizada preparada para melhor visualização das microrampas.

Figura 5.6 - Medida na direção axial do perfil da microrampa de 1:5 em padrão xadrez 60

Figura 5.7 - Potenciais pontos de perda de energia no sistema de texturização...... 61 


\section{LISTA DE QUADROS}

Quadro 2-1 - Propriedades funcionais e domínio de aplicações de superfícies texturizadas.

Quadro 2-2 - Técnicas de remoção de material para fabricação de superfícies funcionais. 10

Quadro 4-1 - Simulação de força de aplicação e deslocamento máximo do disco na direção Z. 42

Quadro 4-2 - Testes para calibração do sistema. .53

Quadro 5-1 - Proporções e frequências de geração do sinal da microrampa. .56 


\section{SUMÁRIO}

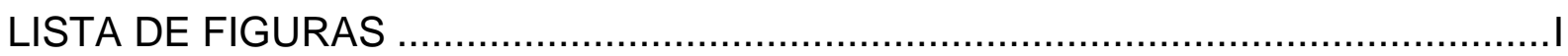

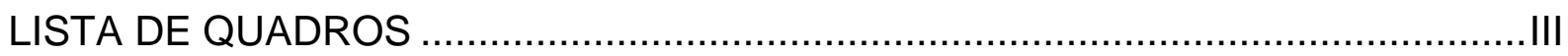

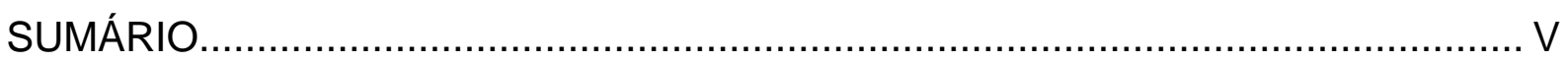

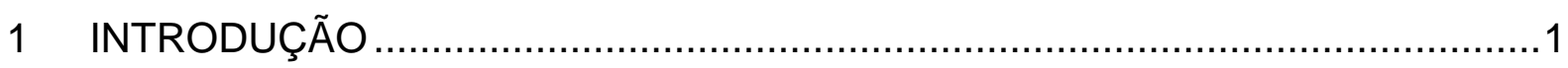

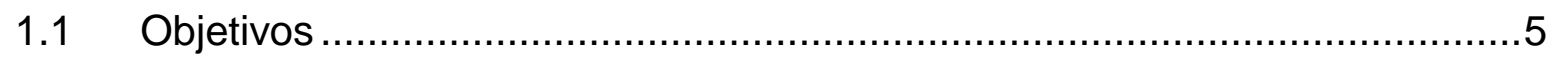

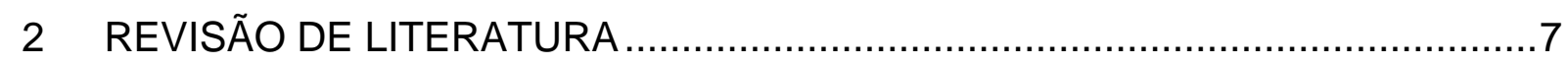

2.1 Superfícies funcionais para o uso em mancais hidrodinâmicos ..................7

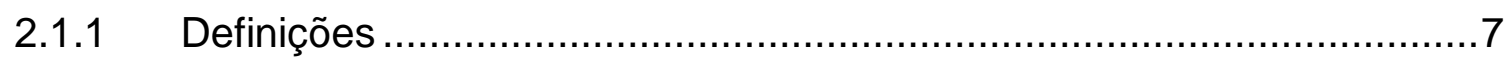

2.1.2 Classificação dos processos para produção de superfícies funcionais .9

2.1.3 Aplicações de superfícies funcionais em mancais hidrodinâmicos ......12

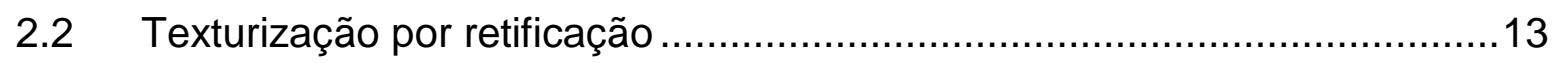

3 REQUERIMENTOS DE PROJETO PARA O DESENVOLVIMENTO DE UM SISTEMA DE TEXTURIZAÇÃO PARA REBOLOS DE CBN COM LIGANTE

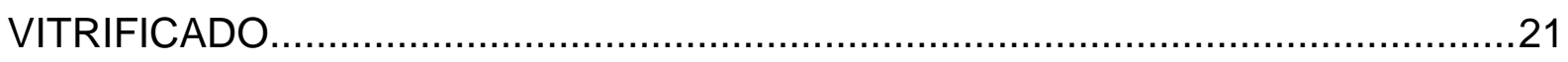

3.1 Particularidades do processo de dressagem com discos rotativos para rebolos de CBN de ligante vitrificado ....................................................22

3.2 Conceito do dispositivo a ser desenvolvido .................................... 24

3.2.1 Restrições impostas pela geometria a ser produzida ........................25

3.2.2 Restrições geométricas da interação rebolo e disco dressador ...........27

3.2.3 Restrições construtivas do dispositivo ........................................29

3.3 Projeto baseado em análise modal para maximização do desempenho funcional do sistema a ser desenvolvido .............................................29

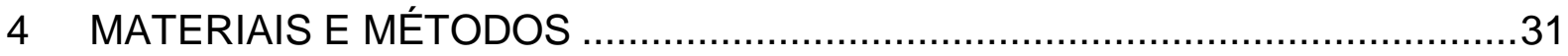

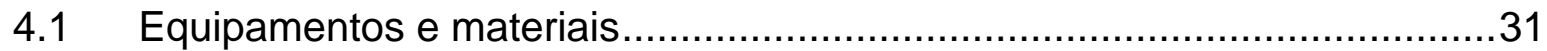

4.2 Projeto inicial do sistema de dressagem para inscrição de padrões

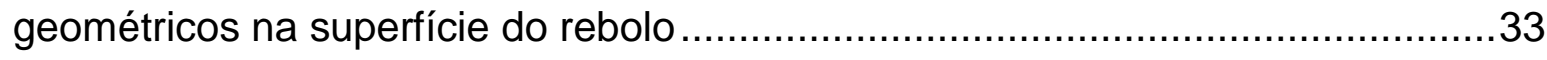




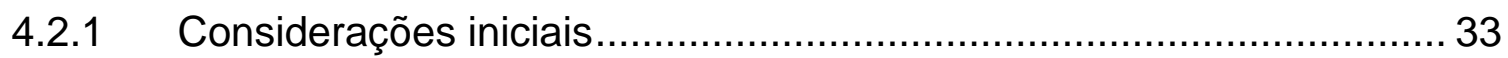

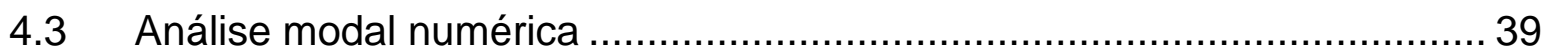

4.4 Análise modal experimental ............................................................. 43

4.4.1 Instrumentação do sistema de dressagem .................................... 43

4.5 Testes experimentais de texturização por retificação ............................50

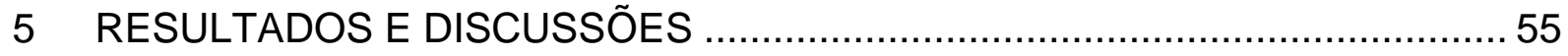

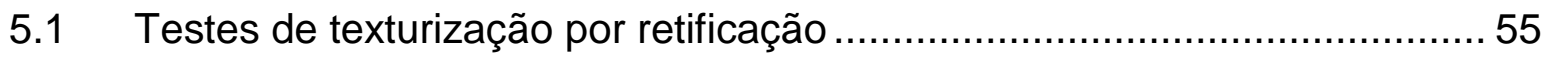

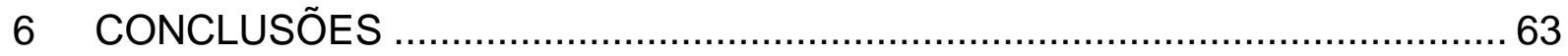

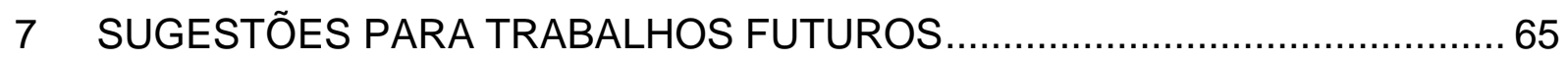

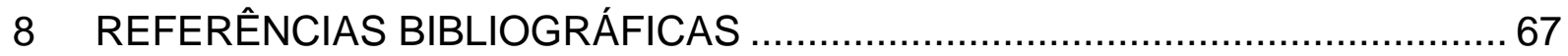




\section{INTRODUÇÃO}

Atribui-se o nome de superfície funcional à face de objetos construída com padrões que otimizam sua interação com o meio em que é aplicado. Alterando a microestrutura das superfícies, pode-se modificar propriedades físicas, químicas e óticas de um material (EVANS; BRYAN, 1999). Essas regiões projetadas não se relacionam com as maneiras tradicionais de caracterização de acabamentos superficiais, como os parâmetros de rugosidade, já que a estrutura da superfície é padronizada, texturizada, não uma distribuição aleatória de picos e vales. Bruzzone et al. (2008), traz uma revisão atualizada sobre o tema, expondo um panorama do desempenho das superfícies funcionais e dos processos de fabricação dessas texturas.

Superfícies funcionais têm importância em diversas áreas, com aplicações em eletrônica (WANG et al., 2015), aplicações óticas (CHO et al., 2013), na tribologia (IBATAN; UDDIN; CHOWDHURY, 2015) e também na saúde (ZHANG et al., 2015). O trabalho de BRAUN et al. (2014) investigou a redução de atrito causada pela texturização de $10 \%$ de um disco, parte integrante de um aparelho chamado de tribômetro de pino sobre disco. As texturas aplicadas foram dimples, orifícios de forma circular, e os resultados dos testes tribológicos alcançaram uma redução da ordem de $80 \%$ do atrito.

Diversas técnicas vêm sendo desenvolvidas para produzir tais superfícies. Bruzzone et al. (2008), as dividiu em quatro grandes grupos: os processos por adição de material, os de movimentação de material, auto-formação e remoção de material. Nos processos por remoção de material estão incluídas, principalmente, operações por gravura (etching), laser e usinagem.

A técnica de etching, remove material por meios químicos, produzindo texturas com alta precisão dimensional e acabamento. Entretanto, o processo necessita de ferramental específico, possui baixa produtividade e comparativo alto custo operacional em relação aos outros processos substrativos (COSTA; HUTCHINGS, 2007).

A texturização por pulsos laser também tem bom desempenho geométrico, caracterizando-se pelo elevado grau de precisão na remoção micrométrica de material 
da superfície. A aplicação por laser sublima o material e pode criar imperfeições nas bordas das texturas, sendo necessária uma operação de acabamento pós texturização. O processo de fabricação a laser não é tipicamente empregado na cadeia produtiva na indústria metal mecânica, exigindo uma etapa adicional na cadeia, além de ferramental extra. Esses custos associados, aliados à baixa produtividade, inviabilizam a utilização do laser para alta produção (ETSION, 2005).

A usinagem apresenta uma grande vantagem, pois muitas vezes já faz parte da cadeia produtiva da peça, o que exclui a necessidade da adição de um novo processo, bem como o investimento em novos equipamentos, ganhando-se em produtividade e reduzindo-se os custos.

A fabricação com ferramentas de geometria definida (torneamento e fresamento) apresenta uma limitação da textura gerada em função da dimensão da aresta de corte. Aliado a isso, a alta complexidade da formação de cavaco em escala micrométrica com as ferramentas de torneamento e fresamento dificultam a aplicação desses processos para a texturização. O trabalho de Denkena et al. (2010) mostra a texturização de peças pelo processo de torneamento para armazenamento de informações na superfície de peças.

No campo da usinagem pode-se destacar as técnicas que utilizam abrasivos, como: brunimento, lapidação, jateamento abrasivo e, especialmente, a retificação. $O$ processo de retificação é comumente empregado na indústria para garantir tolerâncias geométricas, dimensionais e acabamento de superfície. Outras qualidades são a alta produtividade e a facilidade de trabalhar com metais de elevada dureza, se comparado a processos de torneamento e fresamento. Por esses fatores, a obtenção de superfícies funcionais por retificação se mostra uma solução muito interessante. Para que a peça seja texturizada, deve-se criar o padrão desejado no rebolo e, posteriormente, transferi-lo para o produto durante a retificação.

Existem algumas formas já desenvolvidas para a obtenção de rebolos padronizados. Os grãos abrasivos podem ser depositados em posições predefinidas na estrutura do rebolo com extrema exatidão, o que gera texturas muito precisas. $O$ problema é o custo elevado, além da limitação a um único perfil por ferramenta. Aurich et al. (2003), mostra o processo da fabricação de um rebolo com grãos em posições 
definidas e, juntamente com Silva et al. (2017), mostra a aplicação de rebolos desse tipo para texturização de peças.

Padrões no rebolo também podem ser criados pela remoção de grãos por dressagem convencional (STȨPIEŃ, 2009) ou dressagem com laser (KHANGAR; DAHOTRE, 2005). Apesar da precisão e relativa flexibilidade, a geometria dos raios laser limita a forma das estruturas geradas. Ademais, as retificadoras não são equipadas com esses dispositivos, ou seja, essa opção requer um investimento adicional. Rabiey (2010) mostra um exemplo de rebolo de CBN vitrificado padronizado com furos cegos por aplicação de pulsos laser. Esses furos reduzem a área de contato do rebolo em $20 \%$, sendo este utilizado para testes de retificação a seco. Li e Axinte (2016) fizeram uma revisão sobre os estudos de rebolos padronizados, classificando e ordenando cronologicamente trabalhos que estudam o desenvolvimento desses rebolos engenheirados.

A opção que possibilita a maior variedade de texturas é a desenvolvida por Oliveira et al. (2010). Este método utiliza um dressador de ponta única tradicional, acionado por um dispositivo eletromecânico, fazendo com que a profundidade de dressagem seja dinamicamente variada durante a operação. Dessa forma, a superfície do rebolo é formada com o padrão desejado. A desvantagem dessa técnica em relação às outras é não ser aplicável em rebolos superabrasivos. Alguns superabrasivos possuem ligantes que não podem ser dressados, como o ligante metálico. Se o ligante for vitrificado, o rebolo superabrasivo pode ser dressado, porém, dressadores de ponta única se desgastam rapidamente nessas operações, tornando seu uso impraticável.

$\mathrm{Na}$ indústria, cada vez mais as operações de retificação estão migrando para a utilização de rebolos superabrasivos de nitreto de boro cúbico (CBN) com ligante vitrificado. Esse ferramental permite a prática de velocidades superiores, mantendo a qualidade geométrica, de forma e superficial sem causar danos térmicos às peças. Rebolos de CBN com ligante vitrificado podem ser dressados para condicionar sua superfície. Esse tipo de ligante também permite que, na mesma operação de dressagem, sejam feitas operações de perfilamento e avivamento. O perfilamento influencia na macrogeometria do rebolo, corrigindo erros de circularidade e podendo, se necessário, alterar seu perfil, tipicamente plano, adicionando raios ou ângulos. $O$ 
avivamento atua na microgeometria do rebolo, removendo o ligante para exposição dos grãos abrasivos.

A dressagem de rebolos de CBN vitrificado é impraticável por ferramentas estáticas, sejam compostas por conglomerados de diamantes ou de ponta única. Isso se deve ao alto desgaste imposto pelos duros grãos de CBN. Apesar de o diamante ter maior dureza que o CBN, vários grãos de CBN se chocam contra o dressador causando maior desgaste aos diamantes. Os dressadores recomendados são rotativos, discos ou rolos diamantados acionados por um motor. Esses dressadores rotativos possuem camadas de diamante em sua periferia. Assim, abundantes quantidades de grãos de diamante entram em contato com o rebolo, o que aumenta a vida útil do dressador (ROWE, 2014).

A versátil e produtiva técnica de texturização de rebolos por meio da dressagem dinâmica não pode ser aplicada a essas ferramentas de alto desempenho com os dressadores de ponta única. O enfoque desse trabalho é o estudo de uma solução para unir o alto rendimento da operação de retificação com rebolo de CBN com ligante vitrificado à flexibilidade da texturização por retificação.

A viabilização técnica esbarra em algumas dificuldades, como a necessidade de se movimentar, com precisão e agilidade, o pesado conjunto de disco diamantado e motor; a resposta desse sistema de dressagem, uma vez que as velocidades envolvidas são maiores do que quando se trabalha com rebolos convencionais; a elevada dureza dos grãos de CBN e do ligante vitrificado implicam em forças de dressagem mais intensas, principalmente pela necessidade de se variar a profundidade de dressagem durante essa operação.

Essa pesquisa faz parte de um projeto de parceria entre a thyssenkrupp Metalúrgica Campo Limpo LTDA e o Laboratório de Processos Avançados e Sustentabilidade (LAPRAS) - Escola de Engenharia de São Carlos (EESC) Universidade de São Paulo (USP). A thyssenkrupp estabeleceu um convênio com a USP e amparou o desenvolvimento desse trabalho. Ainda, há um contrato de propriedade intelectual entre a empresa e a Fundação para Incremento da Pesquisa e Aperfeiçoamento Industrial - FIPAI, representante da EESC-USP no convênio, que envolve futuras aplicações em produtos da empresa. 


\subsection{Objetivos}

O objetivo principal desta pesquisa é desenvolver uma unidade dressadora, mediante análise modal, capaz de padronizar um rebolo de CBN de ligante vitrificado. A padronização é baseada em geometrias pré-definidas para funcionalização associada à aplicação. $O$ processo requer identificar as restrições impostas pelo tipo de dressagem requerido e pela forma do padrão geométrico desejado. Com a unidade dressadora desenvolvida, faz-se necessário desenvolver uma estratégia para gerar o padrão no rebolo e, posteriormente, verificar a geometria do padrão inscrito. Há a necessidade de texturizar o diâmetro externo de uma peça cilíndrica metálica com o rebolo padronizado. A textura resultante na peça deve atender limites geométricos, forma e profundidade pré-estabelecidos. 


\section{REVISÃO DE LITERATURA}

\subsection{Superfícies funcionais para o uso em mancais hidrodinâmicos}

\subsubsection{Definições}

Os pesquisadores Evans e Bryan (1999) definiram que superfícies estruturadas (structured surfaces) são padrões especificamente projetados para garantir alguma função adicional a uma superfície. $O$ conjunto de técnicas especialmente desenvolvidas para manufatura de tais superfícies é chamado de engenharia de superfície (engineered surfaces) pelos mesmos autores (EVANS; BRYAN, 1999). Bruzzone et al. (2008) usa a mesma classificação, além disso, seu trabalho também expõe novas tecnologias de fabricação e as categoriza segundo suas aplicações. Os três grupos básicos são relativos a funções físicas, biológicas e tecnológicas. Os dois trabalhos supracitados compõem uma revisão das superfícies funcionais, apresentando métodos de fabricação, formas de medição e possíveis aplicações. Esses trabalhos têm grande influência no crescente interesse da comunidade para pesquisas nessa área.

Gropper; Wang e Harvey (2016) mostram os avanços relacionados às aplicações e projeto das texturas, creditando ao grupo de Etsion e aos resultados promissores de seu artigo de 1996 (A model for mechanical seals with regular microsurface structure) o crescimento das pesquisas na área. $O$ artigo de Etsion expõe a descoberta de um ganho de força de sustentação em selos mecânicos com texturas em formas de dimples hemisféricos na superfície de uma das extremidades acopladas. A Figura 2.1 mostra a evolução do número das pesquisas na área de texturização em contatos tribológicos, além de indicar que a maioria dos trabalhos é de cunho teórico (GROPPER; WANG; HARVEY, 2016). 
Figura 2.1 - Número de pesquisas globais sobre superfícies funcionais



Fonte: (GROPPER; WANG; HARVEY, 2016), adaptado pelo autor.

Moronuki (2016) faz uma revisão das aplicações de superfícies funcionais considerando a grandeza física envolvida, a função que exerce e as possíveis/reais aplicações. $O$ enfoque foi em trabalhos nos quais os projetos das texturas têm inspiração na natureza e nas superfícies biomimetizadas. $O$ artigo cita ainda casos efetivos de fabricação de superfícies bioinspiradas por processos industriais, que atingiram os resultados funcionais desejados. COBLAS et al. (2015) apresentam uma revisão similar, sem o enfoque em trabalhos com referências da natureza. O Quadro 2-1 sumariza a classificação de Coblas e colaboradores sobre as aplicações revisadas, mostrando a grande quantidade de aplicações que as superfícies funcionais podem ter, nos mais diversos campos da engenharia. 
Quadro 2-1 - Propriedades funcionais e domínio de aplicações de superfícies texturizadas.

\begin{tabular}{|c|c|c|}
\hline Domínio & Função & Aplicações \\
\hline Ótica & $\begin{array}{l}\text { Reflexão, difração, polarização, } \\
\text { absorção de luz, filtro }\end{array}$ & $\begin{array}{l}\text { Lentes Fresnel, sinalização reflexiva, filtros } \\
\text { de luz, espelhos específicos }\end{array}$ \\
\hline Acústica & Redução de ruído e vibração & Discos de freio \\
\hline Energia de superfícies & $\begin{array}{l}\text { Capilaridade, adesão, } \\
\text { molhabilidade }\end{array}$ & $\begin{array}{l}\text { Super-hidrofobia, super-olefobia, } \\
\text { superfícies auto-limpantes, adesão de } \\
\text { tintas, adesão de superfícies, separação } \\
\text { de óleo/água, superfície anti-adesão }\end{array}$ \\
\hline Mecânica & $\begin{array}{l}\text { Aumento de resistência a fadiga } \\
\text { e dureza, aumento de vida }\end{array}$ & $\begin{array}{l}\text { Disco rígido, fixação a vácuo, máquinas } \\
\text { para processos abrasivos (para corte, } \\
\text { polimento e marcação) }\end{array}$ \\
\hline Lubrificação & $\begin{array}{l}\text { Micro-mancais, aprisionamento } \\
\text { de partículas suspensas, } \\
\text { armazenamento de lubrificante, } \\
\text { redução de atrito e adesão, } \\
\text { melhoria de resistência ao } \\
\text { desgaste, formação de tribo- } \\
\text { filmes }\end{array}$ & $\begin{array}{l}\text { Mancais axiais, mancais radiais, selos } \\
\text { mecânicos e selos dinâmicos }\end{array}$ \\
\hline Hidrodinâmica & $\begin{array}{l}\text { Redução de arraste, nucleação } \\
\text { de bolhas }\end{array}$ & $\begin{array}{l}\text { Microfluídica (difusão, controle de fluído), } \\
\text { cravos de pneus, bolas de golf }\end{array}$ \\
\hline Bioengenharia & $\begin{array}{l}\text { Promover ou inibir absorção, } \\
\text { adesão ou crescimento celular }\end{array}$ & $\begin{array}{l}\text { Cultura de células, bio-MEMS, implantes, } \\
\text { adesão química. }\end{array}$ \\
\hline Termodinâmica & Transferência de calor & Mecanismos de pulverização e ebulição \\
\hline
\end{tabular}

Fonte: (COBLAS et al., 2015), adaptado pelo autor.

\subsubsection{Classificação dos processos para produção de superfícies funcionais}

O trabalho de Evans e Bryan (1999), propõe uma classificação dos processos de fabricação viáveis para a produção de superfícies funcionais. Tal classificação se tornou referência na área e foi aperfeiçoada com base nos avanços tecnológicos por Bruzzone et al. (2008), sendo adotada, de maneira geral, por outros autores. A classificação divide os processos em quatro grupos: adição de material; remoção de material; movimentação de material e formação por replicação.

As tecnologias de adição de material envolvem a deposição de uma cobertura sobre a superfície da peça. O local de aplicação deve ser cuidadosamente limpo, pois qualquer sujeira pode comprometer a função desejada. Os equipamentos de deposição são bem sofisticados, implicando em custo elevados.

Os processos de remoção de material serão mais amplamente abordados no decorrer do texto, mas, basicamente, geram superfícies funcionais subtraindo material da superfície da peça, criando pequenos sulcos. 
Processos de produção de superfícies funcionais por movimentação de material são realizados por deformações plásticas e redistribuição do material de algumas partes da superfície para outras, fato que limita sua aplicação a materiais dúcteis, como polímeros termoplásticos e certos metais.

As técnicas de replicação são bastante complexas. Nesse caso, as texturas são formadas por desgaste, em pontos específicos, do material da superfície da peça. Esse degaste pode se dar em decorrência do uso da peça, como em um mancal deslizante, onde um eixo gira na parte interna do mancal e o atrito desse movimento gera um desgaste. Um exemplo são peças fabricadas com pequenas áreas de maior dureza em meio a áreas de menor dureza, assim, o desgaste ocorre em diferentes velocidades em cada parte da peça, levando à formação de estruturas geométricas, formando as texturas.

Abdel-Aal (2016), traz uma revisão atualizada sobre os processos de fabricação. O Quadro 2-2 mostra o compilado dos métodos para os casos de remoção de material.

Quadro 2-2 - Técnicas de remoção de material para fabricação de superfícies funcionais.

\begin{tabular}{|c|c|c|}
\hline $\begin{array}{c}\text { Macro } \\
\text { classificação }\end{array}$ & Métodos & Processos \\
\hline \multirow{3}{*}{ Alta temperatura } & Laser & $\begin{array}{c}\text { Laser surface texturing (LST), } \\
\text { masked excimer laser, CNC } \\
\text { focused lasers, femto-second lasers. }\end{array}$ \\
\hline & $\begin{array}{l}\text { Usinagem por descargas } \\
\text { elétricas (EDM) }\end{array}$ & $\begin{array}{c}\text { Electrical discharge texturing (EDT), } \\
\text { micro EDM. }\end{array}$ \\
\hline & \multicolumn{2}{|c|}{ Ion bean texturing (IBT) } \\
\hline \multirow[b]{2}{*}{ Químico (etching) } & Métodos com uso de máscara & $\begin{array}{c}\text { Chemical texturing, electrochemical } \\
\text { texturing. }\end{array}$ \\
\hline & $\begin{array}{c}\text { Métodos sem necessidade de } \\
\text { máscara }\end{array}$ & $\begin{array}{l}\text { Self-assembling, masksless } \\
\text { electrochemical texturing, } \\
\text { anisotropic etching. }\end{array}$ \\
\hline \multirow{6}{*}{ Mecânico } & Usinagem CNC ultrassônica & \\
\hline & Brunimento & \\
\hline & Retificação & \\
\hline & Jatos abrasivos & \\
\hline & Micro usinagem & \\
\hline & Erosão com máscara & \\
\hline
\end{tabular}

Fonte: (ABDEL-AAL, 2016), adaptado pelo autor.

Da análise do Quadro 2-2, verifica-se um destaque natural para os processos de remoção de material, já que se refere às técnicas com maior tempo de 
desenvolvimento, principalmente se tratando dos métodos mecânicos. Algumas dessas técnicas já fazem parte da cadeia de manufatura dos produtos. Além disso, a fabricação por remoção de material tipicamente alia alta produtividade e alta qualidade de peças. O laser é uma das aplicações mais utilizadas. Consiste na emissão de pulsos ultracurtos de radiação ultravioleta. $O$ material submetido a esse calor derrete e evapora quase que imediatamente. O processo em si não é tão demorado, o problema é a possibilidade de gerar rebarbas, o que traz a necessidade de se fazer um pós-processamento. Com isso, o tempo de produção das peças aumenta, assim como os custos (VILHENA et al., 2009). Outra limitação se deve à falta de controle sobre a porção de material removida. A alta energia do processo sublima o material, assim não se tem controle sobre a rugosidade resultante.

Outra técnica bastante pesquisada é a de micro-usinagem, sendo exemplos de processos o micro fresamento e micro furação. Esses processos possibilitam grande controle sobre o acabamento, mas, assim como o laser, devido à precisão, ainda são métodos lentos e caros, apesar do desenvolvimento de novas estratégias de fabricação na área (MASUZAWA, 2000). A revisão de Chavoshi et al. (CHAVOSHI; GOEL; MORANTZ, 2017) afirma que, para atender às necessidades de tolerâncias apertadas e precisão de posicionamento dos processos de texturização, ainda são necessárias inovações na manufatura.

Os artigos que tratam do tema defendem que a escolha do melhor processo para fabricação depende da aplicação desejada e das precisões de forma e geometria que cada caso requer (ABDEL-AAL, 2016). Não há hegemonia de algum processo, o que rege sua escolha são os interesses e objetivos do projeto da superfície funcional. Moronuki (MORONUKI, 2016) cita que os projetistas de produtos e de processos precisam ter grande experiência na área de superfícies funcionais para conseguir aliar o processo de fabricação adequado para a textura desejada, uma vez que as texturas podem ser fabricadas por processos físicos ou químicos não tradicionais. 


\subsubsection{Aplicações de superfícies funcionais em mancais hidrodinâmicos}

Aplicações tribológicas representam uma grande área de pesquisa. Como mostra Abdel-Aal et al. (2016), vários estudos já foram realizados buscando reduções de atrito e desgaste em superfícies lubrificadas. Com isso, formas de texturas que têm como características o armazenamento de lubrificantes e retenção de partículas suspensas foram desenvolvidas, assim como critérios de projeto para essas estruturas (GROPPER; WANG; HARVEY, 2016). Geometrias em forma de calotas esféricas e elípticas, dimples (Figura 2.2 (a)), e formas de ponta de flecha, chevrons (Figura 2.2 (b)), apresentam os melhores resultados para essas aplicações (GACHOT et al., 2017).

Figura 2.2 - Texturas em forma de calota esférica (a) e ponta de flecha (b).
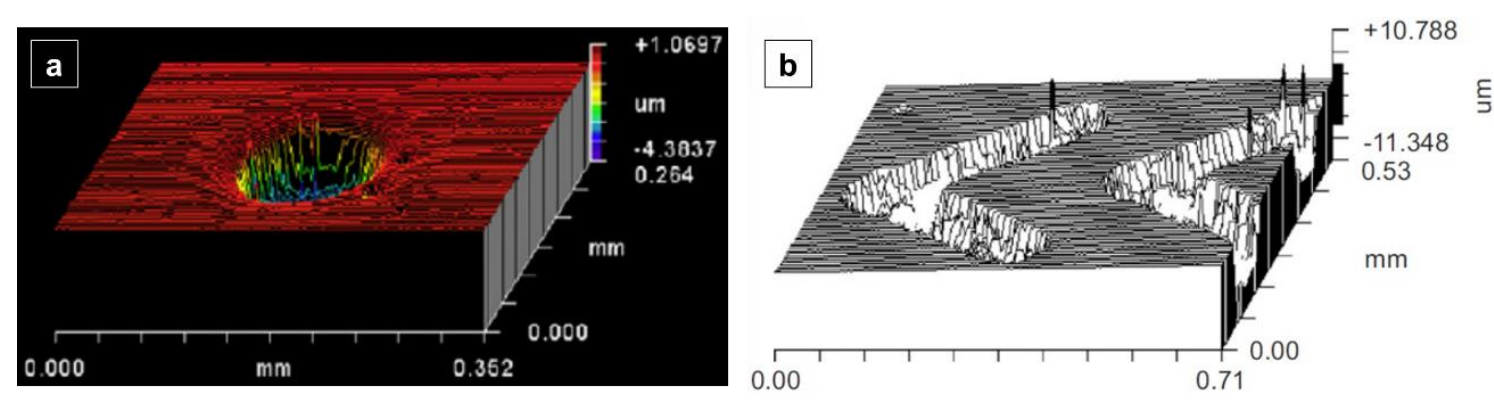

Fonte:(COSTA; HUTCHINGS, 2007, 2009), adaptada pelo autor.

Além dos aspectos dimensionais e geométricos, outros pontos influenciam na qualidade e desempenho tribológico das texturas. Etsion (2013), Vladescu et al. (2016) e Bhaduri et al. (2017) discutem os prejuízos que o aumento da rugosidade, aparecimento de arestas e rebarbas, decorrentes dos processos de estruturação de superfícies, causam nos produtos.

O departamento de pesquisa e desenvolvimento da empresa thyssenkrupp vislumbrou o potencial de aperfeiçoamento tribológico das superfícies funcionais e desenvolveu uma geometria especial de textura para ser empregada em virabrequins. A patente US 2015/0204377 A1 (SALLES; CARDOSO; DUARTE, 2015) traz os detalhes técnicos dessa estrutura. A ideia é produzir micro cavidades nos assentos de mancais de virabrequins segundo restrições de perfil e rugosidade. Tais cavidades têm o objetivo de reduzir o atrito e aumentar as forças de sustentação do virabrequim em operação. O perfil genérico da textura pode ser observado na Figura 2.3. A textura é um conjunto de duas rampas assimétricas, de inclinações diferentes, uma mais 
suave e outra mais acentuada. A rampa mais suave favorece a entrada de fluido na cavidade, enquanto a rampa mais acentuada gera uma turbulência na saída do óleo. Essa turbulência tende a gerar uma maior força de sustentação no virabrequim. Portanto, a fabricação dessa textura deve ser fiel à forma e dimensão projetada, do contrário, as melhorias tribológicas não ocorrerão. Além da geometria da textura, a patente cita ainda a necessidade de um número mínimo de texturas por peça, para que os efeitos sejam atingidos

Figura 2.3 - Perfil genérico da textura desenvolvida pela thyssenkrup.

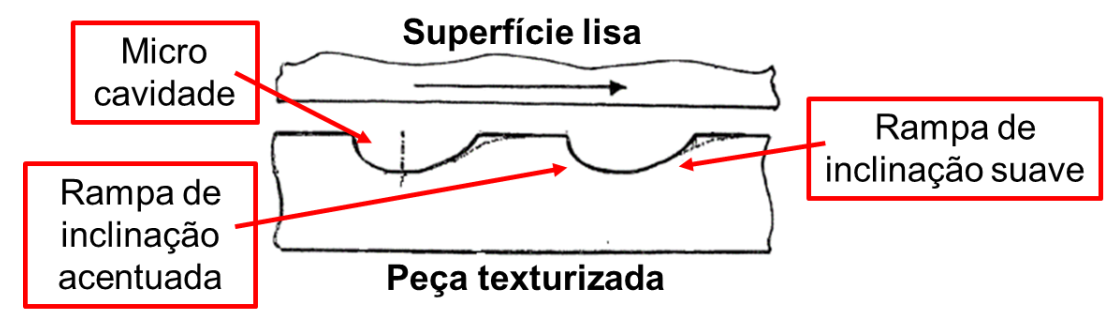

Fonte: Patente US 2015/0204377 A1 (SALLES; CARDOSO; DUARTE, 2015), adaptado pelo autor.

\subsection{Texturização por retificação}

Li e Axinte (2016) apresentam uma revisão completa sobre rebolos com padrões geométricos, mostrando trabalhos que estudam não só rebolos padronizados para inscrição de texturas, como rebolos estruturados para melhorar o processo de retificação convencional. Eles classificam a superfície dos rebolos com áreas ativas (interagem com a peça durante a retificação) e passivas. Estas podem melhorar o transporte de fluido refrigerante para a zona de retificação, mas não têm participação direta no processo de remoção de material. A revisão também traz outras classificações de texturas, um histórico de trabalhos nessa área e um estudo geométrico da cinemática durante o contato rebolo padronizado e peça.

O estudo da topologia do rebolo é um tema pesquisado há algum tempo. Como a retificação utiliza uma ferramenta de corte com arestas de geometria indefinida, o rebolo, o controle da sua superfície tem influência direta na qualidade superficial da peça retificada. O estudo de Oliveira (1988) mostra a importância da preparação do rebolo e as estratégias para afiação e condicionamento, a chamada operação de dressagem. A cinemática da interação entre rebolo e a ferramenta de dressagem 
(dressador) causa um macroefeito na superfície do rebolo. Diferentes formatos de dressador e condições de dressagem mudam o macroefeito gerado. Stepién e Szafarczyk (1989) analisaram esse fenômeno e propuseram uma metodologia para texturização de superfícies por retificação.

Nessa proposta de Stepién e Szafarczyk (1989) a geração de texturas no rebolo se dá por uma estratégia análoga à produção de roscas por torneamento, executando a dressagem com velocidades transversais (velocidade de avanço de dressagem $v_{d}$ ), superiores às típicas. As limitações dessa abordagem estão no tipo de contato entre rebolo e dressador e o posterior contato rebolo/peça durante a retificação, que restringe a geometria das texturas que podem ser obtidas (STEPIÉN; SZAFARCZYK, 1989). Na Figura 2.4 são mostradas as estruturas obtidas por Stpién e Szafarczyk (1989).

Figura 2.4 - Texturas obtidas com rebolo perfilado por Stépien e Szafarczyk em (1989).
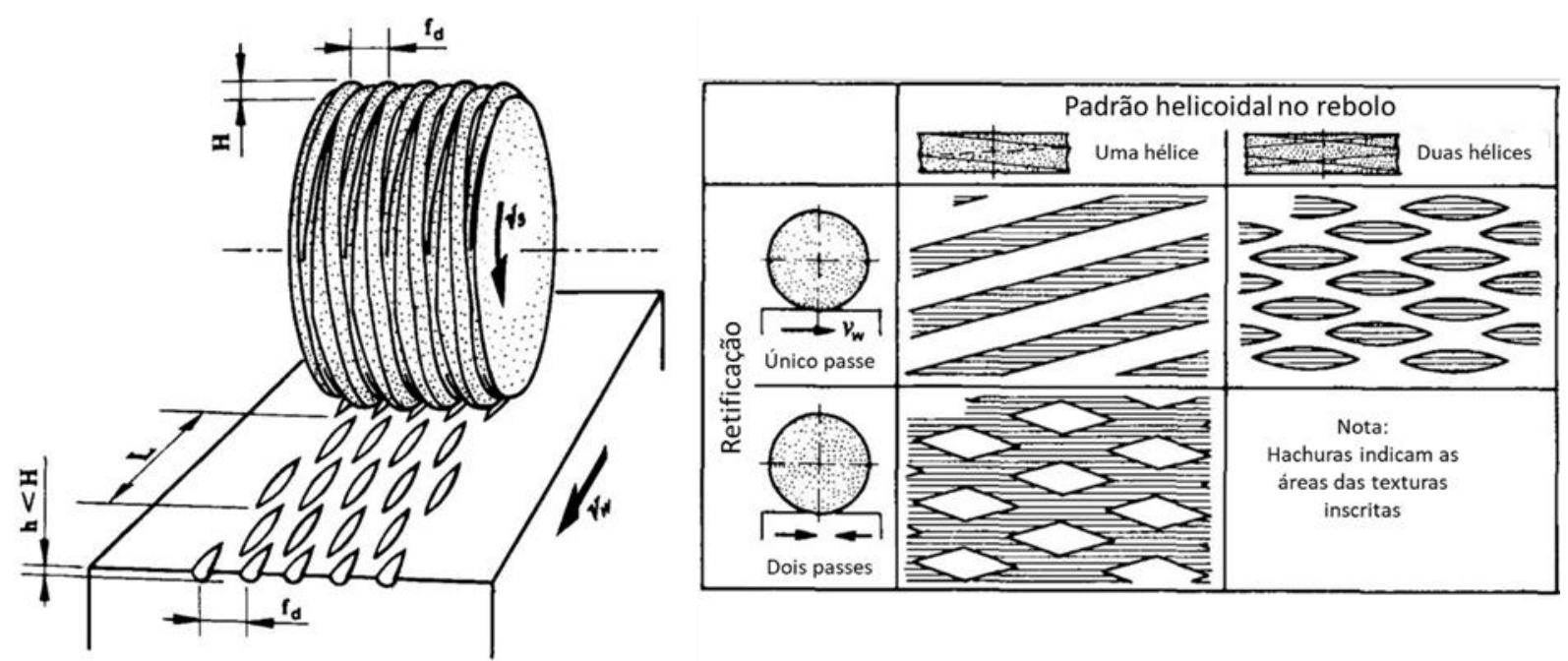

Fonte: (STEPIÉN; SZAFARCZYK, 1989), adaptada pelo autor.

Depois de Stepién e Szafarczyk, outros pesquisadores começaram a produzir peças texturizadas com rebolos padronizados. Alguns, ao invés de dressar o rebolo com o padrão geométrico desejado, produziram a ferramenta com uma geometria prédefinida referente à textura que desejavam fabricar. São ferramentas especiais fabricadas com ultra-precisão, onde se sabe exatamente a posição de cada grão, diferentemente de um rebolo convencional, no qual a distribuição dos grãos é aleatória. 
O experimento conduzido por Silva et al. (2017), utilizando um rebolo de CBN com ligante metálico especial e geometria pré-definida, introduziu texturas durante a retificação plana. Como a posição de cada grão é conhecida, controlando-se a cinemática do processo é possível descrever matematicamente a trajetória de cada grão. A combinação da forma do rebolo e deslocamentos da peça limita a geometria das texturas que podem ser produzidas. Além disso, a fabricação desses rebolos tem um custo elevado por conta da precisão de deposição dos grãos. A Figura 2.1 mostra a organização do experimento citado, expondo o rebolo padronizado, a unidade de deslocamento, capaz de movimentar a peça nas direções e y e velocidades necessárias, além de uma imagem da peça texturizada.

Figura 2.5 - Experimento de texturização com rebolo engenheirado.



Fonte: (SILVA et al., 2017), adaptado pelo autor.

Outra metodologia envolve a manipulação da operação de preparação do rebolo, promovendo uma dressagem dinâmica, com alteração da profundidade de dressagem durante o processo, o que altera o perfil superficial do rebolo. Nesse caso, o rebolo é convencional, sem arranjo especial dos grãos, com ligante que permite a dressagem, diferente do caso anterior, em que o rebolo possui grãos eletrodepositados e qualquer operação de dressagem não altera a geometria do perfil. 
A introdução de um padrão geométrico é feita por uma excitação eletromecânica no dispositivo dressador, que altera com precisão a profundidade de dressagem ad, conforme apresentado na Figura 2-6. O dispositivo dressador é uma melhoria técnica do sistema de dressagem convencional, com a adoção de um eixo adicional de alta velocidade perpendicular à superfície do rebolo. A excitação é controlada por um software que emite sinais pertinentes ao padrão geométrico desejado. Dessa forma, o dressador "inscreve" no rebolo um padrão negativo ao desejado. Durante a operação de retificação, mantendo-se uma relação de velocidades inteira entre a peça e o rebolo, os padrões são transferidos para a peça (OLIVEIRA; BOTTENE; FRANÇA, 2010).

O processo de texturização pode ser dividido em três etapas, conforme apresentado na Figura 2.6. Na primeira se dá a concepção da textura desejada na peça, via software, sendo levada em conta a geometria do rebolo (diâmetro D e largura $T)$, velocidade de rotação do rebolo $\left(v_{s}\right)$, o grau de recobrimento $\left(U_{d}\right)$ desejado e a geometria do dressador (largura de dressagem $b_{d}$ ). Na segunda etapa, os sinais gerados pelo programa são enviados ao dispositivo eletro-mecânico durante a dressagem, o que resulta no rebolo padronizado. Por último, a superfície do rebolo inscrita com padrões geométricos realiza a remoção do material da peça durante a retificação. A razão entre a velocidade angular do rebolo $\left(n_{s}\right)$ e da peça $\left(n_{w}\right)$ deve ser um número inteiro para manter o alinhamento das texturas durante o processo. Se isso não for obedecido, a cada volta da peça, as próprias texturas do rebolo removem as texturas criadas na volta anterior.

Outro recurso importantíssimo na aplicação desse método é a instrumentação da retificadora com sensores de emissão acústica (EA) e unidade de tratamento do sinal de EA. O sistema de monitoramento por EA capta as características da onda emitida pelo contato entre grãos abrasivos e dressador ou peça e a posição angular do rebolo para visualizar a superfície da ferramenta. Um software de mapeamento acústico combina a largura, comprimento e intensidade RMS da EA para reproduzir a superfície. Esse recurso, desenvolvido por Oliveira e Dornfeld (2001), permite controlar melhor os processos de retificação e dressagem, além de mostrar o perfil do rebolo com padrões geométricos. 
O desenvolvimento dessa metodologia começa com a primeira publicação em 2010 e o complemento em 2012 (OLIVEIRA; BOTTENE; FRANÇA, 2010; BOTTENE, 2012). Os pesquisadores apresentaram a técnica e obtiveram os primeiros resultados. Nesses trabalhos, o atuador do dressador é um equipamento bastante robusto, um shaker, tipicamente utilizado para aplicar vibrações em toda estrutura da máquina. Esse atuador foi a principal limitação das texturas produzidas nas peças, restringindo a forma obtida à variações de ondas senoidais e a profundidades máximas de $25 \mu \mathrm{m}$ (no rebolo ou na peça). A Figura 2.7 apresenta as texturas obtidas. Nota-se que diferentes padrões geométricos foram alcançados apenas com a alteração do sinal gerado para o atuador, sem mudança de ferramental.

Figura 2.6 - Esquema do sistema de texturização utilizado por Oliveira, Bottene e França (2010).

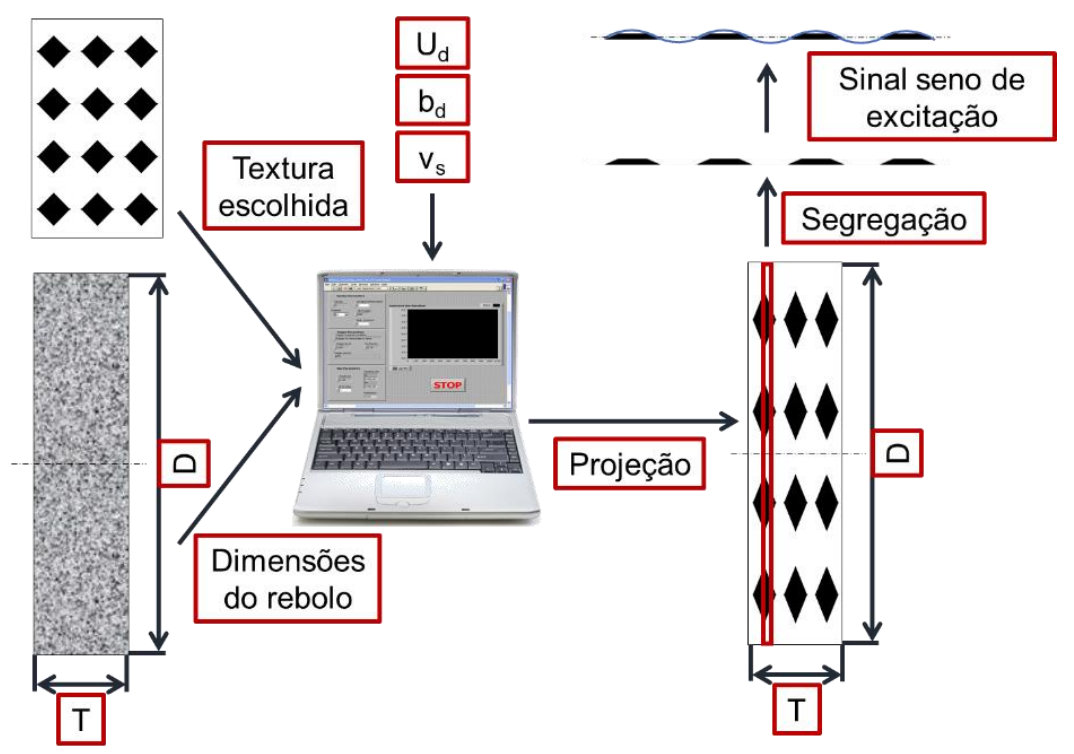

Fonte: (OLIVEIRA; BOTTENE; FRANÇA, 2010), adaptado pelo autor. 
Figura 2.7 - Peças texturizada por rebolos dinamicamente dressados.

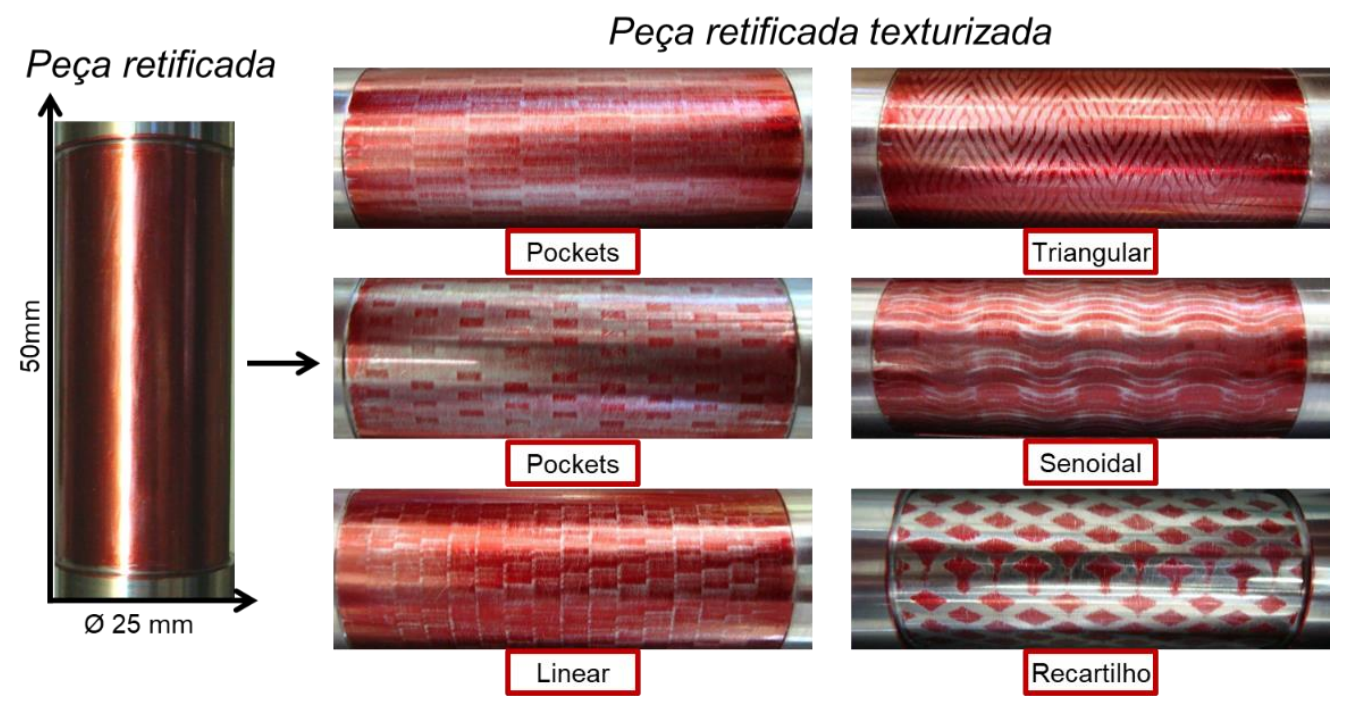

Fonte: (OLIVEIRA; BOTTENE; FRANÇA, 2010), adaptado pelo autor.

Em Silva et al. (2013) foi desenvolvido um procedimento para atender padrões de qualidade na texturização. Com maior controle sobre o macroefeito oriundo das texturas e o microefeito da dressagem, pode-se alterar a rugosidade nas partes externas e internas da textura. Esse interesse particular tem grande influência em peças texturizadas para aprimoramento de funções tribológicas, baixos valores de rugosidade no exterior da textura geram menor atrito, enquanto rugosidades elevadas no interior da textura tendem a reter mais óleo. A Figura 2.8 mostra o resultado desse desenvolvimento com a expectativa da geometria final de peças submetidas a duas estratégias diferentes. No primeiro caso (Figura 2.8a), o rebolo é padronizado pela dressagem dinâmica e passa por uma segunda dressagem, estática, removendo os picos dos padrões no rebolo. Posteriormente, a peça é texturizada. Na segunda abordagem (Figura 2.8b), o rebolo recebe os padrões geométricos pela dressagem dinâmica, texturiza a peça e uma nova retificação, com um rebolo sem padronização, remove as cristas da textura na peça. Este trabalho também apresenta uma nova unidade dressadora, com um novo atuador piezoelétrico inserido em uma estrutura mecânica com efeito elástico que melhora a movimentação do dressador. O esquema de funcionamento desse novo sistema de dressagem é apresentado na Figura 2.9. 
Figura 2.8 - Estratégias para controle de rugosidade de peças texturizadas.

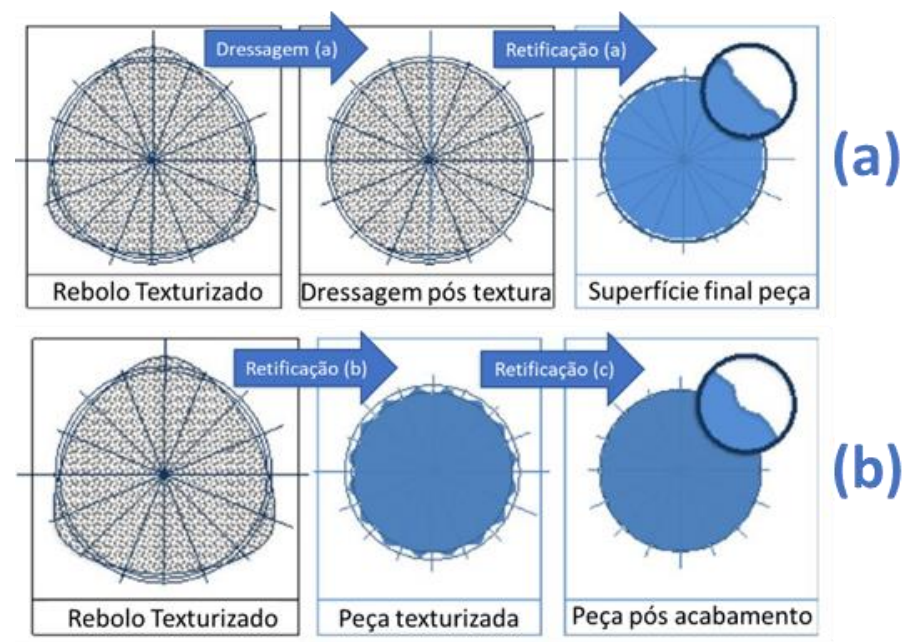

Fonte: (SILVA et al., 2013), adaptado pelo autor.

Figura 2.9 - Sistema de texturização de rebolos com atuador piezoelétrico.



Fonte: Próprio autor.

Silva et al. (2016;) mostrou em uma nova contribuição a última evolução desse método. Mais uma vez a unidade dressadora foi remodelada, uma nova estrutura de proteção para o atuador operar no ambiente da retificação foi projetada. Essa estrutura herdou o conceito de um componente que gera um efeito elástico para dar mais controle e estabilidade ao sistema. Foram apresentados novos resultados de texturização, agora com um processo muito mais bem controlado e capaz de produzir geometrias mais complexas. A cinemática do contato entre rebolo padronizado e peça 
foi modelado matematicamente, tornando previsível a trajetória dos grãos do rebolo padronizado. Essa modelagem mostrou que a cinemática da retificação acaba por arredondar texturas mais pontiagudas durante a inscrição das texturas na peça. Uma análise dinâmica da unidade dressadora apresentou os limites do atuador quanto à máxima amplitude de deslocamento em função da frequência de excitação. Por fim, um simulador de contato foi desenvolvido, capaz de prever a forma da textura na peça. A construção do simulador leva em conta a geometria e a cinemática do contato entre dressador e rebolo; entre rebolo padronizado e peça; e as velocidades de resposta do atuador. A Figura 2.10 é um comparativo da circularidade medida de uma peça texturizada e a circularidade obtida no simulador desenvolvido. Observa-se que as circularidades são bem semelhantes, o que mostra a confiabilidade do simulador.

Figura 2.10 - Comparativo de medida de circularidade e circularidade simulada.

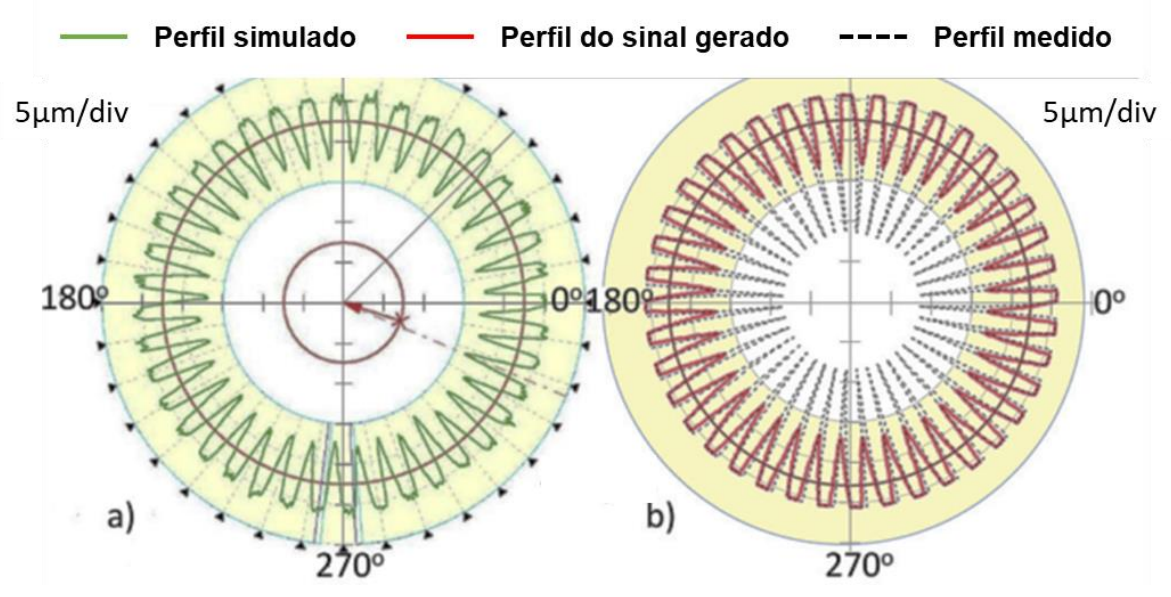

Fonte: (SILVA et al., 2016), adaptado pelo autor. 


\section{REQUERIMENTOS DE PROJETO PARA O DESENVOLVIMENTO DE UM SISTEMA DE TEXTURIZAÇÃO PARA REBOLOS DE CBN COM LIGANTE VITRIFICADO}

Os casos de sucesso apresentados por Oliveira et al. (2013), Silva et al. (2013) e Silva et al. (2016) foram desenvolvidos para a texturização de rebolos convencionais de óxido de alumínio. Este tipo de rebolo pode ser dressado com ferramentas de ponta única, o que torna simples seu acoplamento a um sistema de deslocamento linear. Os trabalhos de Oliveira et al. (2010) e Silva et al. (2013) mostram como o sistema funciona além das estratégias envolvidas para a texturização de uma peça. Além do dressador de ponta única, outro ponto que simplifica a dressagem dinâmica de rebolos convencionais são as baixas velocidades de trabalho. Tipicamente, esses rebolos operam em velocidades periféricas $\left(v_{r}\right)$ de $30 \mathrm{~m} / \mathrm{s}$. A influência da velocidade no processo se dá pelo fato de, na padronização do rebolo, o dressador precisar inscrever um segmento do padrão geométrico por volta do rebolo, ou seja, quanto maior a velocidade de rotação do rebolo, maior deve ser a frequência de oscilação do dressador.

Rebolos de CBN requerem a utilização de discos rotativos para que a operação de dressagem seja produtiva. Dressadores de ponta única se desgastam muito rapidamente, já que os grãos de CBN têm dureza quase 2,5 vezes maior que os de óxido de alumínio. Maior dureza aliada ao maior ponto de fusão dos grãos abrasivos faz com que as velocidades de trabalho dos rebolos de CBN atinjam $120 \mathrm{~m} / \mathrm{s}$, sem comprometer a integridade da peça retificada (MALKIN; GUO, 2008). A complexidade de movimentar um dressador rotativo e as altas frequências de oscilação necessárias pela maior velocidade de rotação dos superabrasivos representam os grandes desafios desse projeto.

Além de viabilizar a inserção de padrões geométricos em rebolos de CBN, o trabalho visa à produção de uma geometria específica. Uma textura otimizada para mancais hidrodinâmicos, desenvolvida e patenteada pela empresa thyssenkrupp, que diminui o atrito e aumenta as forças de sustentação do mancal em operação. Os detalhes técnicos estão disponíveis na patente depositada US 2015/0204377 A1 (SALLES; CARDOSO; DUARTE, 2015). Outras características dessa textura serão expostas ao longo do capítulo em partes oportunas. 


\subsection{Particularidades do processo de dressagem com discos rotativos para rebolos de CBN de ligante vitrificado}

Para a dressagem de rebolos de CBN, dressadores estacionários, de ponta única ou de múltiplas pontas não são indicados devido ao rápido desgaste. Apesar de o diamante ter maior dureza que o CBN, vários grãos de CBN se chocam contra o dressador, causando maior desgaste aos diamantes.

Tipicamente, ferramentas rotativas são utilizadas para a dressagem de rebolos de CBN. Dependendo da aplicação, a geometria dessas ferramentas varia, podendo ser discos dressadores, discos perfiladores, rolos de forma ou em forma de copo. A característica desses dressadores é a presença de camadas de diamante em sua periferia. Isso faz com que haja um contato de múltiplos grãos de diamante com o rebolo, aumentando a vida útil do dressador.

Dressadores que possuem a mesma largura do rebolo (ou maior), só precisam de movimentação radial (mergulho) para dressar. Já as ferramentas que não tem esse engajamento total, como os discos, requerem avanço lateral, ou seja, a operação de dressagem é análoga à das ferramentas estacionárias. Portanto, a velocidade transversal de dressagem $\left(v_{t}\right)$ influencia na característica da superfície do rebolo. Velocidades maiores aumentam a rugosidade do rebolo e diminuem as forças de retificação, uma vez que a agressividade do rebolo é maior nesses casos (KLOCKE, 2009).

Tais ferramentas são acionadas por um motor para que toda sua periferia interaja com o rebolo. Existem também rolos acoplados a sistemas de frenagem. Nesse caso, quando em contato, o rebolo rotaciona o dressador e o freio diminui a velocidade de rotação do rolo para uma fração da rotação do rebolo (MALKIN; GUO, 2008).

Devido à interação entre dressador e rebolo, outros fatores, que não ocorrem em dressadores estáticos, influenciam na topografia resultante. Um dos fatores de maior influência é a relação de velocidades ou razão de esmagamento $\left(q_{d}\right)$, definida pelo quociente da velocidade periférica do dressador $\left(v_{d}\right)$ pela velocidade periférica do rebolo $\left(v_{s}\right)$ (ROWE, 2014). 
A relação de velocidades é positiva (+) se o movimento ente rebolo e dressador for concordante ou negativa (-) se o movimento for discordante. Um $q_{d}$ positivo tende a criar uma superfície mais fina e plana no rebolo (JACKSON; DAVIM, 2011). Diferentes valores de $q_{d}$ geram diferentes regimes de fratura de grãos. Em geral, valores baixos produzem mais micro-fraturas, gerando elevada densidade de arestas de corte e, consequentemente, maior vida útil do rebolo. Porém, as forças de retificação também aumentam. Quando $q_{d}$ atinge valores maiores, obtém-se, predominantemente, macro-fraturas, que têm efeito contrário, expondo menos arestas de corte, diminuindo a vida do rebolo, mas também diminuindo as forças de retificação (MALKIN; GUO, 2008). Esses efeitos estão diretamente ligados à rugosidade efetiva do rebolo e podem ser observados na Figura 3.1.

Figura 3.1 - Efeito da razão de esmagamento na rugosidade do rebolo.

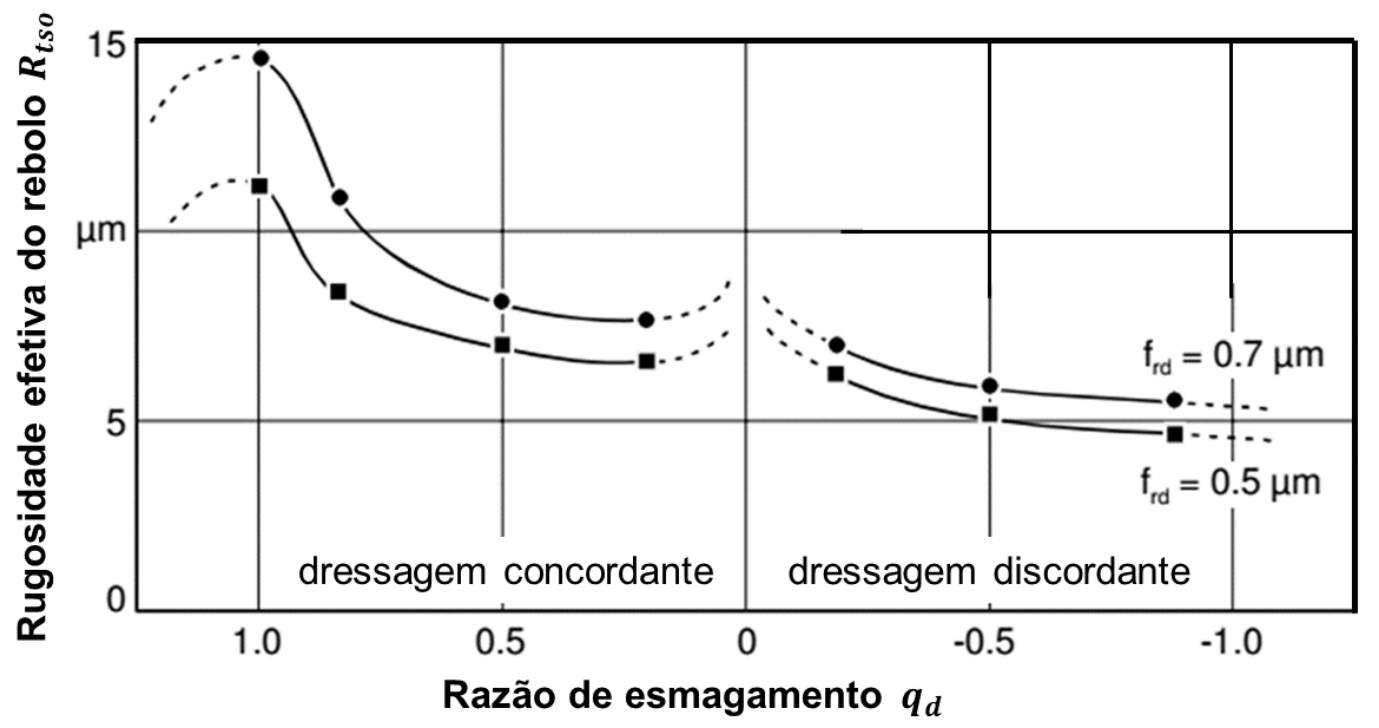

Fonte: (KLOCKE, 2009), adaptada pelo autor.

Para menores forças de dressagem e menor rugosidade da peça retificada, a relação de velocidades deve ser baixa $q_{d}<1$. Em todos os casos, o dressador deve estar rigidamente montado na unidade acionadora para evitar desvios e vibrações que afetarão a precisão da dressagem e a topografia do rebolo (ROWE, 2014).

A profundidade de dressagem $a_{d}$ também tem influência sobre a rugosidade final do rebolo. No caso do CBN, pequenas profundidades, da ordem de $5 \mu \mathrm{m}$ são indicadas. Além de diminuir o consumo excessivo do rebolo, pequenos $a_{d}$ diminuem 
o desgaste do dressador e as tensões que atuam sobre ele durante a dressagem. No entanto, baixos valores de $a_{d}$ levam a uma superfície menos agressiva do rebolo, pois expõem menos arestas de corte. Por isso, logo após a dressagem, as primeiras operações de retificação geram maiores forças. Esse efeito não dura muito, já que com o decorrer dos ciclos de retificação o ligante é consumido e as forças diminuem (MALKIN; GUO, 2008).

É recomendável dressar o rebolo em sua velocidade de trabalho para evitar erros de balanceamento, já que, normalmente o rebolo deve ter seu melhor balanceamento em sua velocidade de retificação.

\subsection{Conceito do dispositivo a ser desenvolvido}

Além das particularidades da dressagem de rebolos de CBN vitrificado, outras restrições são impostas para o projeto do sistema de texturização.

A geometria da textura de interesse, a microrampa desenvolvida na patente US 2015/0204377 A1 (SALLES; CARDOSO; DUARTE, 2015), requer frequências e amplitudes de movimento específicas. Se o sistema não for capaz de responder à essas exigências, a textura fabricada não gerará o efeito tribológico desejado. Como o dressador utilizado tem forma de disco, a interação entre dressador e rebolo é diferente da que ocorre quando um dressador de ponta única é empregado. $O$ contato deixa de ser um ponto e passa a ser um arco de circunferência, ou seja, passa a ter um comprimento definido, restringindo a geometria das texturas geradas.

A técnica de texturização durante a dressagem envolve a alteração dinâmica da profundidade de dressagem pela movimentação da ferramenta dressadora. Com um dressador de ponta única, isso é relativamente fácil, pois o mesmo pode ser acoplado à extremidade de um atuador. Já a dressagem de rebolos de CBN vitrificado requer um outro ferramental, com um disco dressador acoplado a um motor. Esse conjunto é muito mais difícil de ser movimentado nas frequências desejadas devido à sua elevada massa. 


\subsubsection{Restrições impostas pela geometria a ser produzida}

O processo de produção de peças texturizadas por retificação consiste em duas etapas: dressagem para inscrição dos padrões geométricos na superfície do rebolo e retificação para transferir a textura à peça.

Independentemente da composição do rebolo, a premissa básica para a texturização dos rebolos é a capacidade de o sistema variar dinamicamente a profundidade de dressagem de acordo com a posição angular instantânea do rebolo. Dois elementos são essenciais para o conjunto: o dressador e um sistema capaz de oferecer deslocamento radial preciso em altas frequências de excitação. O dressador modela o rebolo pela variação da profundidade de corte com auxílio de um atuador de movimentação radial. A qualidade da dressagem está diretamente relacionada à qualidade das texturas finais na peça. Portanto, o conjunto dressador-atuador deve ser suficientemente rígido para não prejudicar a operação de dressagem.

É importante ressaltar que as texturas típicas para aplicação em mancais são geometricamente pequenas, com dimensões de profundidade da ordem de dezenas de micrometros, Borghi produziu e testou em um tribômetro texturas de $50 \mu \mathrm{m}$ de profundidade (BORGHI et al., 2008), e Abdel-Aal, em sua revisão sobre projeto de texturas, traz exemplos de casos de sucesso para aplicações tribológicas com texturas de profundidades de $15 \mu \mathrm{m}$ até $30 \mu \mathrm{m}$ (ABDEL-AAL, 2016). A Figura 3.2 mostra as dimensões de uma textura típica em forma de dimple estudada por Galda et al. (2009), onde se pode perceber uma profundidade de $60 \mu \mathrm{m}$. Portanto, a amplitude dos deslocamentos necessários para que a unidade dressadora padronize o rebolo são bem pequenas (da mesma ordem de dezena de micrometros).

Figura 3.2 - Dimensões típicas de uma textura em forma de dimple.

a

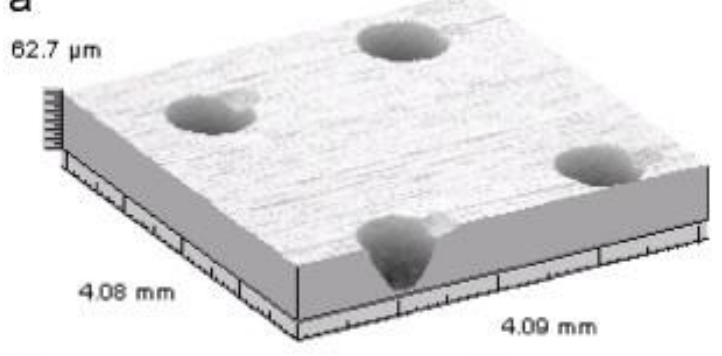

b

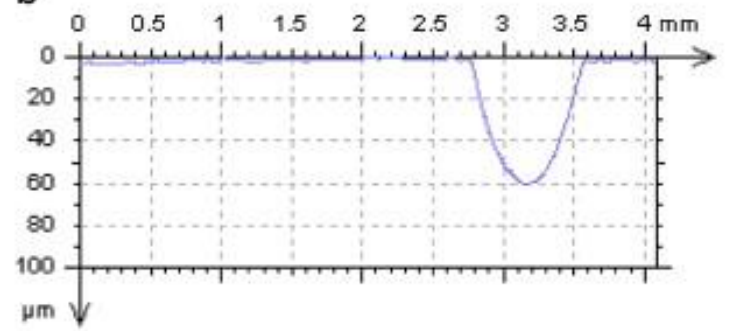

Fonte: (GALDA; PAWLUS; SEP, 2009), adaptado pelo autor. 
A geometria da textura desejada, a microrampa desenvolvida na patente US 2015/0204377 A1, pode ser simplificada para uma composição de duas rampas com inclinações opostas, como mostrado na Figura 3.3. As inclinações determinam a entrada e saída de fluido lubrificante da textura. A proporção dessas inclinações é fator determinante para alcançar o efeito tribológico requerido. A geometria de interesse tem razão ideal próxima de $1(x)$ para $5(y)$, ou seja, um comprimento de esmagamento do fluido 5 vezes maior que o da região de admissão. Adicionalmente, a profundidade $(h)$ deve ter entre $6 \mu \mathrm{m}$ e $12 \mu \mathrm{m}$ e a textura deve estar homogeneamente distribuída pela superfície da peça. A forma desejada é genérica, com tolerâncias de forma razoavelmente flexíveis, podendo ser aproximada por uma combinação de duas ondas seno, como representado na Figura 3.4.

Figura 3.3 - Textura de interesse (microrampa).

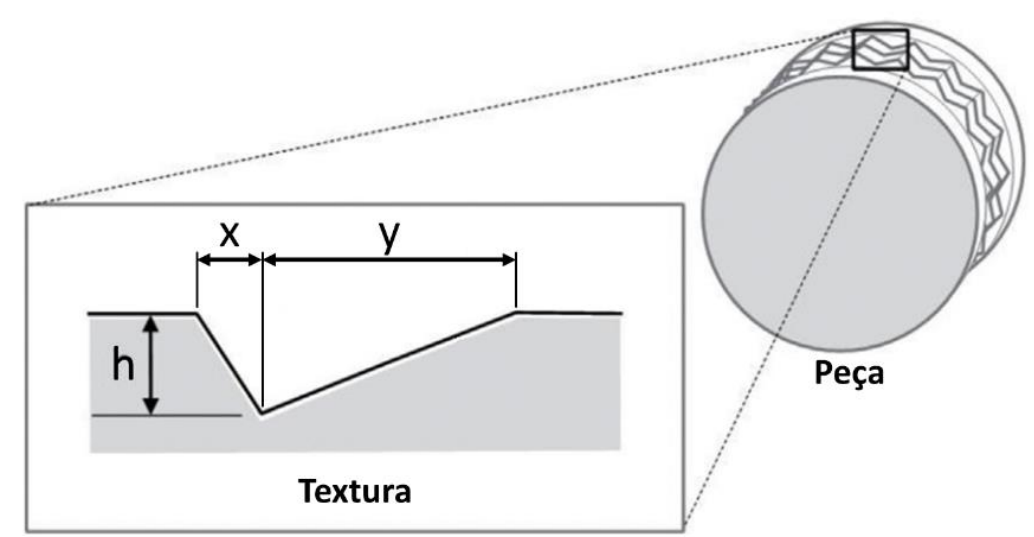

Fonte: (SILVA et al., 2016) adaptado pelo autor.

Figura 3.4 - Características de perfil da microrampa.

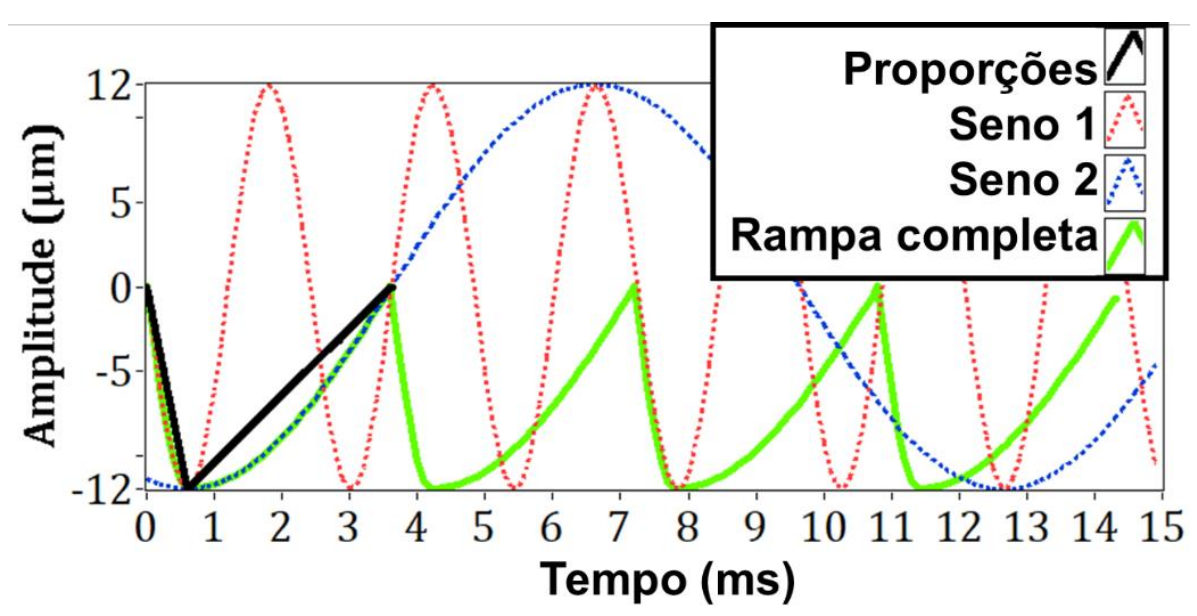

Fonte: Próprio autor. 
Diferentemente de outras estruturas bastante estudadas como dimples e chevrons, que são geometrias mais constantes, as rampas desejadas possuem inflexão, ou seja, mudança abrupta de direção. Isso traz maiores desafios para a dinâmica do processo, exigindo maior resposta e precisão de posicionamento do sistema. No caso dos dimples, por exemplo, o movimento é muito mais natural para o atuador, sendo aproximado por uma única onda senoidal de mesma frequência.

Para obtenção da forma da rampa, o atuador deve responder em duas velocidades diferentes, de avanço e de retração. Essas velocidades podem ser previstas avaliando-se o deslocamento das duas inclinações (Figura 3.4) e o tempo que os deslocamentos devem ser efetuados. O tempo é função do movimento do disco ao longo do perímetro do rebolo. Portanto, o menor segmento da textura, o de maior inclinação, é o que requer maior velocidade. Considerando um rebolo de $400 \mathrm{~mm}$ de diâmetro, velocidade periférica $v_{s}=80 \mathrm{~m} / \mathrm{s}$, apenas um padrão na periferia do rebolo e um atraso de $8 \%$ referente ao tempo de comunicação e atuação do sistema, o segmento de entrada é representado por um quarto de uma curva seno de frequência $414 \mathrm{~Hz}$. Analogamente, um quarto de outra curva seno de $83 \mathrm{~Hz}$ representa o segmento de saída. Com a velocidade periférica do rebolo e seu perímetro tem-se o tempo de uma volta do rebolo. Descontando-se os $8 \%$ de atrasos tem-se o tempo que o atuador pode agir por volta $(0,01445$ segundos). Como só uma microrampa será gerada nesse perímetro, o tempo é divido em seis partes, uma mais rápida e cinco mais lentas (proporção 1:5 da textura). Invertendo o resultado dessa divisão descobrese a frequência do segmento mais rápido.

\subsubsection{Restrições geométricas da interação rebolo e disco dressador}

Para inscrição de padrões geométricos na superfície de rebolos convencionais, a ferramenta de dressagem é composta por um único grão de diamante, portanto sua interação com o rebolo é a trajetória de um ponto sobre uma superfície. Assim, a geometria do dressador ponta única é mais propícia para a geração de uma textura em forma de rampa. Já na dressagem de rebolo superabrasivo de CBN com ligante vitrificado utilizando-se um disco diamantado, a geometria da interação dressador e rebolo muda. A trajetória de contato descrita pelo dressador não é mais a de um ponto, mas de um arco de circunferência, resultante da intersecção entre o diâmetro do disco 
e o diâmetro do rebolo na profundidade de dressagem adotada. Esse fator faz com que o menor segmento que o disco consiga impor sobre a superfície rebolo seja esse arco de contato. $O$ comprimento deste arco é função da profundidade de dressagem, do diâmetro do disco, da protrusão dos grãos de diamante do dressador, das velocidades periféricas do rebolo e do disco, além do tipo de dressagem, concordante ou discordante.

O trabalho de CHOWDHURY et al. (2013) descreve a interação entre rebolo e disco dressador, mostrando as condições geométricas do contato e expondo as relações matemáticas para o cálculo do comprimento do contato. Na Figura 3.5 podese observar o esquema da interação rebolo e disco para dressagens concordantes e discordantes. Um rebolo de diâmetro $D_{g}$ gira a uma velocidade periférica $V_{g}$ e um disco dressador de diâmetro $D_{d}$ gira a uma velocidade periférica $V_{d}$. A direção de corte é concordante quando o sentido de rotação do rebolo é o mesmo que o do disco dressador, e o corte discordante ocorre quando os sentidos de rotação são opostos. Em ambos os casos, a profundidade de corte é dada por $t$. Um determinado número de partículas de diamante de comprimento $m$ está embutido na superfície do disco dressador e um grão de diamante é mostrado na figura como um exemplo. A extremidade dianteira do grão de diamante entra primeiro em contato com o rebolo no ponto $s$ e termina seu contato no ponto $e$. Com isso, determina-se o comprimento da trajetória do grão de diamante no disco dressador $l_{d} \mathrm{e}$, mais importante para o caso desse trabalho, a trajetória do grão de diamante na periferia do rebolo $l_{g}$.

Figura 3.5 - Condições geométricas de contato entre disco dressador e rebolo.

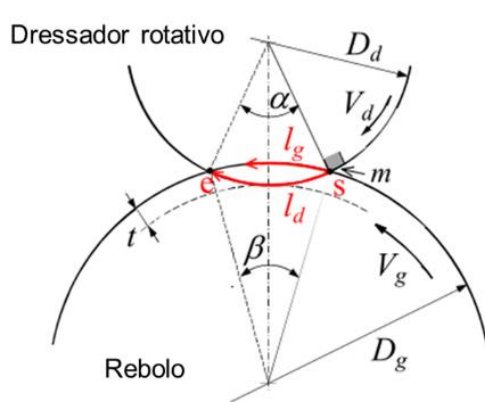

(a) Concordante

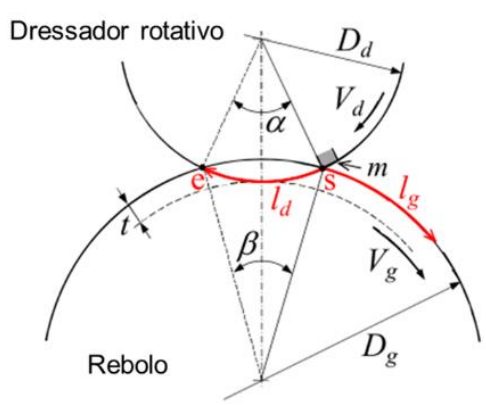

(b) Discordante

Fonte: (CHOWDHURY et al., 2013), adaptado pelo autor.

\footnotetext{
$D_{d}=$ diâmetro do disco

$D_{g}=$ diâmetro do rebolo

$V_{d}=$ velocidade do disco

$V_{g}=$ velocidade do rebolo $t=$ profundidade de dressagem $m=$ grão abrasivo do dressador $l_{d}=$ trajetória do grão no disco $l_{g}=$ trajetória do grão no rebolo $s=$ inicio do contato de $m$ com o disco $e=$ fim do contato de $m$ com o disco
} 


\subsubsection{Restrições construtivas do dispositivo}

Ao contrário dos dressadores de ponta única, que são leves e podem ser diretamente acoplados à extremidade de um atuador de deslocamento controlado, o sistema de dressagem rotativa engloba um disco diamantado acoplado a um motor elétrico, além de mancais que sustentam e dão rigidez. Ou seja, não é possível movimentar somente o disco dressador, ignorando os outros componentes do sistema. O sistema de dressagem completo possui uma grande massa. A excitação necessária para texturização é altamente influenciada pela inércia desse conjunto e sua falta de resposta em altas frequências.

\subsection{Projeto baseado em análise modal para maximização do desempenho funcional do sistema a ser desenvolvido}

Dadas as restrições supracitadas, propõe-se operar o sistema em sua frequência natural e, dessa forma, maximizar a resposta do conjunto dressador. Se a frequência de excitação do sistema for igual à sua frequência natural, as velocidades e amplitudes de movimentação radial do disco dressador serão maiores e poderão suprimir as dificuldades oriundas das restrições construtivas.

Assim, um dos desafios para atingir a geometria de textura desejada é projetar uma unidade que tenha uma frequência natural igual, ou próxima, da frequência de excitação máxima necessária para produção das texturas em questão, $414 \mathrm{~Hz}$. 


\section{MATERIAIS E MÉTODOS}

\subsection{Equipamentos e materiais}

Os ensaios de dressagem para inscrição de padrões geométricos na superfície do rebolo e texturização por retificação foram realizados no LAPRAS-NUMA-EESCUSP, em uma retificadora cilíndrica externa CNC Zema Numerika G-800-HS. A máquina dispõe de um sistema de monitoramento por emissão acústica Sensis MSM, utilizado para referenciamento, monitoramento do processo e aquisição do mapeamento acústico da superfície do rebolo (Oliveira e Dornfeld, 2001). Há também um sistema de balanceamento dinâmico do rebolo, Marposs E79, para compensar o desbalanceamento do rebolo durante a dressagem e retificação. A figura Figura 4.1 mostra a retificadora, enquanto a Figura 4.2, mostra o painel de controle da máquina e os sistemas de monitoramento.

Figura 4.1 - Retificadora CNC Zema Numerika G-800-HS.

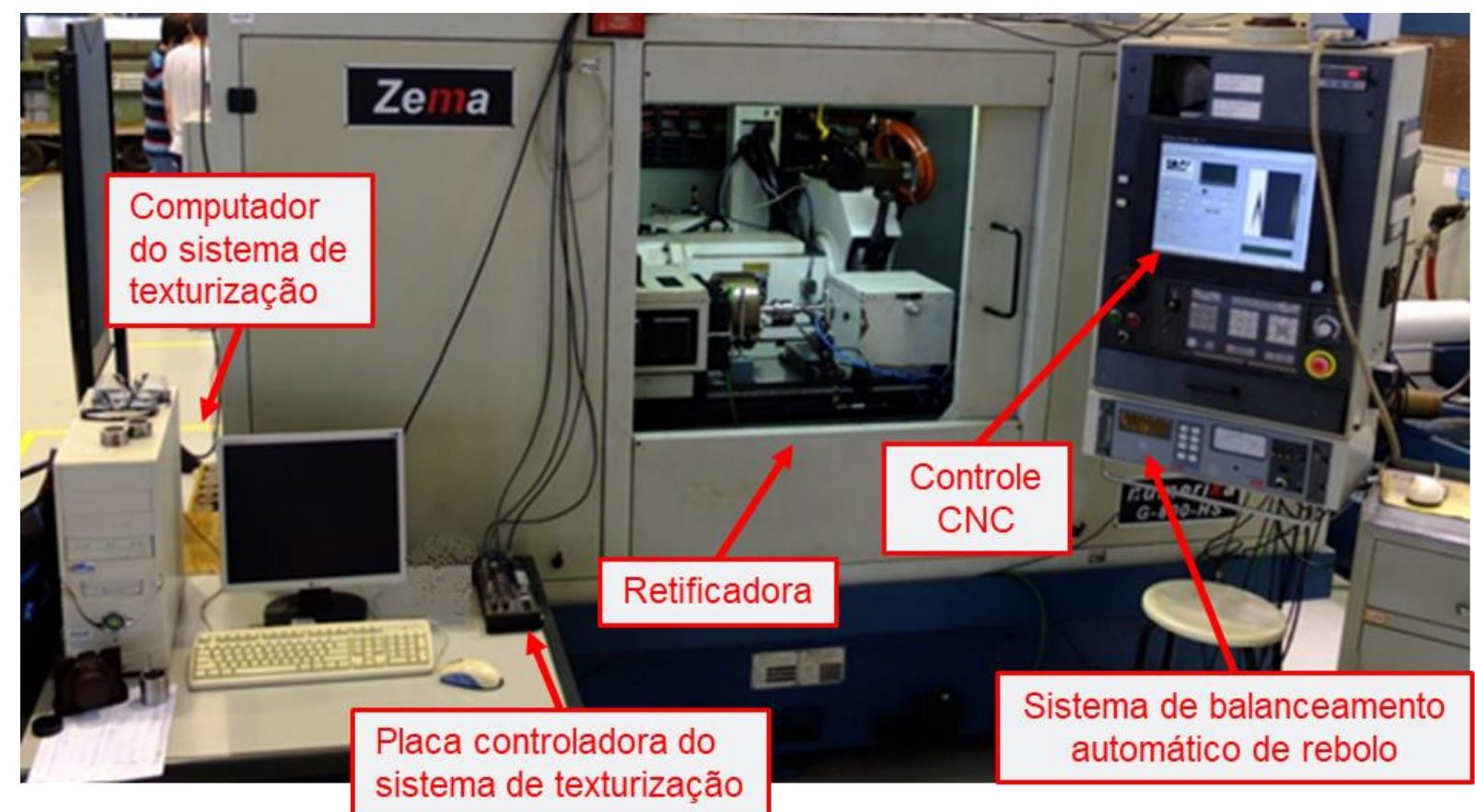

Fonte: Próprio autor. 
Figura 4.2 - Painel de operação e instrumentos da retificadora.

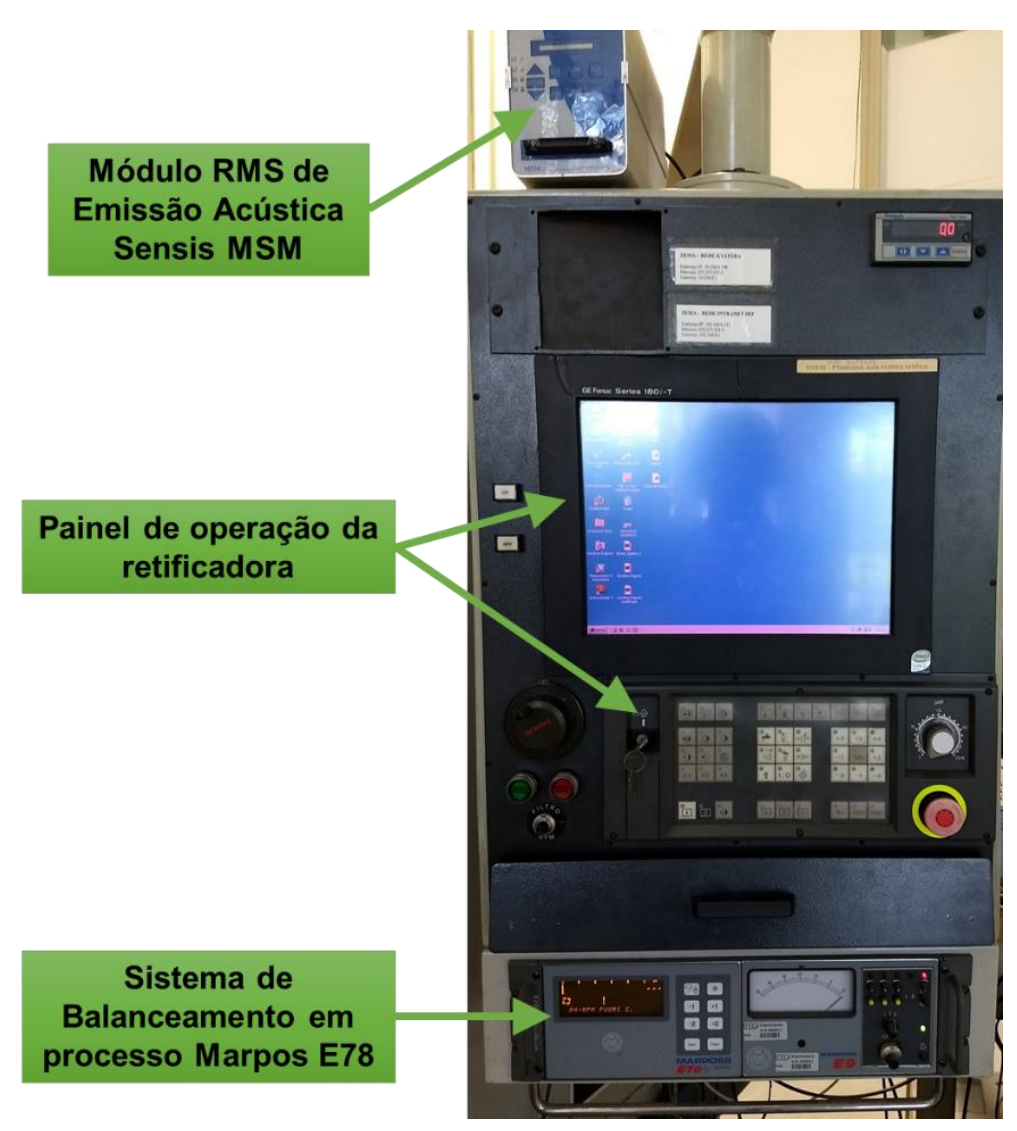

Fonte: Próprio autor.

Todas as dressagens, convencional (para perfilamento e condicionamento da superfície do rebolo) ou para inscrever padrões geométricos no rebolo, foram feitas com o sistema desenvolvido no trabalho, descrito no capítulo 3. O disco diamantado montado no sistema tem diâmetro externo de $127 \mathrm{~mm}$. No caso da dressagem convencional, a profundidade de dressagem era mantida constante ao longo do passe de dressagem (deslocamento axial do dressador na direção da largura do rebolo).

O rebolo utilizado foi de grão de CBN, tamanho do grão FEPA 126 (125 -106 $\mu \mathrm{m}$ ) com corpo metálico, ligante vitrificado e concentração 150 (especificação 8B126 K150 VT2). Ele possui 400 mm de diâmetro externo e 20 mm de largura.

Para os testes de texturização por retificação, foi fabricado um eixo de aço carbono AISI 1045 com três trechos retificáveis, de $50 \mathrm{~mm}$ de diâmetro e $22 \mathrm{~mm}$ de largura (Figura 4.3.). Dessa maneira, três condições diferentes poderiam ser testadas e posteriormente analisadas. 
Figura 4.3 - Desenho esquemático da peça utilizada para os testes de retificação

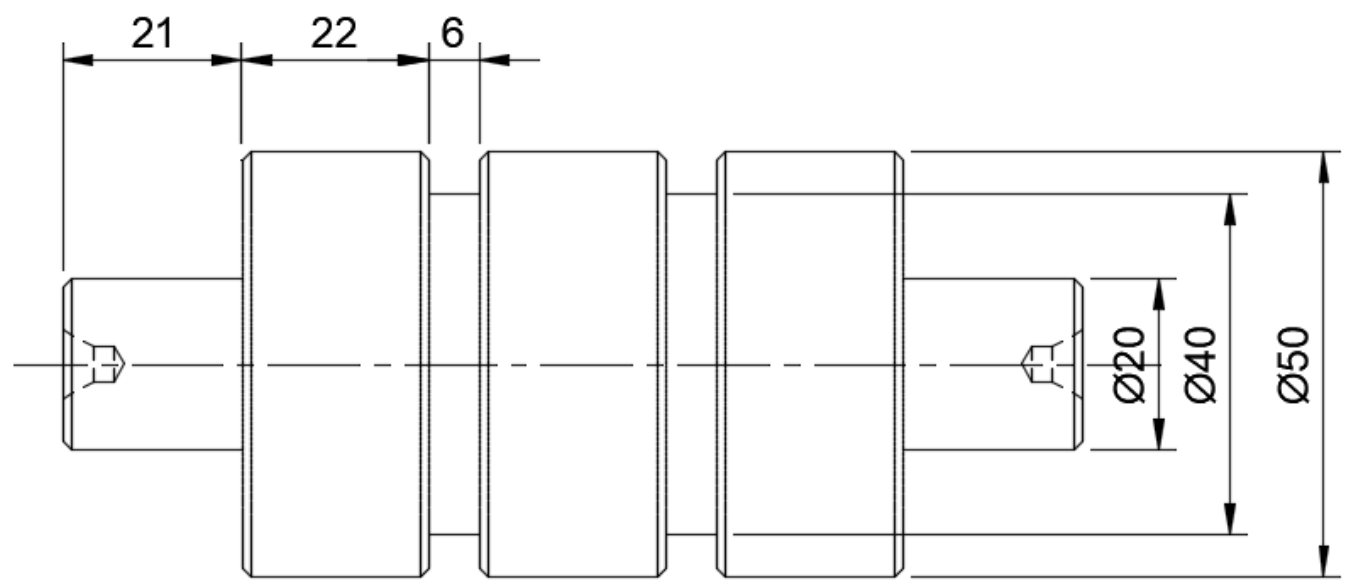

Fonte: Próprio autor.

As medições de circularidade das peças texturizadas foram realizadas no medidor de circularidade Talyround -131 e analisadas com o software $\mu$ tra, ambos da fabricante Taylor Robson. O equipamento fornece os valores de deslocamento da ponta de medição em contato com a peça em função de sua posição angular, com isso, obtém-se o perfil de uma seção circular da peça. Esse perfil mostra as inclinações e profundidades das texturas. Todas as medições foram feitas com uma ponta esférica de $2 \mathrm{~mm}$ de diâmetro, faixa de medição de $0,4 \mathrm{~mm}$ e o filtro utilizado nas análises foi de gauss 1-150upr. O gráfico gerado pelo $\mu$ ltra é adotado como referência para atestar a qualidade da operação de texturização. Os pontos desses gráficos foram exportados para que o perfil da rampa fosse comparado aos perfis gerados e simulados.

Medições do perfil longitudinal obtido na peça texturizada foram realizadas com um perfilômetro de contato modelo Talysurf 50, também da fabricante Taylor Hobson.

\subsection{Projeto inicial do sistema de dressagem para inscrição de padrões geométricos na superfície do rebolo}

\subsubsection{Considerações iniciais}

Na texturização por retificação, as inscrições são produzidas em duas etapas principais: a dressagem e a retificação cilíndrica externa em mergulho. Durante a dressagem, o deslocamento longitudinal do dressador é combinado com o movimento 
transversal do atuador para inscrição dos padrões. Após a dressagem, a retificação cilíndrica de mergulho é executada com o rebolo com os padrões geométricos desejados, adotando-se uma razão inteira de velocidades entre rebolo e peça, permitindo assim a transcrição das texturas à peça, quando da remoção do sobremetal de retificação.

O deslocamento transversal do dressador em relação ao rebolo é um movimento convencional das retificadoras $\mathrm{CNC}$, mas, dressadores típicos não possuem a capacidade de se deslocar radialmente em altas frequências de excitação. Portanto, o sistema de dressagem deve ser modificado para que efetue os deslocamentos exigidos para a inscrição dos padrões geométricos na superfície dos rebolos.

Uma alternativa clara para realizar as movimentações radiais necessárias para a padronização é deslocar toda unidade dressadora, acoplando a mesma a uma mesa posicionadora (conjunto deslizante com atuador piezoelétrico, por exemplo) como exemplificado na Figura 4.4. No entanto, a massa do spindle é relativamente grande para ser excitada na frequência de interesse, com a resposta e precisão necessária, o que exigiria um atuador muito robusto.

Figura 4.4 - Conceito de unidade dressadora movida por mesa posicionadora.

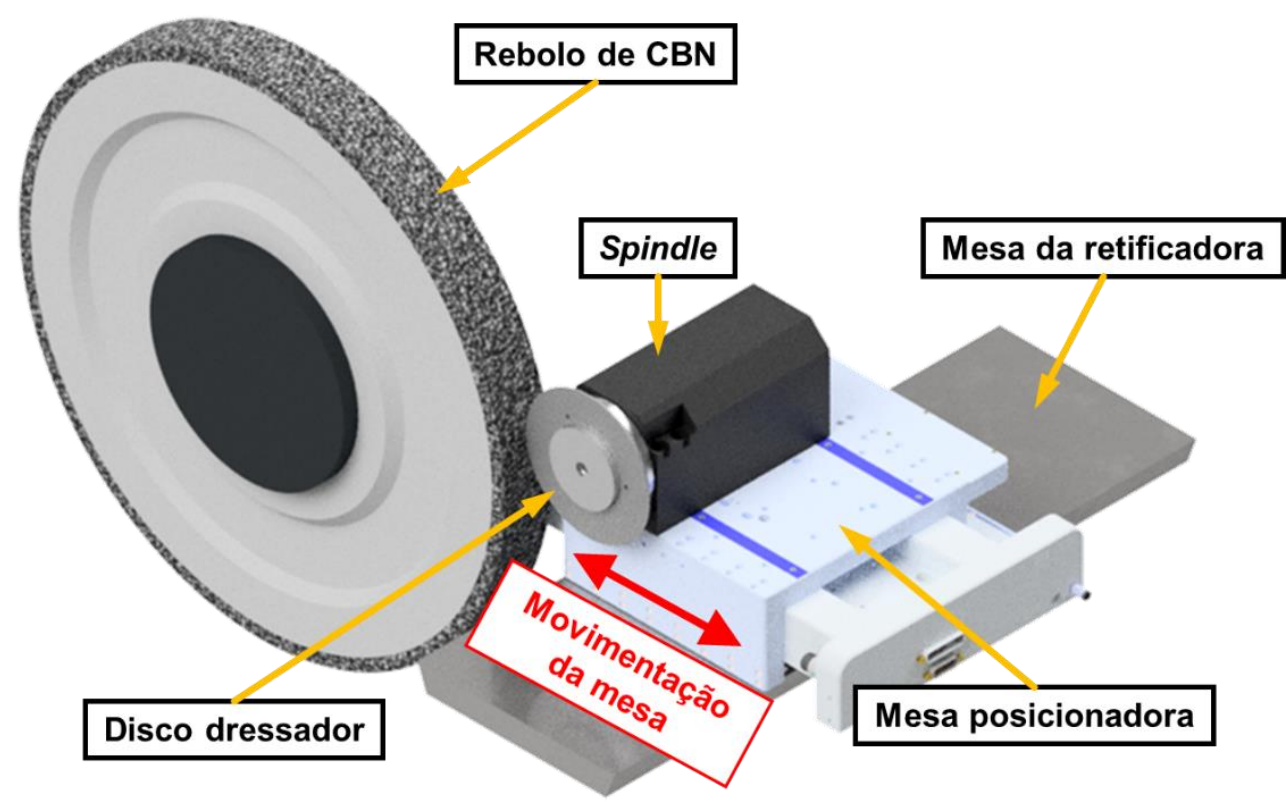

Fonte: Próprio autor. 
Para resolver o problema da grande quantidade de massa a ser movida, existe a possibilidade de se acoplar o atuador diretamente ao mancal do disco dressador. Entretanto, a estrutura que envolve esse mancal é projetada para ter alta rigidez. Assim, o conceito-padrão desse projeto mecânico precisa ser alterado. Os requisitos primordiais desse novo projeto são: resistência às forças radiais de dressagem e resposta às condições dinâmicas necessárias para a geração de perfis hidrodinâmicos.

O conceito a ser proposto deve ser capaz de movimentar o disco rotativo nas frequências de trabalho na direção radial. Tipicamente, o disco é montado na extremidade do eixo do motor, próximo ao mancal. Para manter essa concepção e alcançar a movimentação necessária para a texturização, deve-se reduzir a rigidez transversal do suporte do mancal e conectar o atuador piezoelétrico a esse suporte. A fragilização do suporte do mancal combinada com uma redução em uma seção do diâmetro do eixo garante a flexibilidade do sistema. Essas modificações são mostradas na Figura 4.5. Desse modo, a massa a ser movida é muito menor, composta apenas pelo disco, mancal e partes do eixo e do suporte do mancal. Como resultado, não se faz necessária a excitação de toda unidade de dressagem, mas apenas da região de acoplamento do disco. Como já destacado, os deslocamentos necessários para a texturização são pequenos, tornando a proposta de adicionar flexibilidade ao sistema e trabalhar na região de deformação elástica dos materiais empregados no projeto mais factível.

Figura 4.5 - Esquema da modificação da unidade dressadora.

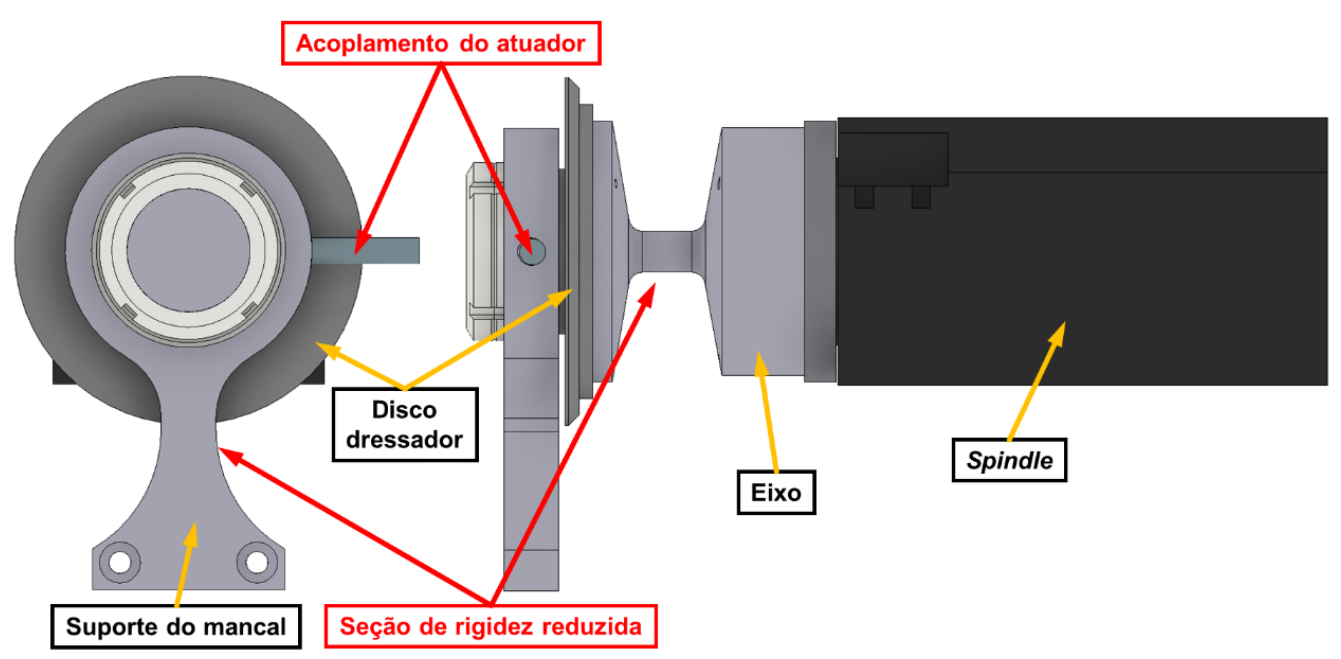

Fonte: Próprio autor. 
A nova unidade dressadora é composta por (Figura 4.6): spindle, eixo com uma seção do diâmetro reduzido (b), que conecta o motor ao disco e ao mancal montado em seu suporte que também conta com uma seção reduzida (a). Juntos, eixo e suporte do mancal conferem flexibilidade ao disco possibilitando um deslocamento controlado. Uma haste (c) transmite o movimento do atuador ao suporte. Todos esses componentes são montados sobre uma base que é fixada na mesa da retificadora CNC.

Figura 4.6 - Unidade dressadora proposta.

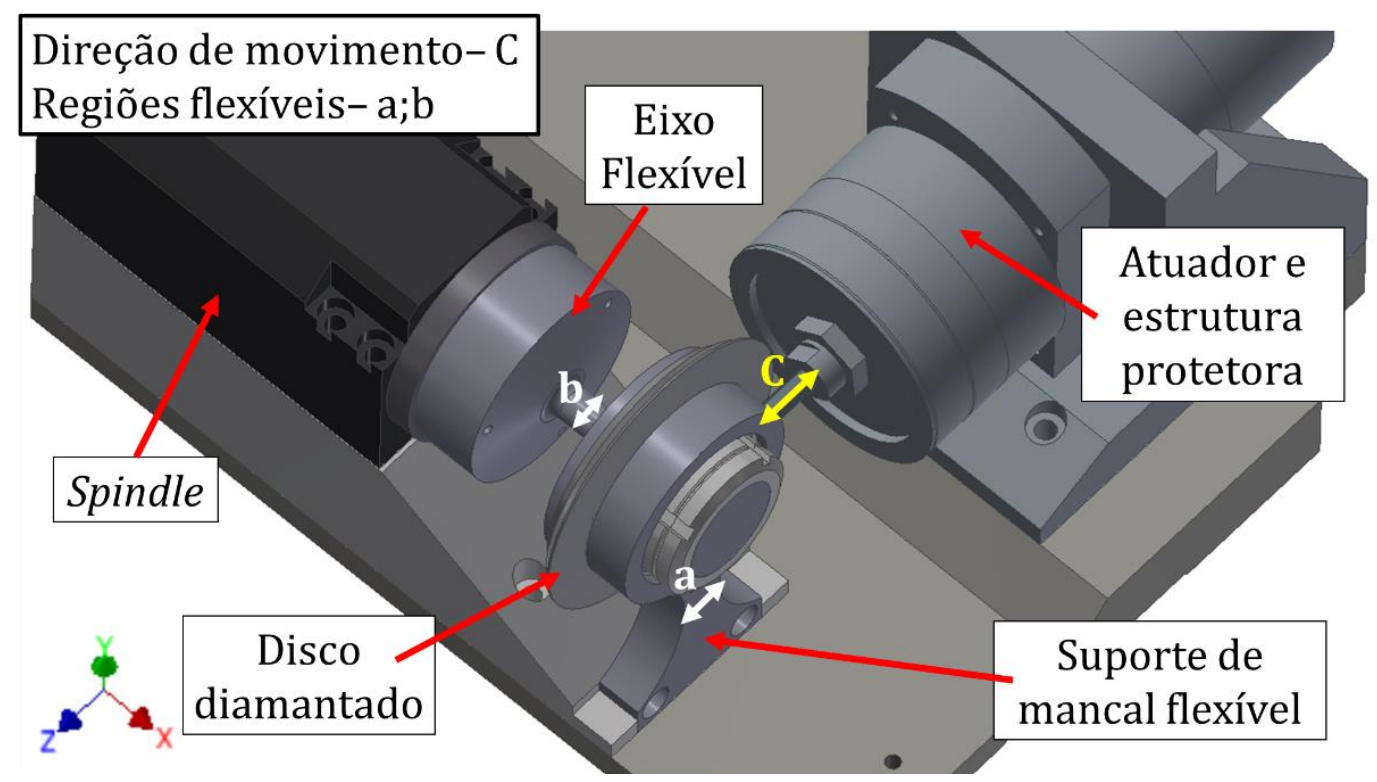

Fonte: (SILVA et al., 2018) adptado pelo autor.

Ao passo que a redução da rigidez de alguns componentes é necessária para possibilitar a movimentação do sistema, o mesmo deve ter resistência suficiente para aguentar os esforços de dressagem. Se o sistema for suscetível à vibrações não desejadas haverá comprometimento da dressagem e níveis de rugosidades superiores ao desejado serão obtidos na peça final. O suporte do mancal serve também como sustentação das forças tangencias oriundas do contato rebolo-disco dressador.

Mesmo com a redução da massa e a flexibilidade estrutural aplicada, esse sistema ainda é muito mais rígido que a unidade com dressador de ponta única. Além disso, excluindo a parte mecânica, a resposta em frequência do conjunto amplificador e atuador aponta para um sistema de primeira ordem com o amortecimento aparecendo em frequências superiores a $100 \mathrm{~Hz}$. A Figura 4.7 corresponde ao gráfico 
de resposta em frequência do amplificador utilizado, modelo E-481 da Physik Instrumente (PI). O atuador é também da PI, modelo P-225.8S, e tem capacitância de $2600 \mathrm{nF}$. Portanto sua curva no gráfico estaria entre a de $4000 \mathrm{nF}$ e $2000 \mathrm{nF}$.

Figura 4.7 - Curva de resposta do amplificador E-481.

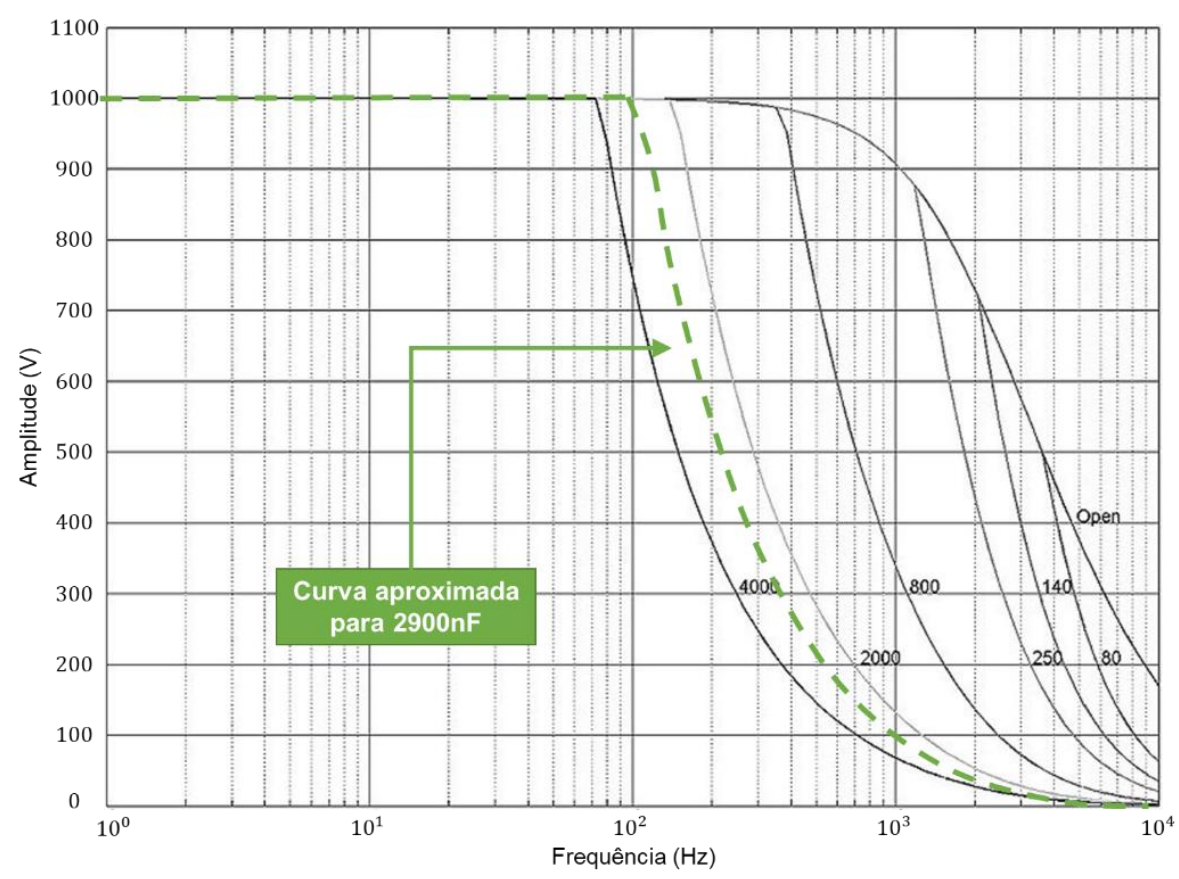

Fonte: (Physik Instrumente - E-481 User Manual, 2013), adaptado pelo autor.

A forma de se maximizar a resposta desse sistema é fazer com que ele opere em frequências próximas à natural. Assim, um dos desafios para atingir a geometria de textura desejada é selecionar as dimensões corretas das áreas com redução estrutural para se ajustar a frequência natural do conjunto de acordo com a frequência requerida para a aplicação.

A forma da textura na peça é diretamente afetada pelo segmento resultante do contato entre disco dressador e rebolo. $O$ disco dressador utilizado tem diâmetro externo de $127 \mathrm{~mm}$. Um disco de diâmetro menor geraria um arco de contato menor, aproximando mais para o tipo de interação dos dressadores ponta única, gerando um padrão geométrico no rebolo muito mais próximo do sinal de controle. No entanto, isso não seria suficiente para melhorar a textura da peça final, apenas o padrão geométrico inscrito no rebolo, neste caso, a rampa, uma vez que a transcrição da mesma para a peça tem influência da cinemática de contato do processo de retificação (Silva et al., 2016). O catálogo da fabricante de ferramentas de dressagem Winter, do grupo Saint- 
Gobain, possui discos diamantados com $60 \mathrm{~mm}$ de diâmetro externo, enquanto 0 catálogo da Dr. Kaiser traz discos com $40 \mathrm{~mm}$ de diâmetro. A utilização desse disco representaria uma redução da ordem de $40 \%$ do arco de contato. Todavia, optou-se por manter o disco de $127 \mathrm{~mm}$ de diâmetro externo, já que não era o escopo do projeto avaliar a influência da variação do diâmetro do disco dressador na qualidade dimensional dos padrões inscritos na superfície do rebolo.

Outra possibilidade de redução do arco de contato vem do trabalho de Chowdhury et al. (2013), que descreve como a relação de velocidades entre rebolo e dressador altera o comprimento de contato dinâmico. Os gráficos da Figura 4.8 mostram como o arco de contato varia de acordo com o tamanho do grão do dressador $(m)$; a profundidade de dressagem ( $t$ ); o tipo de dressagem, concordante ou discordante; e a relação de velocidades. Nota-se que quanto maior a relação de velocidades (extremos do eixo $x$ dos gráficos), menor o arco de contato. Em geral, a dressagem concordante tende a gerar arcos de contato menores. Contatos reduzidos também são obtidos com uma menor granulometria dos diamantes do disco dressador e com menores profundidades de dressagem.

Figura 4.8 - Variação do comprimento de contato entre disco e rebolo para diferentes relações de velocidade, granulometria e profundidade de dressagem.
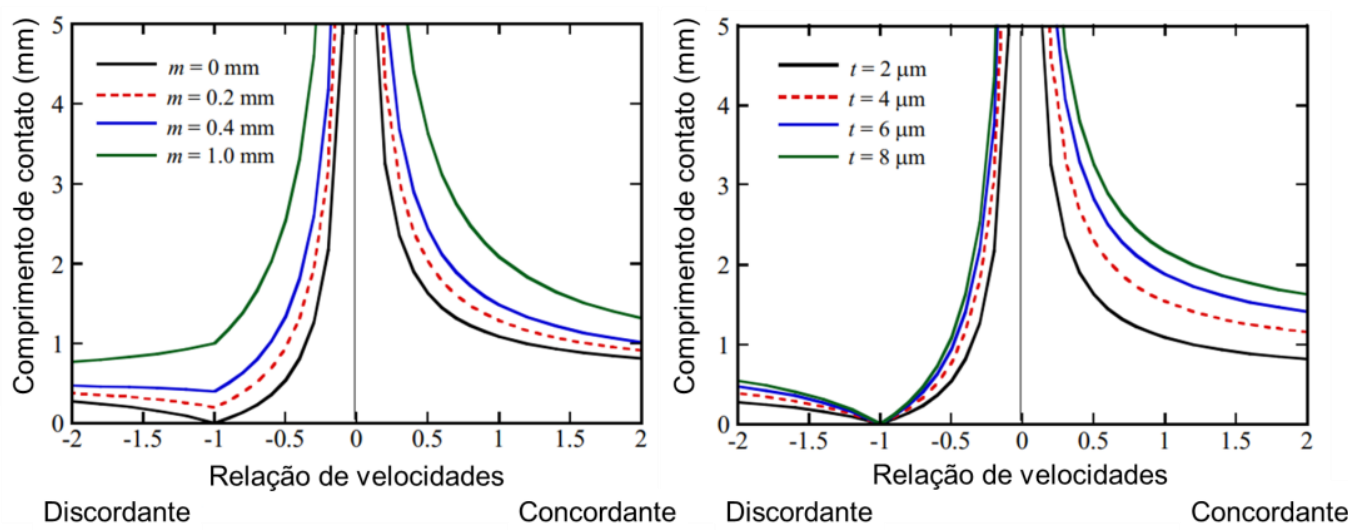

Fonte: (CHOWDHURY et al., 2013), adaptado pelo autor.

O motor de acionamento elétrico usado na unidade de dressagem projetada atinge uma rotação máxima da ordem de 4700 rpm. No catálogo de spindles para dressagem da Dr. Kaiser, há equipamentos com rotação de até 60000 rpm. Alterações na relação de velocidades modificam a razão de esmagamento da dressagem, o que influencia a rugosidade da peça. Todavia, a análise da variação dinâmica do arco de 
contato durante a dressagem por meio da modificação da razão de velocidades foi escopo deste trabalho.

Mais um ponto de reflexão está na frequência abordada. $O$ projeto foi feito buscando igualar a frequência natural do sistema à máxima frequência de excitação necessária para produção da rampa desejada. No entanto, a geometria da rampa tem um ponto de inflexão, que exige uma inversão no sentido de movimentação do atuador. Nesse ponto, a frequência de excitação do sistema é outra. Se a unidade dressadora tivesse sua frequência natural ajustada para o valor da inflexão, um perfil de rampa mais próximo ao ideal poderia ser gerado.

\subsection{Análise modal numérica}

A unidade dressadora proposta foi simulada numericamente para análise modal pelo método de elementos finitos, utilizando a versão educacional do software Autodesk Inventor 2018, para duas variáveis de projeto: a largura a do suporte do mancal; e o diâmetro $b$ do eixo (vide Figura 4.6). Os parâmetros de teste foram: $a=$ [10;15;20] $\mathrm{mm}$ e $b=[10 ; 12,5 ; 15] \mathrm{mm}$. No mundo real, a unidade dressadora será fixada à mesa da retificadora. Contudo, é difícil reproduzir a fixação real no ambiente de simulação. Portanto dois casos extremos de restrição foram aplicados à base da unidade dressadora: base totalmente fixa e base totalmente livre. A força foi posicionada na saída do atuador nos dois casos. O conjunto foi então analisado com uma malha otimizada, para a qual a tensão de von Mises variou menos de $10 \%$ entre duas iterações consecutivas, levando a 107758 elementos de malha tetraédricos. As figuras Figura 4.9 e Figura 4.10 mostram o modo de vibrar para a primeira frequência natural obtida na simulação para o caso da base fixa com $a=20 \mathrm{~mm}$ e $b=15 \mathrm{~mm}$, bem como os deslocamentos que o disco dressador sofre mediante a excitação imposta. 
Figura 4.9 - Primeiro modo de vibração do conjunto, no plano YZ, condição de base fixada.

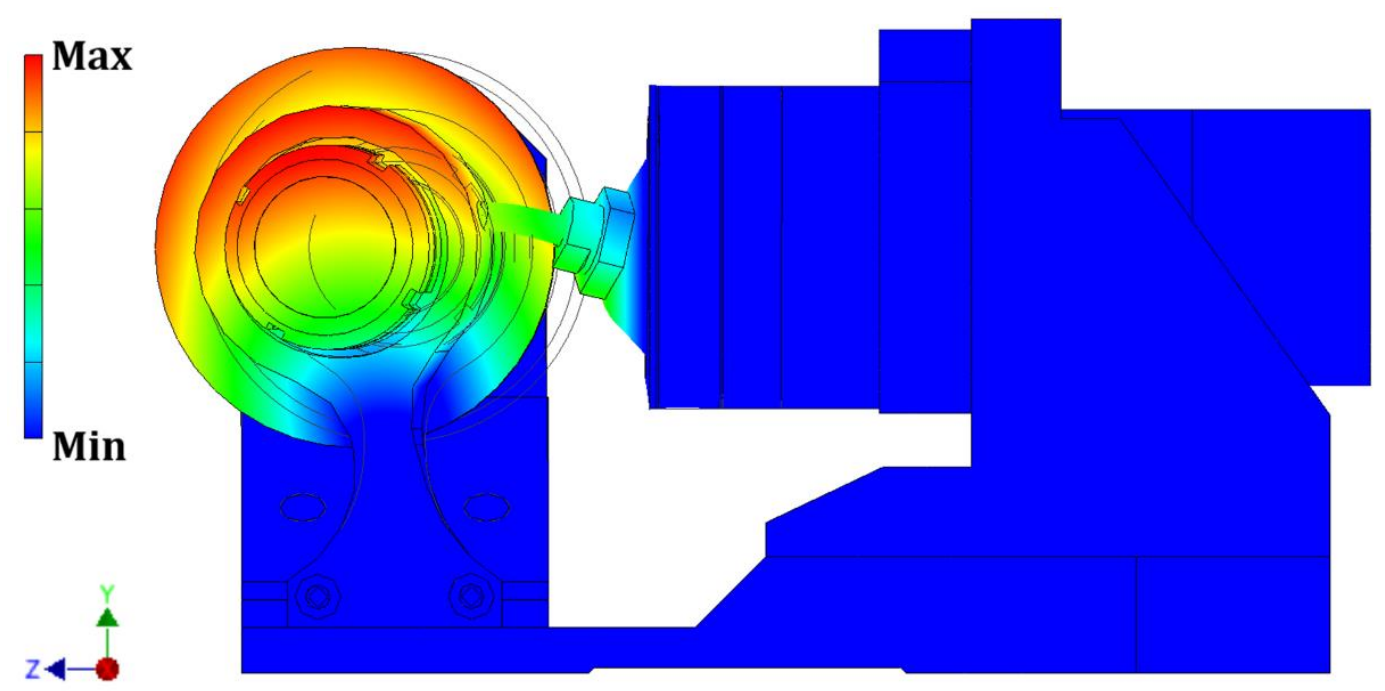

Fonte: Próprio autor.

Figura 4.10 - Primeiro modo de vibração do conjunto, no plano XZ, condição de base fixada.

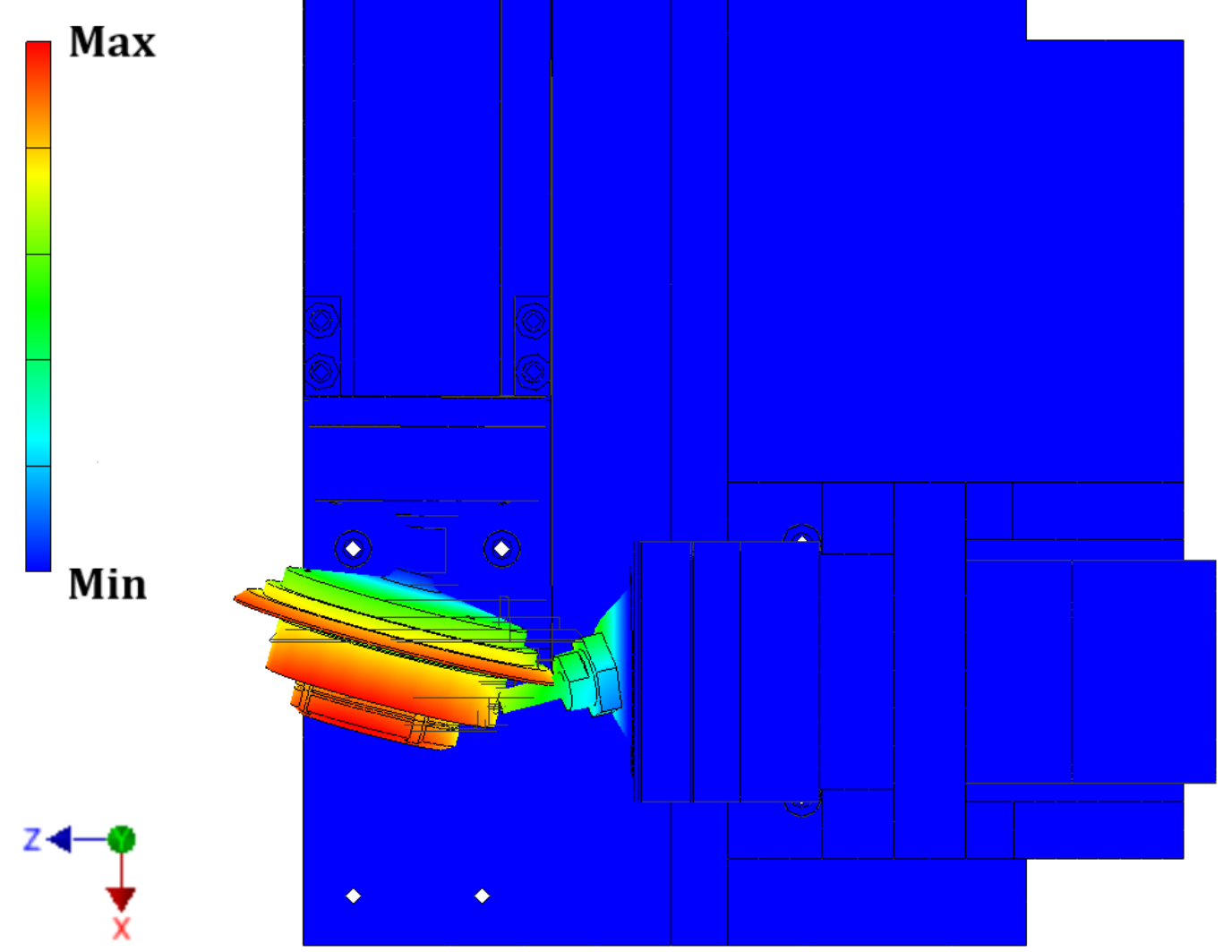

Fonte: Próprio autor. 
Das Figuras Figura 4.9 e Figura 4.10, pode-se observar que o modo de vibração obtido fornece o deslocamento para que o disco dressador consiga inserir o padrão geométrico desejado no rebolo. O disco dressador também sofre deslocamento na direção $x$, mas, devido à sua magnitude, esse efeito pode ser descartado. Mantendo a base fixa e variando o parâmetro a, como mencionado no parágrafo anterior, e mantendo $b=15 \mathrm{~mm}$, as seguintes frequências naturais ( $\omega n$ ) foram obtidas $\omega n=$ [495,1;544,77;609,1] Hz. Definindo $a=20 \mathrm{~mm}$ e variando $b$, as frequências resultantes foram $\omega n=[551,6 ; 580,4 ; 609,1] \mathrm{Hz}$. Portanto, a e $b$ estão relacionados à rigidez do sistema e podem ser tratados como parâmetros de projeto para ajustar a frequência natural da unidade dressadora.

Considerando-se o caso da base livre e fixando $a=20 \mathrm{~mm}$ e $b=15 \mathrm{~mm}$, a primeira frequência natural ocorre em $\omega n=236 \mathrm{~Hz}$. A real fixação do sistema na retificadora não é nem a condição de fixação perfeita, nem a condição totalmente livre. Assim, a primeira frequência natural para a condição real deve ser próxima à requerida (414 Hz), uma vez que as simulações trouxeram uma frequência natural média de 422,6 Hz (média das duas condições simuladas, entre 236 Hz e 609 Hz). Com esses resultados, as dimensões $a$ e $b$ foram definidas.

O atuador piezoelétrico responsável por oscilar o sistema possui uma força de expansão dos cristais (movimento de empurrar) de intensidade 12,5 kN. No entanto, não há informações que indiquem que essa força é constante para qualquer amplitude e frequência de trabalho. Além disso, o atuador está envolto por uma estrutura protetora, desenvolvida para que ele não seja danificado durante a operação. Tal estrutura pode interferir na força aplicada.

Com base nessas considerações e nas condições estruturais descritas anteriormente, foram feitas diversas simulações estáticas, aplicando-se uma força pontual no suporte do mancal, local onde o atuador é montado. A base da unidade foi definida como sendo o componente rígido e as outras peças montadas foram consideradas com restrição de movimento. A estrutura do atuador e a haste de ligação ao suporte do mancal foram desconsiderados. Em cada simulação foi alterada a intensidade da força, dentro dos limites nominais do atuador, a fim de se verificar a deformação dos componentes. Novamente, notou-se um deslocamento na direção $x$ que foi desconsiderado, sendo que apenas os deslocamentos em $z$ são relevantes. $O$ 
Quadro 4-1 expõe as condições simuladas e a deformação máxima na direção $z$ para a extremidade de interesse (ponta do disco, onde ocorrerá o contato com o rebolo). A Figura 4.11 mostra o resultado da simulação com força de $1250 \mathrm{~N}$, equivalente a $10 \%$ da força nominal do atuador, resultando num deslocamento de $28,83 \mu \mathrm{m}$.

Figura 4.11 - Resultado da simulação da estrutura submetida a uma força de 1250N.
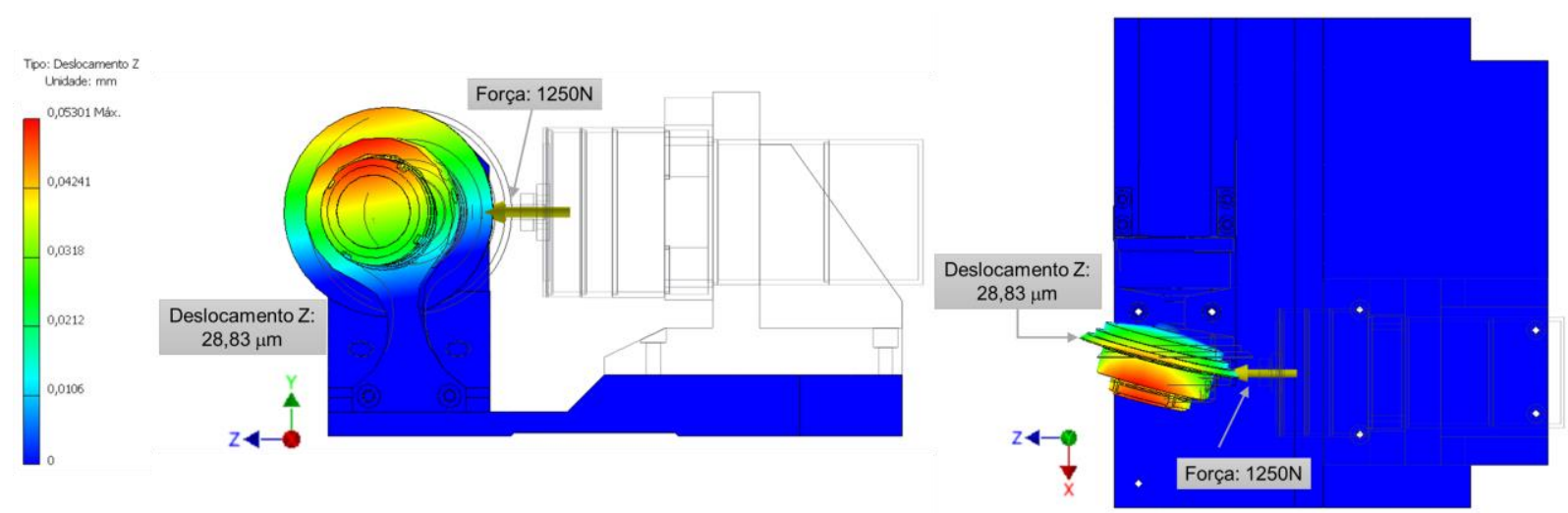

Fonte: Próprio autor.

Quadro 4-1 - Simulação de força de aplicação e deslocamento máximo do disco na direção Z.

\begin{tabular}{|c|c|c|c|c|c|}
\hline Força aplicada [N] & 12500 & 6250 & 1250 & 625 & 125 \\
\hline $\begin{array}{c}\text { Deslocamento } \\
\text { máximo do disco na } \\
\text { direção Z }[\mu \mathrm{m}]\end{array}$ & 289 & 144 & 29 & 14 & 3 \\
\hline
\end{tabular}

Fonte: Próprio autor.

O resultado da simulação foi satisfatório, já que o deslocamento necessário é entre $6 \mu \mathrm{m}$ e $12 \mu \mathrm{m}$. Portanto, se a real força aplicada pelo atuador for ao menos $625 \mathrm{~N}$, $5 \%$ da força nominal do atuador, a flexibilidade alcançada é a necessária para produção dos padrões geométricos hidrodinâmicos necessários em formato de rampa.

Com esses resultados, a unidade de dressagem proposta foi fabricada com os valores das dimensões das peças flexíveis $a=20 \mathrm{~mm}$ e $b=15 \mathrm{~mm}$. A Figura 4.12 é uma foto do interior da retificadora, mostrando o sistema fabricado e fixado. 
Figura 4.12 - Imagem do sistema montado na retificadora.

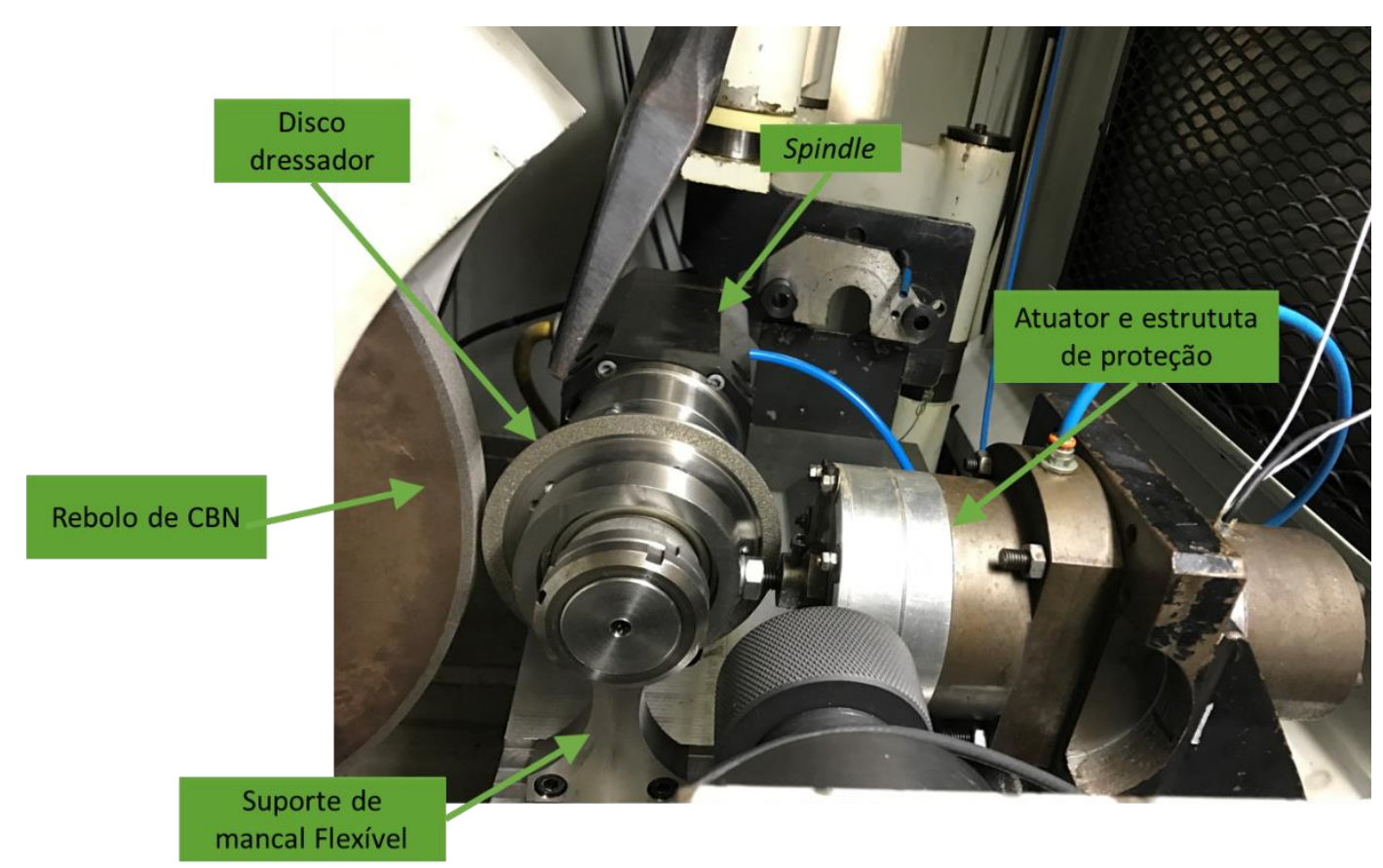

Fonte: Próprio autor.

\subsection{Análise modal experimental}

\subsubsection{Instrumentação do sistema de dressagem}

Para a análise modal experimental foram utilizados acelerômetros montados na unidade dressadora e no rebolo. Os acelerômetros utilizados são da marca PCB, modelos 352C33 e 353B03. Duas abordagens foram adotadas: coleta das respostas dos acelerômetros mediante a testes de impacto e a partir de sinais enviados ao atuador piezoelétrico. Para o teste de impacto, utilizou-se um martelo com transdutor de força PCB modelo 086C03.

Seguindo a nomenclatura do sistema de coordenadas dos eixos da própria retificadora, um acelerômetro foi posicionado no suporte do disco dressador na direção $X$ (eixo de movimentação radial da máquina) e no rebolo nas direções $x$ e $z$. A Figura 4.13 ilustra a montagem do acelerômetro e a direção do teste de impacto, enquanto a Figura 4.14 mostra a montagem dos acelerômetros e a direção de impacto no rebolo de CBN. 
Figura 4.13 - Imagem do sistema instrumentado para ensaios de resposta em frequência.

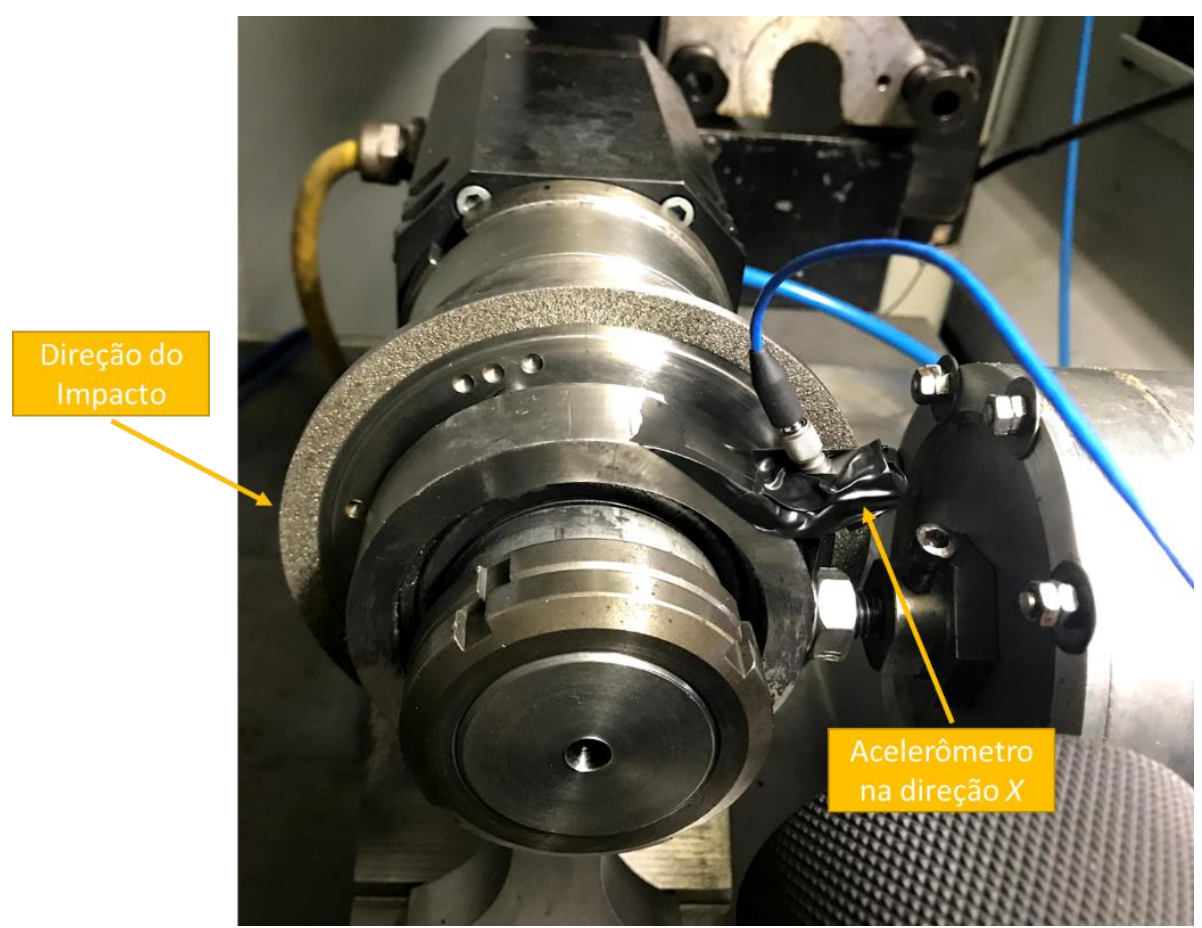

Fonte: Próprio autor.

Figura 4.14 - Montagem da instrumentação para o teste de impacto no rebolo.

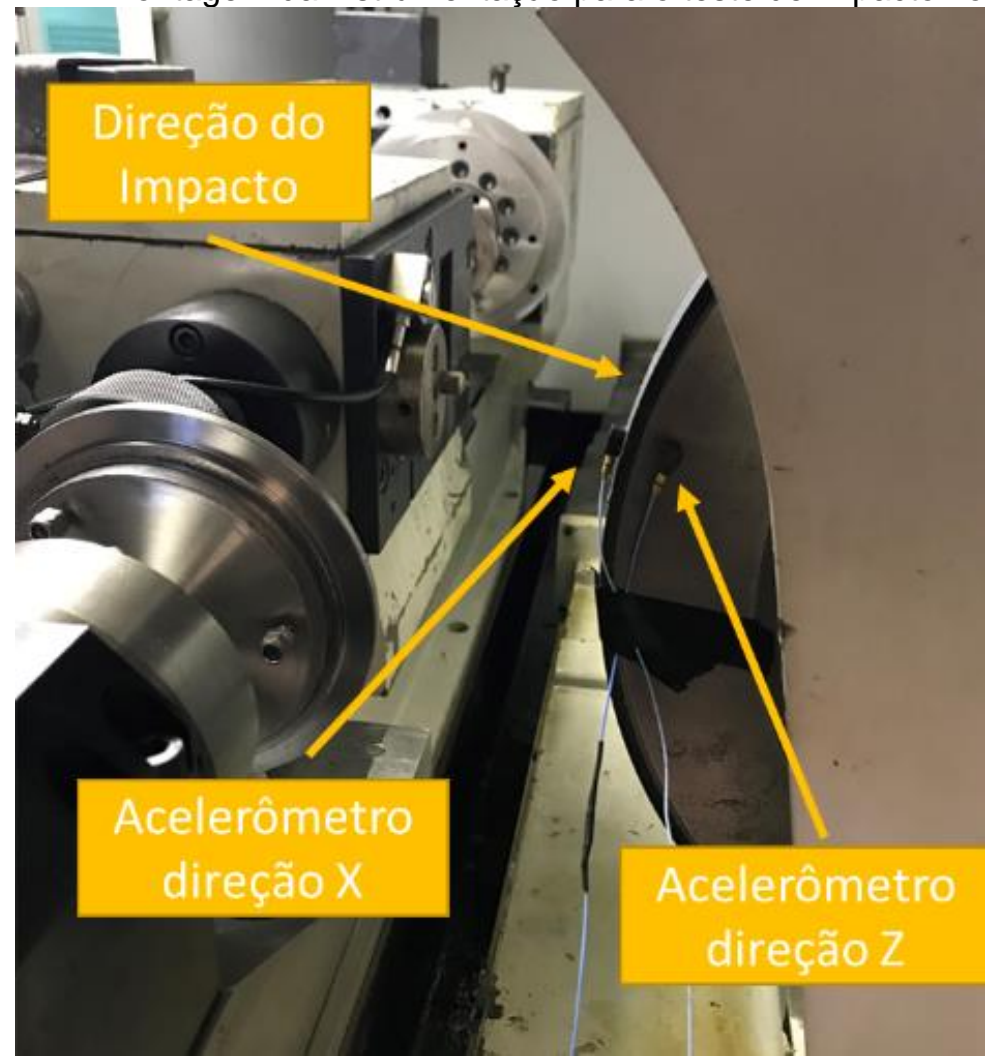

Fonte: Próprio autor. 
A direção $Z$ do disco dressador não foi instrumentada, pois a simulação apontou que a magnitude desse movimento não é relevante. Além disso, pela própria cinemática da dressagem a inclinação do dressador na direção $Z$ não influencia no processo. Esse fenômeno seria análogo a utilização de um dressador montado de maneira não ortogonal à superfície do rebolo.

A aquisição dos dados de aceleração foi feita pela placa SignalCalc Ace em conjunto com o software próprio (SignalCalc Software), da fabricante Data Physics. O sinal foi gerado pelo canal de saída 1 da placa Ace, enquanto os canais de entrada da placa recebiam: no canal 1, o sinal de saída do amplificador (esse sinal se refere ao que sai do amplificador e chega no atuador piezoelétrico); no canal 2, a resposta do acelerômetro do eixo X; e no canal 4, o sinal de saída do amplificador relativo ao sensor de posicionamento do atuador piezoelétrico. Para os testes dinâmicos, tanto de impacto quanto com sinal chirp (sinal sinusoidal cuja frequência varia no tempo), foram feitas duas análises, onde cada uma foi a média de cinco amostras para suavizar os resultados e reduzir os ruídos. Os dados coletados foram exportados no formato do Matlab e em ASCII para análise.

Para obtenção da real frequência natural do sistema, foi enviado para o amplificador do atuador piezoelétrico um sinal chirp de 1V (amplitude), variando de 10 $\mathrm{Hz}$ a $1500 \mathrm{~Hz}$, com duração de 2,56 segundos. Esse método de entrada foi usado, pois é o mais próximo da condição de aplicação. A Figura 4.15 mostra a FRF experimental obtida por meio da aproximação $H_{2}$. A primeira frequência natural $(\omega n)$ ocorre em 421,9 Hz, valor muito próximo ao previsto pela simulação numérica. Os picos menores, que aparecem em $250 \mathrm{~Hz}$ e $600 \mathrm{~Hz}$ são, mais provavelmente, modos locais da retificadora ou da fixação da unidade de dressagem. Portanto, se a frequência adotada para o processo de texturização for próxima a esta frequência natural experimental, uma maior amplitude de dressagem é esperada. 
Figura 4.15 - Comportamento experimental da função de resposta em frequência da unidade dressadora.

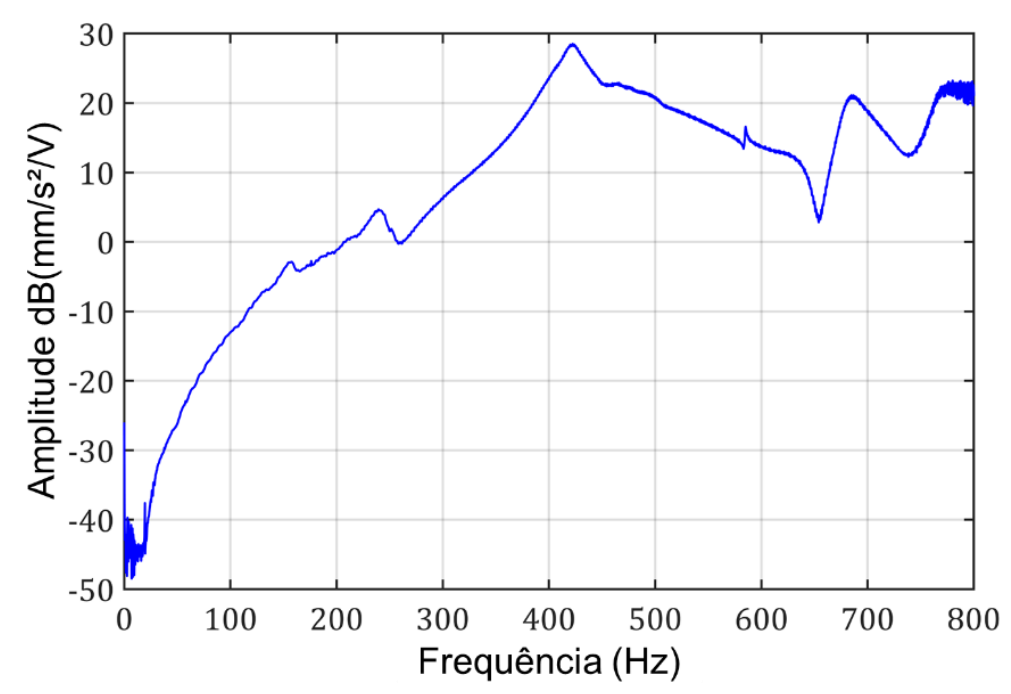

Fonte: Próprio autor.

A Figura 4.16 mostra o gráfico resultante do teste de impacto, onde se pode notar o primeiro modo de vibrar próximo a $420 \mathrm{~Hz}$, valor semelhante ao obtido no ensaio com chirp. Um segundo teste de impacto foi feito, mas agora aplicando uma pré-carga estática no atuador, isto é, alimentando o sistema com uma energia constante a partir do próprio amplificador do piezo, no valor de $500 \mathrm{~V}$ (valor já amplificado). O objetivo desse teste foi descobrir se ao adicionar uma carga, algo que acontece durante a operação de dressagem, haveria alteração no comportamento do sistema. O resultado foi muito similar ao anterior, apresentando um pequeno desvio que não se mostrou relevante.

Figura 4.16 - FRF do teste de impacto realizado na unidade dressadora.

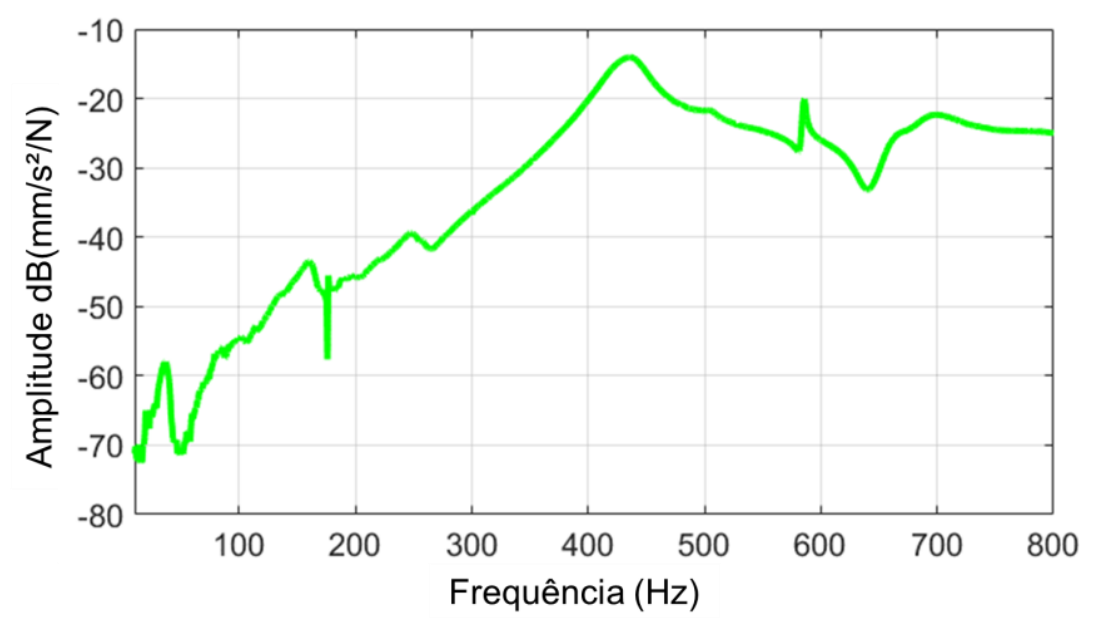

Fonte: Próprio autor. 
O teste de impacto também foi realizado no rebolo de CBN para identificar sua frequência ressonante. A importância dessa medição é evitar excitar o dressador na mesma frequência ressonante do rebolo durante a dressagem. Se o rebolo entrar em ressonância, pode ocorrer a destruição da camada abrasiva da ferramenta.

Figura 4.17 - FRF do teste de impacto no rebolo de CBN.

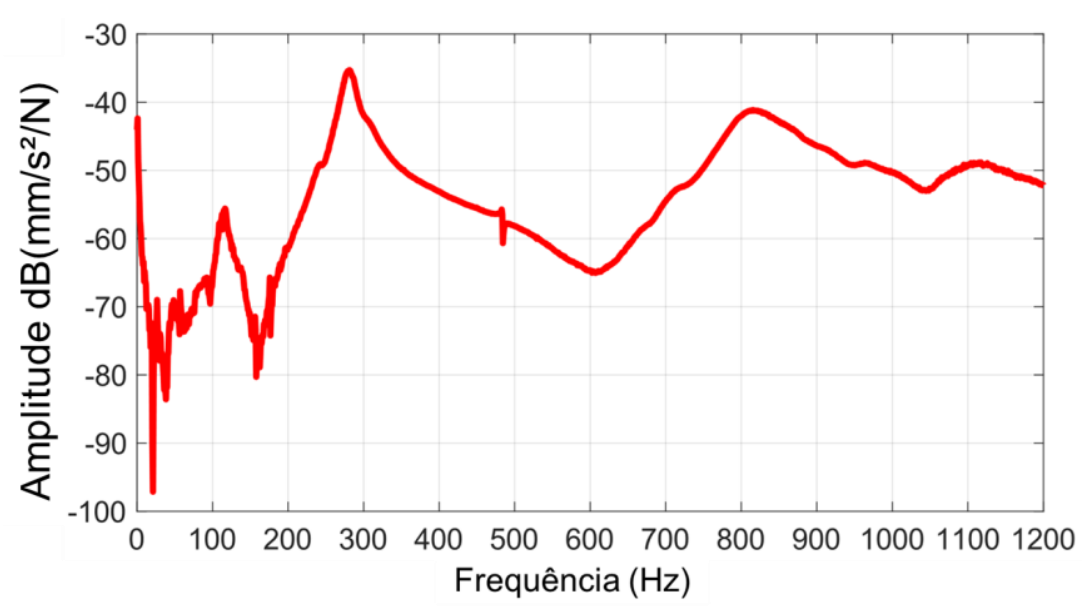

Fonte: Próprio autor.

A Figura 4.17 aponta dois modos de vibrar mais destacados, um em $280 \mathrm{~Hz}$ e outro em $810 \mathrm{~Hz}$. Portanto, deve-se evitar trabalhar em frequências próximas a essas por longos períodos.

A Figura 4.18 é um compilado dos três testes de impacto para ilustrar de forma geral o comportamento do sistema de trabalho, ressaltando que a frequência de interesse $(421,9 \mathrm{~Hz})$ está longe da frequência natural do rebolo, tornando possível a excitação do dressador nessa faixa de frequência. 
Figura 4.18 - FRF dos ensaios de impacto no rebolo e na unidade dressadora.

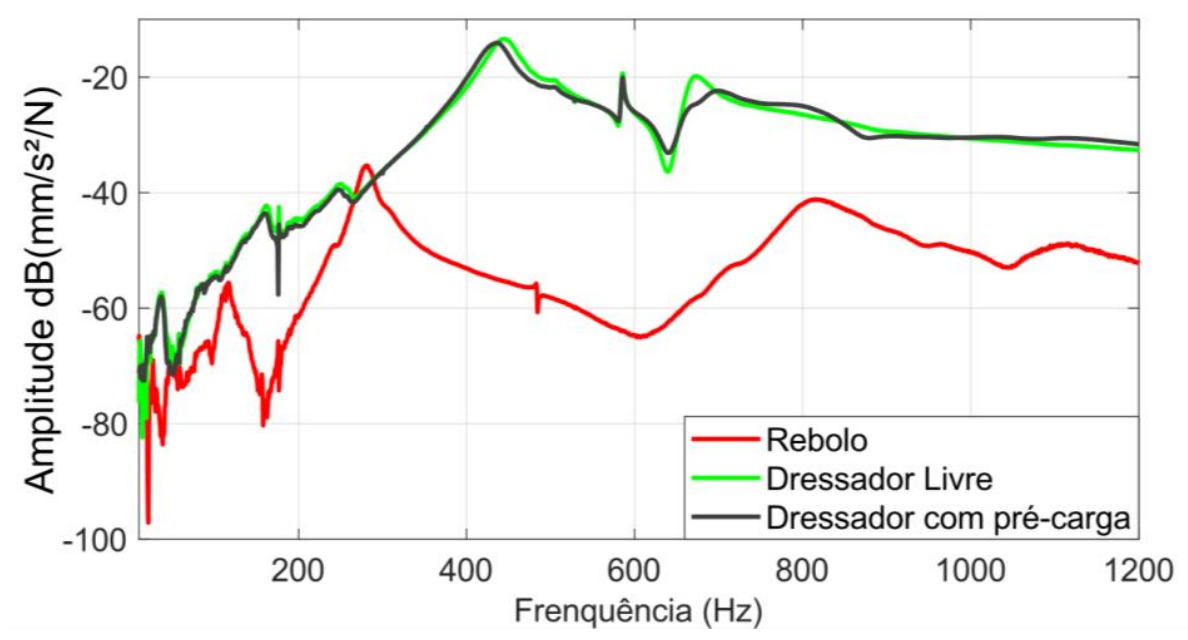

Fonte: Próprio autor.

Uma última análise de vibração foi feita durante a operação de dressagem. Com o acelerômetro ainda posicionado na unidade dressadora, emitiu-se o mesmo sinal chirp já citado, mas agora com o disco em contato com o rebolo, realizando corte. Esse teste é o mais representativo para a condição real de operação, já que não trata os sistemas (rebolo e dressador) isoladamente e considera a interação entre eles. No entanto, o resultado não é representativo. A curva resultante (Figura 4.19) apresenta muitos ruídos, provavelmente oriundos da rotação das ferramentas e da colisão dos grãos abrasivos.

Figura 4.19 - FRF da unidade dressadora durante operação, em contato total com o rebolo.

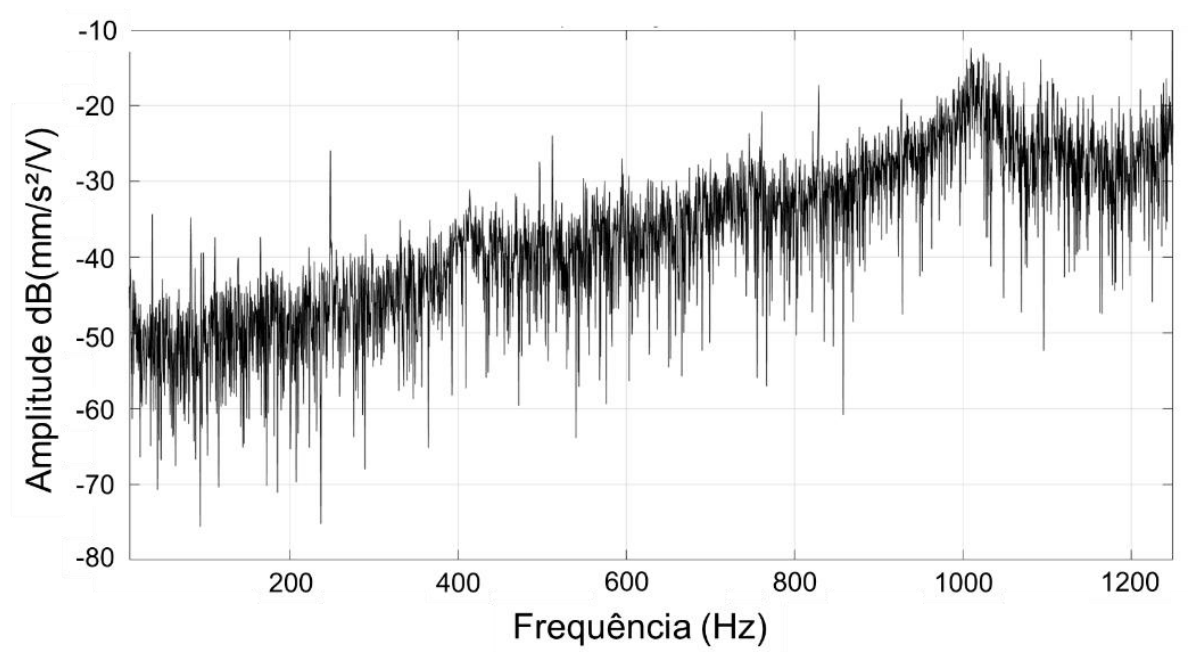

Fonte: Próprio autor. 
Uma análise adicional foi realizada, desacoplando-se o atuador e estrutura de proteção do suporte de mancal flexível (vide Figura 4.9), a fim de se verificar o comportamento do atuador livre, sem as restrições impostas pelo suporte. O ensaio foi feito com um sinal chirp iniciando em zero até uma frequência de $6500 \mathrm{~Hz}$. O sinal de resposta foi coletado de um acelerômetro montado na ponta da haste c, estando a mesma desacoplada do mancal flexível. A Figura 4.22. é a FRF da medição do acelerômetro do atuador e estrutura de proteção desacoplados do suporte do mancal.

Figura 4.20 - FRF do atuador e sua estrutura protetora.

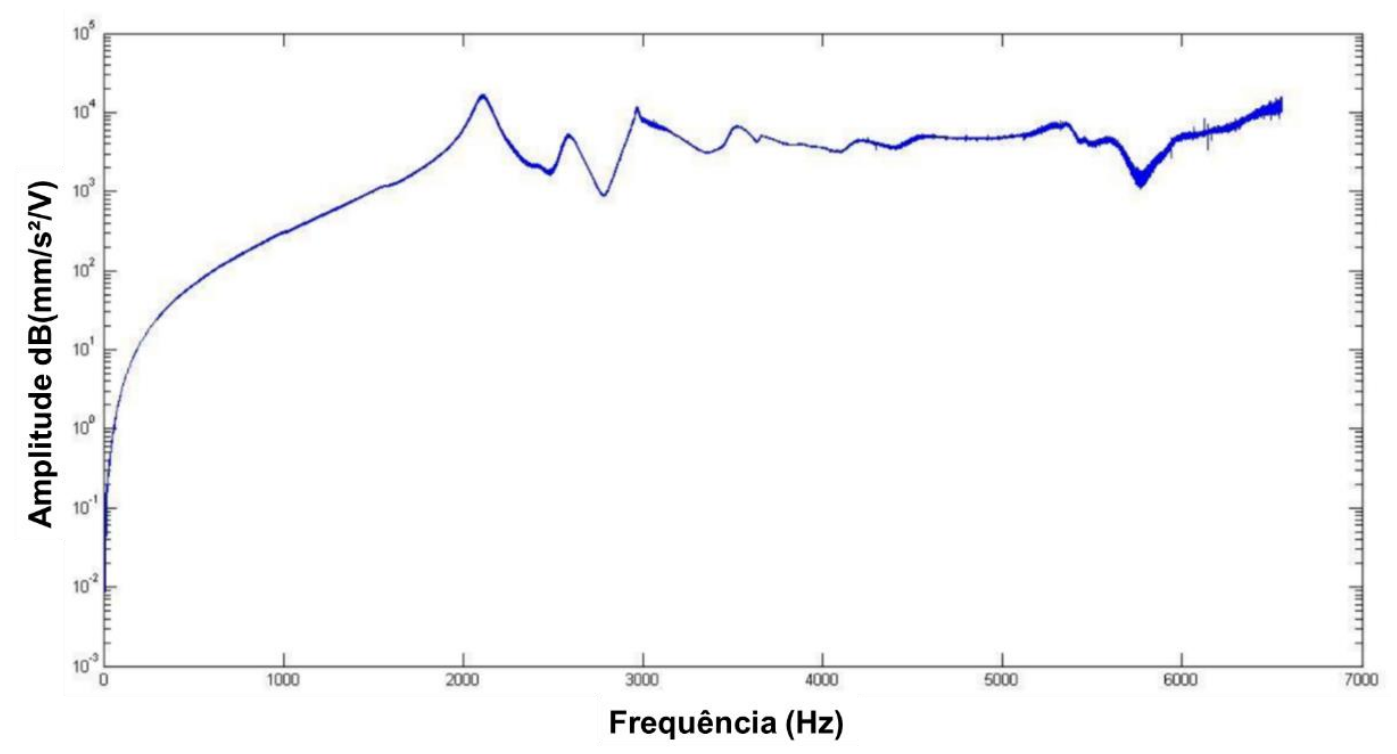

Fonte: Próprio autor.

Comparando-se os resultados da Figura 4.20 e da Figura 4.16, é notável que o comportamento da curva é muito semelhante ao analisado quando o atuador e estrutura de proteção do suporte estão acoplados ao suporte de mancal flexível e este aos demais elementos do sistema (vide Figura 4.6). No caso desacoplado, a primeira frequência ressonante se dá em torno de $2000 \mathrm{~Hz}$. Isso levanta a hipótese de que todo o conjunto mecânico fabricado não altera o comportamento do sistema, apenas altera sua resistência e massa, que reduz o primeiro modo de vibração para 421,9 Hz. Assim o que realmente governa o sistema dinâmico é a estrutura que envolve o atuador. Esse fenômeno não foi avaliado nessa pesquisa, mas pode ser mais bem estudado para uma possível alteração do projeto. 


\subsection{Testes experimentais de texturização por retificação}

Para gerar e transmitir o sinal da textura para o atuador há um sistema de controle da dressagem dinâmica para produção de rampas, desenvolvido em LabView pela equipe de funcionalização de superfícies do LAPRAS. O software conta com uma parte para geração analógica do sinal; recebe a posição angular do rebolo e o sinal de contato; e entradas, onde os dados da parametrização da rampa são inseridos.

O software faz aquisição do sinal analógico RMS de emissão acústica, o que confirma o contato rebolo/disco dressador. Assim que se obtém a informação do contato inicial, a geração de sinal da textura é ativada. A emissão acústica funciona como um gatilho para acionar o programa, isso garante o sincronismo do software. $O$ sincronismo é essencial, pois, como será discutido mais a frente, a texturização é feita em vários passes. Se essa sincronia não existir, cada novo passe apagaria o anterior.

A posição angular do rebolo é obtida a partir do sinal do sensor indutivo instalado no flange do rebolo. Com isso, sabe-se o tempo e o início de cada volta. $O$ sinal de geração da rampa é sempre disparado no começo de cada volta do rebolo.

O software possui um atraso programado, a constante de sincronia. Ele existe por conta da limitação de processamento do software e do hardware. Na prática, a constante de sincronia faz com que uma parte do perímetro do rebolo não seja texturizado.

Uma placa de aquisição e geração de sinais da National Instruments PCI-6040E faz a ligação entre o módulo de EA, o computador com o software de controle e o amplificador do atuador piezoelétrico.

A mesma condição de dressagem (padronização do rebolo) foi usada em todos os testes desse trabalho: razão de esmagamento $q_{d}=+0,4$; profundidade de dressagem $a_{d}=8 \mu \mathrm{m}$; largura do disco dressador $b_{d}=0,3 \mathrm{~mm}$; velocidade de corte $v_{s}=80 \mathrm{~m} / \mathrm{s}$; velocidade longitudinal de dressagem $v_{t}=300 \mathrm{~mm} / \mathrm{min}$; número de passes $z_{d}=4$. A inserção do padrão geométrico na superfície do rebolo durante a dressagem é executada em vários passes para minimizar o desgaste do disco dressador e diminuir a rugosidade da peça pós-retificação, similar à estratégia de touch dressing (KLOCKE, 2009). Como já citado, isso só é possível graças ao sistema de sincronização do software de texturização. Apesar da execução de múltiplos 
passes de dressagem, o tempo total da operação de dressagem é rápido, já que cada passe dura apenas 4 segundos, em razão da velocidade longitudinal de dressagem adotada e a largura do rebolo igual a $20 \mathrm{~mm}$.

A Figura 4.21 ilustra a estratégia de dressagem. O disco dressador é referenciado na superfície do rebolo. A partir daí o disco sempre executa o mesmo movimento, de mesma amplitude, na direção contraria ao rebolo. A cada passe, o rebolo avança sobre o dressador, que remove uma parte do perfil da rampa do perímetro do rebolo. No terceiro passe, teoricamente, o perfil da rampa já estaria completo. Para evitar possíveis erros de posicionamento da máquina e referenciamento do disco, um quarto passe é executado.

Figura 4.21 - Esquema da estratégia de texturização do rebolo por múltiplos passes.



Fonte: Próprio autor.

Ressalta-se que o sistema foi testado e é capaz de realizar a textura em apenas um passe, na profundidade final da textura. Neste teste de verificação, obteve-se profundidade de $16 \mu \mathrm{m}$ na microrampa medida na peça texturizada. Porém, principalmente pelo aumento no desgaste do dressador, essa estratégia foi descartada.

As condições de corte para retificação (texturização) das peças também foram as mesmas em todas as peças descritas nesse trabalho: velocidade periférica do rebolo $\mathrm{v}_{\mathrm{s}}=80 \mathrm{~m} / \mathrm{s}\left(n_{s}=3800 \mathrm{rpm}\right)$; avanço de mergulho $\mathrm{v}_{\mathrm{f}}=0,3 \mathrm{~mm} / \mathrm{min}$; rotação da peça $n_{w}=190 \mathrm{rpm}\left(\mathrm{v}_{\mathrm{w}}=0,45 \mathrm{~m} / \mathrm{s}\right)$; e tempo de centelhamento de 5 voltas 
completas da peça $(3,17 \mathrm{~s})$. A relação de velocidade de rotação entre rebolo e peça $\left(\frac{n_{s}}{n_{w}}\right)$ vale 20 , ou seja, para cada volta completa da peça, o rebolo efetua 20 voltas. Isso significa que todo padrão existente no rebolo será replicado 20 vezes na peça. No caso desse trabalho, apenas um padrão geométrico é inscrito no rebolo e, portanto, todas as peças deverão apresentar 20 microrampas.

Os testes de avaliação do comportamento dinâmico do sistema de dressagem comprovaram o valor da frequência natural do sistema. No entanto, o teste de análise de vibração feito durante a operação de dressagem (vide Figura 4.19) não foi conclusivo. Ainda, seria necessário analisar a resposta da unidade dressadora, não mais com um sinal chirp, mas sim com o sinal de geração da microrampa.

Para isso, foi realizado um ensaio de calibração. Enviando o sinal da microrampa na proporção de interesse (1:5) e com amplitude inicial de 1V, que, teoricamente (pelo manual do fabricante), para o atuador livre, representa um deslocamento de $12 \mu \mathrm{m}$ na direção radial. O objetivo da calibração é encontrar a relação entre a tensão de entrada no amplificador do piezo e a amplitude da textura gerada na peça.

A amplitude obtida para o caso de interesse (proporção de 1:5) foi da ordem de $7 \mu \mathrm{m}$. Anteriormente (seção 4.2), foi mostrado o comportamento do conjunto amplificador-atuador, ressaltando a queda de resposta do sistema em frequências superiores a $100 \mathrm{~Hz}$. Isso pode ser observado neste resultado. Portanto, para obtenção de uma profundidade maior da textura no rebolo, é necessário proporcionar mais energia ao sistema. Como resultado da calibração para obtenção da amplitude desejada, de $12 \mu \mathrm{m}$, um sinal com tensão de entrada superior a $1 \mathrm{~V}$ deve ser enviado ao amplificador do atuador.

Três diferentes tensões de entrada do amplificador foram testadas, retificandose peças posteriormente. O Quadro 2-1 alinha as tensões testadas e as profundidades medidas nas peças. 
Quadro 4-2 - Testes para calibração do sistema.

\begin{tabular}{|l|c|c|c|c|}
\hline Amplitude de geração do sinal (V) & 1,00 & 1,25 & 1,50 & 1,75 \\
\hline Profundidade da textura na peça $(\boldsymbol{\mu m})$ & 7,00 & 9,30 & 12,10 & 14,60 \\
\hline
\end{tabular}

Fonte: Próprio autor.

Com os resultados apresentados, a calibração foi concluída. A tensão de entrada de 1,5 V é a ideal para se obter a profundidade de textura desejada, já que gerou uma profundidade de $12 \mu \mathrm{m}$ na peça. A Figura 4.22 expõe a medição da textura gerada com essa tensão. À esquerda, mostra-se o perfil circular e à direita, o mesmo perfil linearizado com ampliação em uma das rampas. Nota-se a profundidade medida de $12 \mu \mathrm{m}$, além da forma da textura, a parte com maior inclinação e a outra parte com menor inclinação. Observa-se também que as 20 rampas desejadas foram formadas.

Figura 4.22 - Medição de circularidade da peça texturizada com rampa de proporção 1:5 e profundidade de $12 \mu \mathrm{m}$.
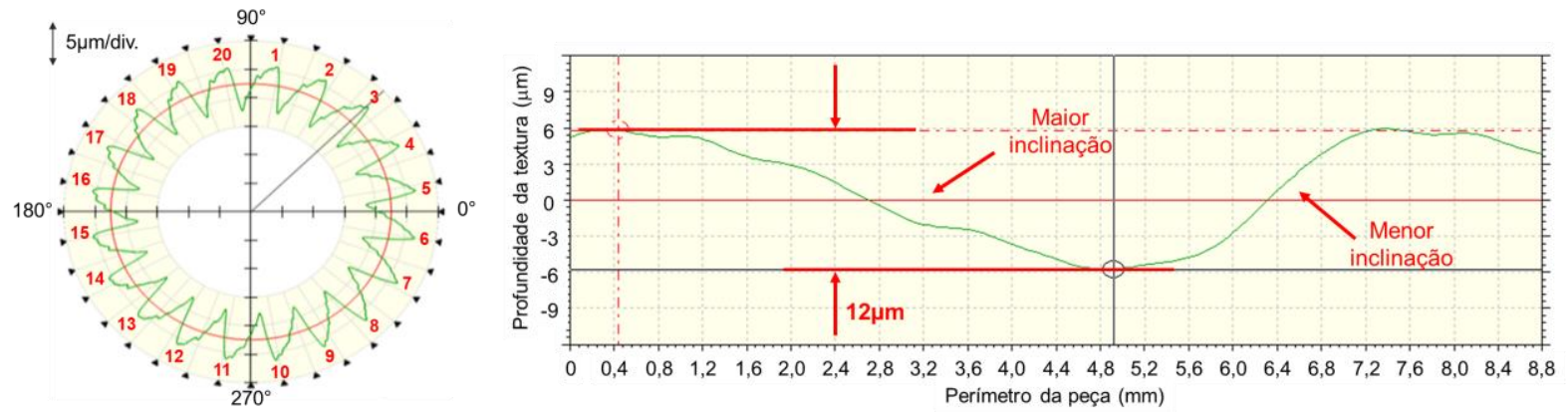

Fonte: Próprio autor.

Com os testes de calibração definiu-se as condições ideais para a fabricação das microrampas com a geometria desejada. 


\section{RESULTADOS E DISCUSSÕES}

A unidade de dressagem fabricada tem seu primeiro modo de vibrar experimentalmente medido em $421,9 \mathrm{~Hz}$, valor muito próximo à frequência de excitação para fabricação das texturas em forma de microrampa na proporção de 1:5, cujo valor é $414 \mathrm{~Hz}$.

A medição de peças texturizadas mostrou que a unidade é capaz de inscrever na superfície do rebolo de CBN com ligante vitrificado o padrão geométrico no formato de microrampa desejado, considerando-se as inclinações e profundidade de projeto.

Nesse capítulo, mostra-se o comportamento da unidade dressadora operando em frequências diferentes da natural para comprovar a otimização de resposta prevista. Há também uma comparação da medição de peças texturizadas com predições feitas pelo software de simulação de texturas desenvolvido pelo grupo de pesquisa em Funcionalização de Superfícies (SILVA et al., 2016). Esse simulador foi modificado para incorporar as restrições da cinemática de contato entre disco dressador e rebolo (SILVA et al., 2018).

\subsection{Testes de texturização por retificação}

A análise de resposta em frequência da seção 4.4 mostrou a frequência natural da unidade dressadora de 421,9 Hz. Faz-se necessário comprovar que essa frequência de excitação tem real influência na fabricação de texturas. Para isso, cinco perfis foram avaliados. As frequências associadas a cada perfil estão descritas no Quadro 5-1, sendo que a maior frequência na proporção 1:5 é a mais próxima da frequência natural do sistema. A primeira onda seno indica a porção de menor inclinação da microrampa, enquanto a segunda onda seno corresponde à inclinação mais acentuada, a representação dessas ondas é exposta na Figura 3.4 e uma explicação mais detalhada, na seção 3.2.1. 
Quadro 5-1 - Proporções e frequências de geração do sinal da microrampa.

\begin{tabular}{|c|c|c|}
\hline $\begin{array}{c}\text { Proporção da } \\
\text { microrampa }\end{array}$ & $\begin{array}{c}\text { Frequência da primeira } \\
\text { onda seno } \mathbf{( H z})\end{array}$ & $\begin{array}{c}\text { Frequência da segunda } \\
\text { onda seno } \mathbf{( H z})\end{array}$ \\
\hline $1: 3$ & 92,0 & 276,0 \\
\hline $1: 4$ & 86,0 & 345,0 \\
\hline $1: 5$ & 83,0 & 414,0 \\
\hline $1: 6$ & 80,6 & 483,0 \\
\hline $1: 7$ & 79,0 & 553,0 \\
\hline
\end{tabular}

Fonte: Próprio autor.

A avaliação do real deslocamento do dressador foi efetuada medindo-se a amplitude das microrampas na superfície das peças retificadas para cada proporção testada. O sinal gerado para todos os casos foi de $1 \mathrm{~V}$ na entrada do amplificador. A amplitude das texturas foi obtida por medições de circularidade, assim como a medição apresentada na Figura 4.22. Tais amplitudes são representadas pelos pontos vermelhos na Figura 5.1. Para efeito de comparação, o gráfico de resposta em frequência do sistema de dressagem também é apresentado na figura 5.1.

Figura 5.1. - Profundidade da textura medida na peça retificada para diferentes proporções de rampa e FRF do comportamento do sistema

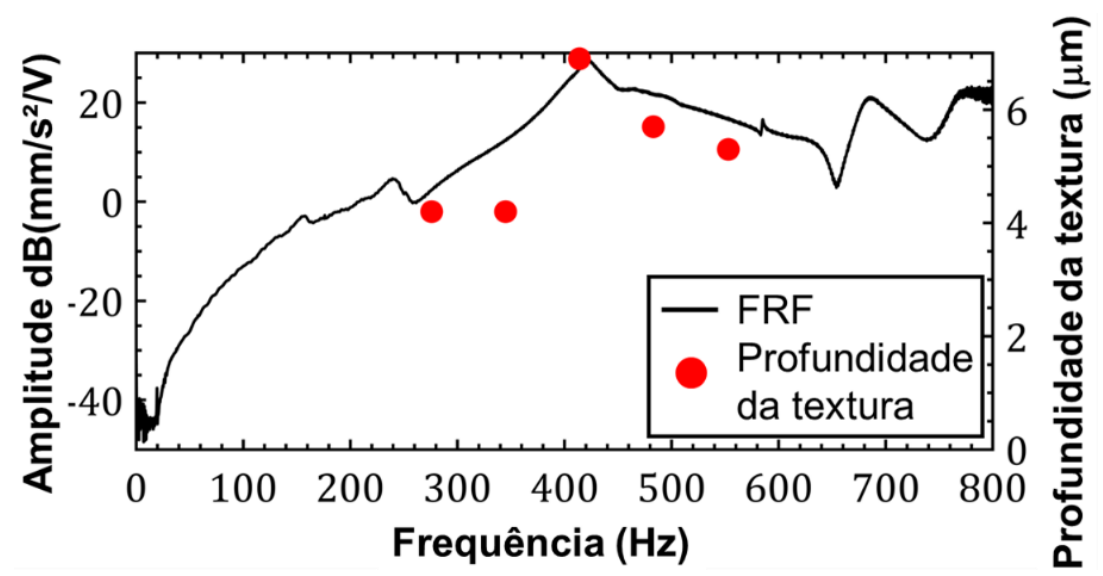

Fonte: (SILVA et al., 2018), adaptado pelo autor.

Pode-se notar que as profundidades das texturas tiveram comportamento similar à curva de resposta em frequência do sistema (FRF). A proporção 1:5 (frequência mais próxima à natural) gerou uma profundidade maior na peça retificada se comparada às proporções de 1:3 e 1:4 (frequências mais baixas); e 1:6 e 1:7 (frequências mais altas). 
Com isso, comprova-se o melhor desempenho do sistema, para o caso proposto, quando atua próximo à sua frequência natural, na proporção de interesse (1:5).

O critério de projeto para produzir microrampas com proporção 1:5 foi simulado utilizando uma versão adaptada do software de simulação apresentado no trabalho de Silva et al. (2016). A análise do contato da ferramenta de dressagem, inicialmente modelado para ferramentas de ponta única, foi adaptado para considerar o arco resultante do contato do disco dressador com o rebolo. Assim, a restrição imposta pela dinâmica do contato entre rebolo e disco dressador pode ser prevista (SILVA et al., 2018).

O perfil desejado não é completamente adquirido devido a uma combinação de características dinâmicas e geométricas das ferramentas envolvidas (disco dressador e rebolo) e da peça. Esses efeitos são mostrados na Figura 5.2. Nota-se que as maiores limitações do processo são decorrentes dessas características geométricas de contato (curva em azul) e dinâmicas da unidade dressadora (curva em laranja). A unidade projetada é capaz de realizar os movimentos necessários para geração da textura, mas a geometria da rampa, tanto no rebolo, quanto na peça, sofre um arredondamento. Este aparece na parte de maior inclinação da rampa, já que é a parte em que o disco deve avançar, quase que perpendicularmente contra a superfície do rebolo, e, portanto, a geometria circular do disco exerce grande influência no vale da rampa. No entanto, esses efeitos não comprometem a profundidade da textura, apenas sua forma. 
Figura 5.2 - Perfil da microrampa gerada, simulada e medida.

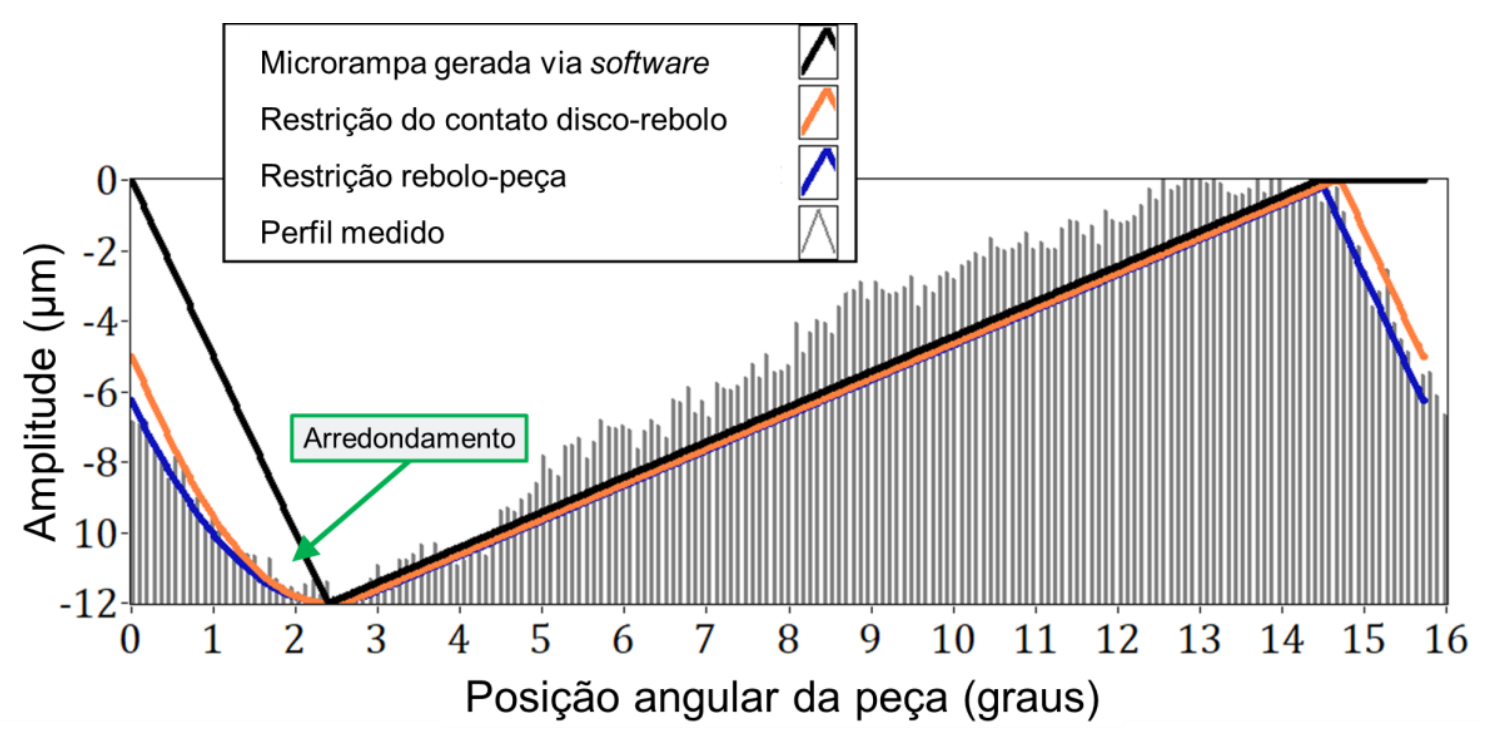

Fonte: (SILVA et al., 2018), adaptado pelo autor.

Silva et al. (2016) mostra que o arredondamento só aparece quando a textura é transferida para a peça, pois é o único momento em que o contato é uma intersecção de dois círculos, já que o dressador utilizado naquela pesquisa era de ponta única (Figura 5.3). De qualquer forma, um pequeno arredondamento é notório, pois, apesar da geometria retilínea do dressador, de ser quase um ponto de contato, de valor máximo igual à largura de atuação do dressador em função da profundidade de dressagem utilizada, a trajetória do movimento dressador-rebolo é circular.

Figura 5.3 - Três perfis consecutivos de microrampa gerada, simulada e medida referentes a um dressador de ponta única com bd de 0,6 $\mu \mathrm{m}$.

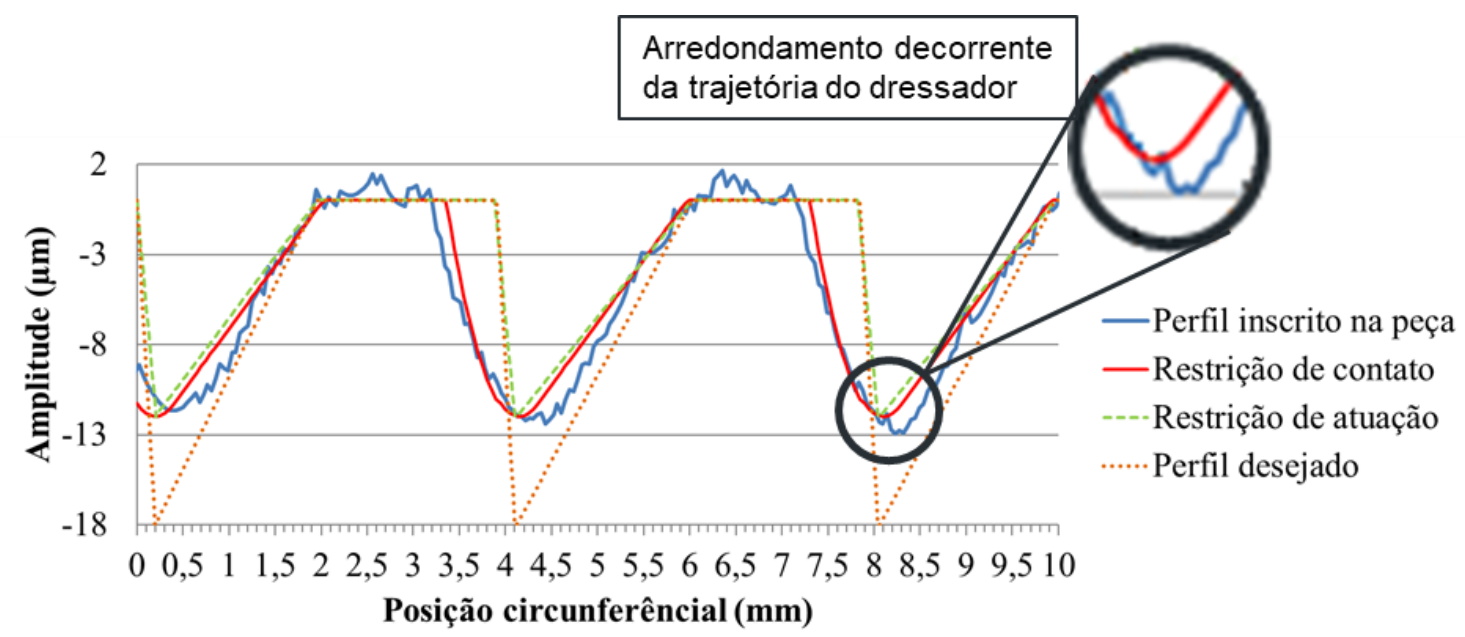

Fonte: ( SILVA et al., 2016), adaptado pelo autor. 
O modelo dinâmico com disco dressador foi simulado e comparado à medição do perfil circular da textura de proporção 1:5, como mostrado na Figura 5.4. Comparando a medição à simulação, conclui-se que a modificação do simulador para o contato disco-rebolo apresenta resultados confiáveis. Nota-se que a forma das rampas no perfil medido e no perfil simulado são semelhantes, bem como a profundidade das texturas nos dois casos e o número de microrampas formadas.

Figura 5.4 - Circularidade medida e simulada para a rampa de 1:5.

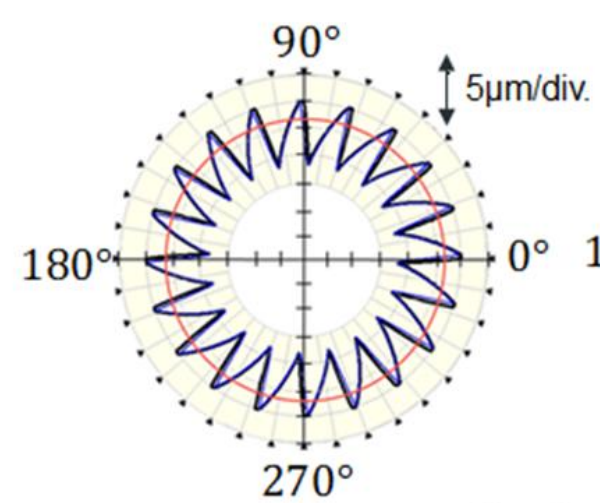

Rampa gerada

via software

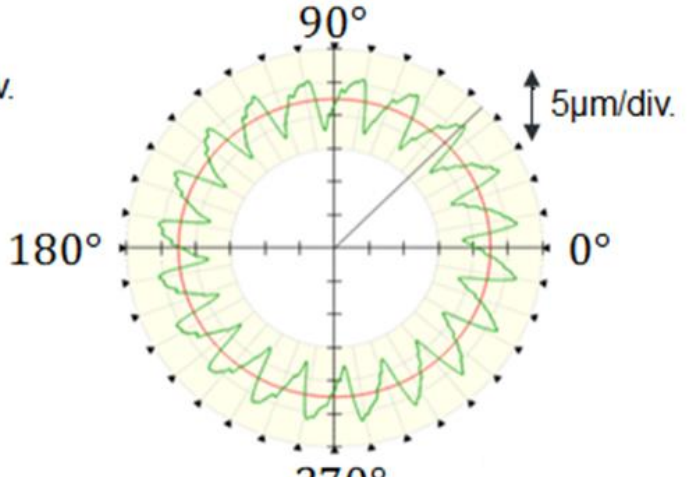

$270^{\circ}$

Fonte: Próprio autor.

A Figura 5.5 é uma peça produzida para facilitar a visualização das texturas. A descrição da peça e condições de texturização estão descritas no capítulo 4. Em dois colos foram introduzidas defasagens no sinal de geração da rampa em intervalos de distância na direção axial, para produzir o efeito de tabuleiro de xadrez. O terceiro colo é uma textura normal, sem o efeito de xadrez, de proporção 1:5, como a da Figura 4.22, porém com menor profundidade. Na Figura 5.6, há uma ampliação de um dos colos e uma medição adicional feita no perfilômetro, na direção axial da peça (adotouse um comprimento de medição de $15 \mathrm{~mm}$ e a medição obtida representa o perfil bruto de rugosidade). O resultado da medição é uma profundidade entre pico e vale de 6 $\mu \mathrm{m}$ e a medida foi realizada no ponto de maior profundidade da textura, na região mais baixa da microrampa. Para melhorar a visualização das texturas, a peça foi pintada com um marcador azul e submetida a uma operação de polimento fino. 
Figura 5.5 - Peça texturizada preparada para melhor visualização das microrampas.

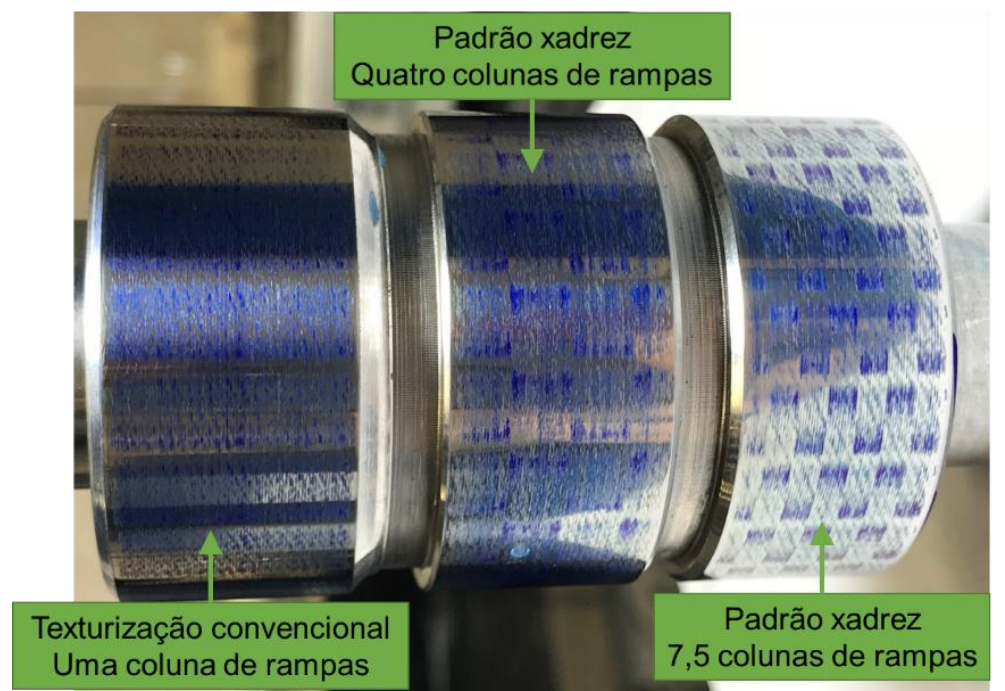

Fonte: Próprio autor.

Figura 5.6 - Medida na direção axial do perfil da microrampa de 1:5 em padrão xadrez

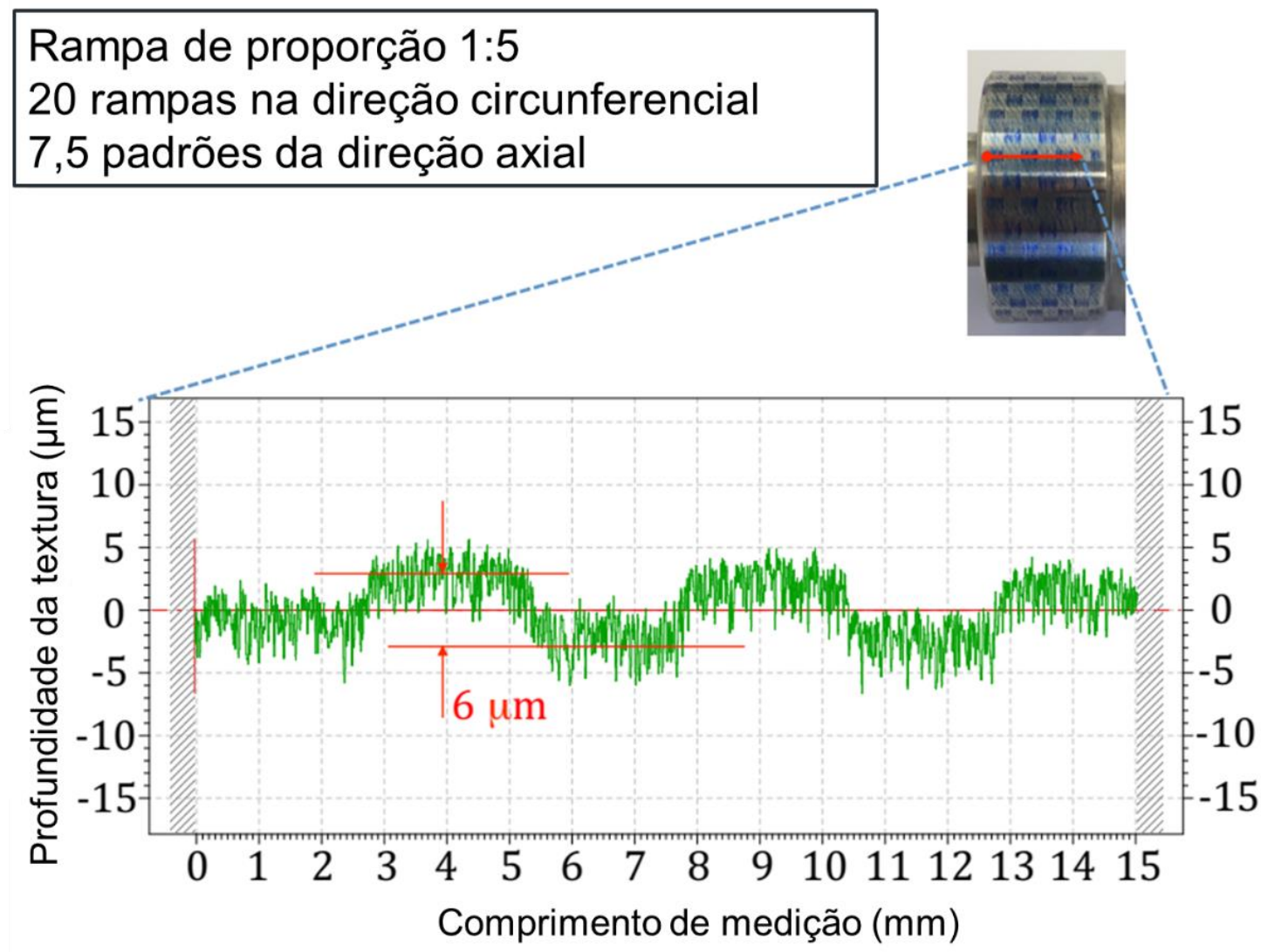

Fonte: (SILVA et al., 2018), adaptado pelo autor. 
Todas as texturas produzidas têm a mesma forma, a microrampa. Isso foi feito para validar o projeto proposto, mostrando que a unidade dressadora é capaz de inserir um padrão do tipo microrampa na superfície de um rebolo de CBN vitrificado, utilizando um disco diamantado. A produção de texturas com geometrias diferentes é possível com essa mesma unidade, no entanto, se as frequências de excitação forem diferentes da frequência natural, a resposta do sistema será atenuada. Contudo, as simulações da seção 4.3 mostram que alterações nas dimensões $a$ e $b$ do projeto (Figura 4.6) podem aumentar ou diminuir a frequência natural do sistema. Portanto, se houver interesse em executar outros tipos de texturas, com outras frequências de excitação, pode-se adaptar o projeto para que a unidade dressadora tenha sua resposta otimizada.

Vale salientar que várias partes de todo o sistema desenvolvido acumulam perdas de amplitude que refletem na textura final. O fluxograma da Figura 5.7 mostra potenciais pontos de perda de energia. Alguns desses pontos foram confirmados com medições auxiliadas por um osciloscópio.

Figura 5.7 - Potenciais pontos de perda de energia no sistema de texturização.

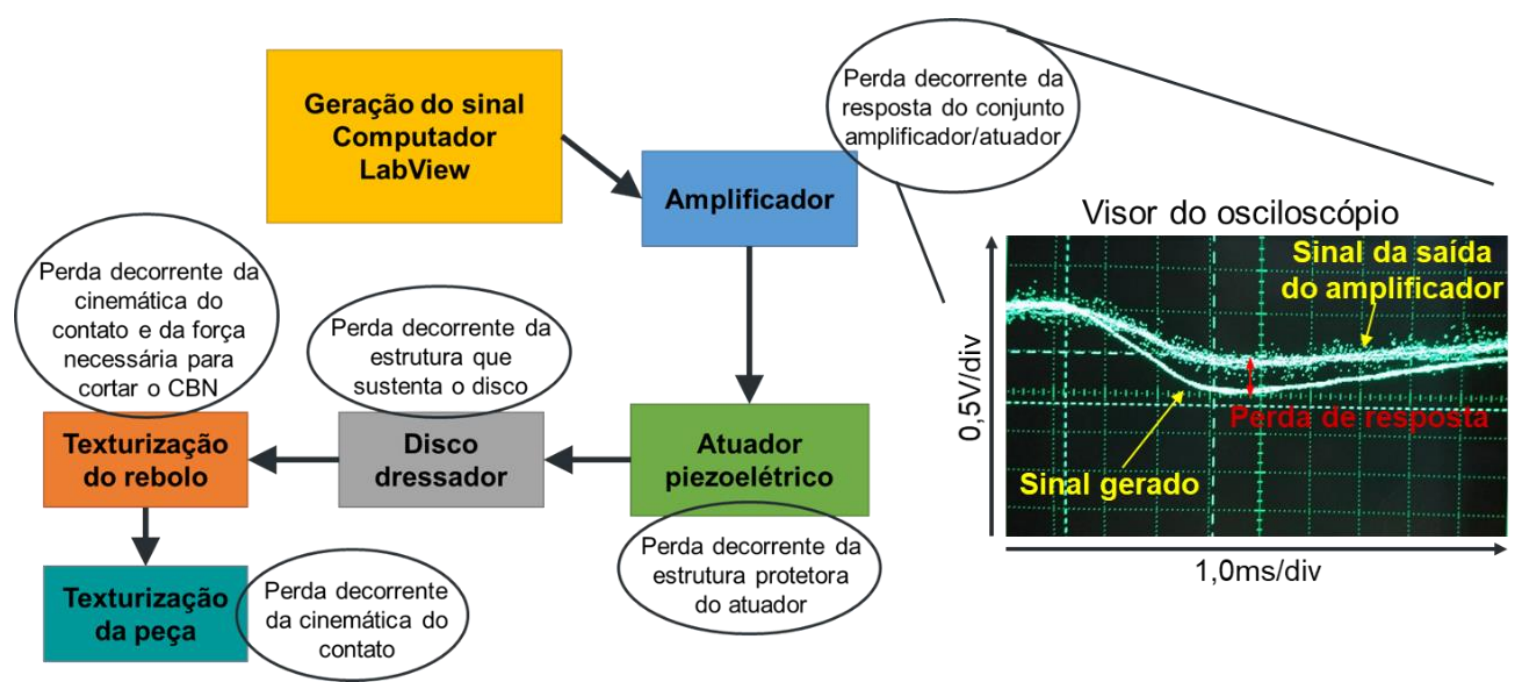

Fonte: Próprio autor.

Com relação às medições efetuadas, algumas considerações são pertinentes. Uma medida de interesse é a topologia do rebolo pós dressagem para inserção dos padrões geométricos. Tal informação traria a confirmação total do simulador de contato e poderia mostrar uma influência maior da oscilação na frequência natural do sistema. $\mathrm{O}$ autor não conseguiu realizar uma medida confiável da superfície do rebolo 
com os equipamentos que the eram disponíveis. A estratégia utilizada para padronização do rebolo envolve a inscrição de uma única microrampa ao longo de todo comprimento circunferencial do rebolo, ou seja, para um rebolo de $400 \mathrm{~mm}$ de diâmetro, tem-se uma textura com profundidade máxima esperada de $12 \mu \mathrm{m}$ e um comprimento de $1256 \mathrm{~mm}$. A profundidade da textura é muito menor que o seu comprimento, sendo impossível de se enxergar a olho nu. Esse fato dificulta muito a medição direta da microrampa no rebolo. Tentou-se medir com um transdutor para medição de deslocamento linear, mas sem sucesso. A medida do transdutor variou muito apenas pelo contato com os grãos de CBN. Outra tentativa foi texturizar apenas metade do rebolo e copiar o perfil para uma chapa metálica que posteriormente foi medida buscando uma diferença de altura das duas áreas, mas também não se obteve resultados confiáveis. Existe uma técnica para medição da topologia do rebolo que envolve a aplicação de uma resina em uma porção da superfície do rebolo. Depois de aplicada, a resina endurece e retém a forma da superfície do rebolo. Ela é então retirada e analisada em um medidor de perfil. No entanto, para o caso desse trabalho, seria necessário aplicar a resina por todo o comprimento circunferencial do rebolo o que dificultaria a posterior remoção da resina. Além disso, a resina teria uma forma final circular, impedindo o uso de um perfilômetro para medição, seria necessário usar um medidor de circularidade capaz de medir um diâmetro de $400 \mathrm{~mm}$. Por conta das dificuldades destacadas, a utilização da resina foi descartada. A medição da profundidade dos padrões geométricos no rebolo com o auxílio do mapa de EA, poderia ser uma estratégia viável para a inspeção da profundidade, como utilizado por Silva et al. (2016), quando da utilização de um sistema de dressagem com dressador tipo ponta única. Todavia, para o caso do rebolo de CBN vitrificado e dressador rotativo, o mapa de emissão acústica não proveu informações confiáveis. Ruídos acústicos gerados pelos rolamentos presentes no mancal flexível e na unidade dressadora, possíveis desbalanceamentos e o contato de vários grãos entre disco e rebolo trouxeram ruídos para o mapa acústico e não foi possível identificar com precisão o padrão gerado no rebolo. 


\section{CONCLUSÕES}

As principais conclusões desse trabalho são:

- Foi possível produzir por retificação peças texturizadas com perfil hidrodinâmico, utilizando-se um rebolo de CBN com ligante vitrificado, com padrões geométricos inscritos em sua superfície durante a operação de dressagem, utilizando-se disco dressador diamantado rotativo.

- O problema de movimentar a grande massa do sistema de dressagem foi superado por um novo projeto no qual se adicionou flexibilidade estrutural para ajustar a frequência natural do sistema e diminuir a massa a ser movida.

- É possível projetar uma unidade de dressagem baseada em análise modal, levando-se em conta o comportamento dinâmico do sistema, a fim de se maximizar a amplitude de resposta quando da operação próxima à frequência natural.

- A unidade é limitada para as características de textura e retificação descritas no trabalho. Para diferentes geometrias de textura, necessidade de mais de um padrão no rebolo, rebolo de outro diâmetro ou mudança da velocidade periférica, as frequências de atuação mudam. Portanto, é necessário reprojetar o sistema para mudar sua frequência natural.

- A padronização do rebolo é mais demorada que uma dressagem convencional, uma vez que são necessários múltiplos passes para gerar a textura com a geometria desejada. Isso também implica em um maior consumo do rebolo. 


\section{SUGESTÕES PARA TRABALHOS FUTUROS}

- Desenvolver um método para medição dos padrões geométricos inscritos no rebolo.

- Medir as peças texturizas em um medidor sem contato para eliminar possíveis distorções oriundas o do apalpador de medição.

- Utilizar um spindle com sensor de Aa embutido para geração de um mapa acústico menos ruidoso.

- Reduzir o arco de contato entre disco dressador e rebolo para avaliar a possível melhora na geometria da textura.

- Utilizar a unidade dressadora para texturas de outras geometrias.

- Avaliar se o comportamento dinâmico da unidade é regido pelo conjunto atuador piezoelétrico e sua estrutura de proteção.

- Alterar o projeto, adicionando algum elemento capaz de alterar a frequência natural do sistema sem a necessidade de se fabricar novas peças. 


\section{REFERÊNCIAS BIBLIOGRÁFICAS}

ABDEL-AAL, H. A. Functional surfaces for tribological applications: Inspiration and design. Surface Topography: Metrology and Properties, v. 4, n. 4, 2016.

AMPLIFIER, H. P.; RECOVERY, E. PZ170E User Manual E-481 High-Performance Piezo Amplifier / Controller. 2013.

AURICH, J. C.; BRAUN, O.; WARNECKE, G.; CRONJÄGER, L. Development of a Superabrasive Grinding Wheel With Defined Grain Structure Using Kinematic Simulation. CIRP Annals, v. 52, n. 1, p. 275-280, 2003. Disponível em: <http://linkinghub.elsevier.com/retrieve/pii/S0007850607605836>.

BHADURI, D.; BATAL, A.; DIMOV, S. S.; ZHANG, Z.; DONG, H.; FALLQVIST, M.; M'SAOUBI, R. On Design and Tribological Behaviour of Laser Textured Surfaces. Procedia CIRP, v. 60, p. 20-25, jan. 2017.

BORGHI, a.; GUALTIERI, E.; MARCHETTO, D.; MORETTI, L.; VALERI, S. Tribological effects of surface texturing on nitriding steel for high-performance engine applications. Wear, v. 265, n. 7-8, p. 1046-1051, 2008.

BOTTENE, A. C. Método Inovador para Texturização de Rebolos. 2012. Universidade de São Paulo, 2012.

BRAUN, D.; GREINER, C.; SCHNEIDER, J.; GUMBSCH, P. Efficiency of laser surface texturing in the reduction of friction under mixed lubrication. Tribology International, v. $77, \quad$ n. June 2015 , p. 142-147, 2014. Disponível em: <http://dx.doi.org/10.1016/j.triboint.2014.04.012>.

BRUZZONE, A. A. G.; COSTA, H. L.; LONARDO, P. M.; LUCCA, D. A. Advances in engineered surfaces for functional performance. CIRP Annals - Manufacturing Technology, v. 57, n. 2, p. 750-769, 2008.

CHAVOSHI, S. Z.; GOEL, S.; MORANTZ, P. Current trends and future of sequential micro-machining processes on a single machine tool. Materials and Design, v. 127, n. April, p. 37-53, 2017. Disponível em: 
<http://dx.doi.org/10.1016/j.matdes.2017.04.057>.

CHO, C.; KIM, H.; JEONG, S.; BAEK, S. W.; SEO, J. W.; HAN, D.; KIM, K.; PARK, Y.; YOO, S.; LEE, J. Y. Random and V-groove texturing for efficient light trapping in organic photovoltaic cells. Solar Energy Materials and Solar Cells, v. 115, p. 36-41, 2013. Disponível em: <http://dx.doi.org/10.1016/j.solmat.2013.03.014>.

CHOWDHURY, M. A. K.; KUBO, A.; TAMAKI, J.; ULLAH, A. M. M. S. Computer-aided Simulation of Rotary Diamond Dressing Based on Kinematic Analysis. Journal of Advanced Mechanical Design, Systems, and Manufacturing, v. 7, n. 4, p. 506520, 2013.

Disponível

em: <http://jlc.jst.go.jp/DN/JST.JSTAGE/jamdsm/7.506?lang=en\&from=CrossRef\&type=a bstract>.

COBLAS, D. G.; FATU, A.; MAOUI, A.; HAJJAM, M. Manufacturing textured surfaces: State of art and recent developmentsProceedings of the Institution of Mechanical Engineers, Part J: Journal of Engineering TribologySAGE PublicationsSage UK: London, England, , jan. 2015. .

COSTA, H. L.; HUTCHINGS, I. M. Hydrodynamic lubrication of textured steel surfaces under reciprocating sliding conditions. Tribology International, v. 40, n. 8, p. 12271238, ago. $2007 . \quad$ Disponível em: <http://www.sciencedirect.com/science/article/pii/S0301679X0700014X>. Acesso em: 14 dez. 2015.

COSTA, H. L.; HUTCHINGS, I. M. Effects of die surface patterning on lubrication in strip drawing. Journal of Materials Processing Technology, v. 209, n. 3, p. 11751180, 2009.

DENKENA, B.; KÄSTNER, J.; WANG, B. Advanced microstructures and its production through cutting and grinding. CIRP Annals - Manufacturing Technology, v. 59, n. 1, p. 67-72, 2010. Disponível em: <http://dx.doi.org/10.1016/j.cirp.2010.03.066>.

ETSION, I. State of the Art in Laser Surface Texturing. Journal of Tribology, v. 127, n. $1, \quad$ p. 248,2005 Disponível em: <http://tribology.asmedigitalcollection.asme.org/article.aspx?articleid=1467274>. ETSION, I. Modeling of surface texturing in hydrodynamic lubrication. Friction, v. 1, n. 
3, p. 195-209, 20 set. 2013. Disponível em: <http://link.springer.com/10.1007/s40544013-0018-y>.

EVANS, C. J.; BRYAN, J. B. "Structured", "Textured" or "Engineered" Surfaces. CIRP Annals - Manufacturing Technology, v. 48, n. 2, p. 541-556, 1999.

GACHOT, C.; ROSENKRANZ, A.; HSU, S. M.; COSTA, H. L. A critical assessment of surface texturing for friction and wear improvement. Wear, v. 372-373, p. 21-41, fev. 2017. Disponível em:

<http://linkinghub.elsevier.com/retrieve/pii/S0043164816307013>.

GALDA, L.; PAWLUS, P.; SEP, J. Dimples shape and distribution effect on characteristics of Stribeck curve. Tribology International, v. 42, n. 10, p. 1505-1512, 2009. Disponível em: <http://dx.doi.org/10.1016/j.triboint.2009.06.001>.

GROPPER, D.; WANG, L.; HARVEY, T. J. Hydrodynamic lubrication of textured surfaces: A review of modeling techniques and key findings. Tribology International, v. 94, p. 509-529, fev. 2016. Disponível em: <http://linkinghub.elsevier.com/retrieve/pii/S0301679X15004582>.

IBATAN, T.; UDDIN, M. S.; CHOWDHURY, M. A. K. Recent development on surface texturing in enhancing tribological performance of bearing sliders. Surface and Coatings Technology, v. 272, p. 102-120, 2015. Disponível em: <http://dx.doi.org/10.1016/j.surfcoat.2015.04.017>.

JACKSON, M. J.; DAVIM, J. P. Machining with Abrasives. Boston, MA: Springer US, 2011.

KHANGAR, A.; DAHOTRE, N. B. Morphological modification in laser-dressed alumina grinding wheel material for microscale grinding. Journal of Materials Processing Technology, v. 170, n. 1-2, p. 1-10, dez. 2005. Disponível em: <http://linkinghub.elsevier.com/retrieve/pii/S0924013605005212>.

KLOCKE, F. Manufacturing Processes 2. Berlin, Heidelberg: Springer Berlin Heidelberg, 2009.

LI, H. N.; AXINTE, D. Textured grinding wheels: A review. International Journal of Machine Tools and Manufacture, v. 109, p. 8-35, out. 2016. Disponível em: 
<http://linkinghub.elsevier.com/retrieve/pii/S089069551630075X>.

MALKIN, S.; GUO, C. Grinding Technology: Theory and Application of Machining with Abrasives. [s.I.] Industrial Press Inc., 2008.

MASUZAWA, T. State of the Art of Micromachining. CIRP Annals, v. 49, n. 2, p. 473488, 2000.2 Disponível em: <http://linkinghub.elsevier.com/retrieve/pii/S0007850607634519>.

MORONUKI, N. Functional Texture Design and Texturing Processes. International Journal of Automation Technology, v. 10, n. 1, p. 4-15, 5 jan. 2016. Disponível em: <https://www.fujipress.jp/ijat/au/ijate001000010004>.

OLIVEIRA, J. F. G.; BOTTENE, A. C.; FRANÇA, T. V. A novel dressing technique for texturing of ground surfaces. CIRP Annals - Manufacturing Technology, v. 59, n. 1, p. 361-364, 2010.

OLIVEIRA, J. F. G.; DORNFELD, D. A. Application of AE contact sensing in reliable grinding monitoring. CIRP Annals - Manufacturing Technology, v. 50, n. 1, p. 217220, 2001.

RABIEY, M. Dry Grinding with CBN Wheels, The Effect of Structuring. 2010. University of Stuttgart, 2010.

ROWE, W. B. Principles of Modern Grinding Technology. [s.I: s.n.]

SALLES B. B., CARDOSO R. C. , DUARTE D. (2015) Crank-Drive with Bearings Having MicroRamp Structures of Asymmetric Form, US 2015/0204377 A1. Disponível em:<https://patentimages.storage.googleapis.com/5e/f9/fe/328167e8ad1069/US2015 0204377A1.pdf>

SILVA, E. J.; KIRSCH, B.; BOTTENE, A. C.; SIMON, A.; AURICH, J. C.; OLIVEIRA, J. F. G. Manufacturing of structured surfaces via grinding. Journal of Materials Processing Technology, v. 243, p. 170-183, 2017. Disponível em: <http://linkinghub.elsevier.com/retrieve/pii/S0924013616304526>.

SILVA, E. J.; MARCOS, G. P.; VENTER, G. S.; BOTTENE, A. C.; OLIVEIRA, J. F. G. de; RODRIGUES, C. A. Development of a patterning system for vitrified CBN wheels based on modal analysis. CIRP Annals, p. 1-5, abr. 2018. Disponível em: 
<https://doi.org/10.1016/j.cirp.2018.04.076>.

SILVA, E. J.; BOTTENE, A. C.; DE OLIVEIRA, J. F. G.; ATOATTE, A.; RODRIGUES, A. de S. Grinding process for profiled texturing. CIRP Annals - Manufacturing Technology, v. 65, n. 1, p. 337-340, 2016.

SILVA, E. J.; OLIVEIRA, J. F. G. De; SALLES, B. B.; CARDOSO, R. S.; REIS, V. R. A. Strategies for production of parts textured by grinding using patterned wheels. CIRP Annals - Manufacturing Technology, v. 62, n. 1, p. 355-358, 2013.

STȨPIEŃ, P. Regular Surface Texture Generated by Special Grinding Process. Journal of Manufacturing Science and Engineering, v. 131, n. 1, p. 11015, 2009. Disponível em: $<$ http://manufacturingscience. asmedigitalcollection .asme.org/article. aspx ?articleid=1 468485>.

STEPIÉN, P.; SZAFARCZYK, M. Generation of Regular Patterns on Ground Surfaces. CIRP Annals - Manufacturing Technology, v. 38, n. 1, p. 561-566, 1989.

VILHENA, L. M.; SEDLAČEK, M.; PODGORNIK, B.; VIŽINTIN, J.; BABNIK, A.; MOŽINA, J. Surface texturing by pulsed Nd:YAG laser. Tribology International, v. 42, n. 10, p. 1496-1504, 2009.

VLĂDESCU, S. C.; OLVER, A. V.; PEGG, I. G.; REDDYHOFF, T. Combined friction and wear reduction in a reciprocating contact through laser surface texturing. Wear, $v$. 358-359, p. 51-61, 2016.

WANG, F.; ZHANG, X.; WANG, L.; JIANG, Y.; WEI, C.; ZHAO, Y. Pyramidal texturing of silicon surface via inorganic-organic hybrid alkaline liquor for heterojunction solar cells. Journal of Power Sources, v. 293, p. 698-705, 2015. Disponível em: <http://dx.doi.org/10.1016/j.jpowsour.2015.05.124>.

ZHANG, H.; QIN, L. G.; HUA, M.; DONG, G. N.; CHIN, K. S. A tribological study of the petaloid surface texturing for Co-Cr-Mo alloy artificial joints. Applied Surface Science, v. 332, p. 557-564, 2015. Disponível em: $<$ http://dx.doi.org/10.1016/j.apsusc.2015.01.215>. 